\title{
Particulate Emission Abatement \\ for Krakow Boilerhouses
}

\author{
Final Report
}

September 29, 1998

Prepared for:

Federal Energy Technology Center

U.S. Department of Energy

P.O. Box 10940

Pittsburgh, PA 15236

DOE Project Managers:

Mr. Douglas F. Gyorke

Dr. Joanna M. Livengood

Mr. Richard E. Hucko

Mr. Douglas M. Jewell

Prepared by:

LSR Technologies, Inc. 898 Main Street

Acton, MA 01720

\section{Contributors:}

Bruce H. Easom

Leo A. Smolensky

S. Ronald Wysk

Jan Surowka

Miroslaw Litke

Jacek Ginter 


\section{Disclaimer}

This report was prepared as an account of work sponsored by an agency of the United States Government. Neither the United States Government nor any agency thereof, nor any of their employees, makes any warranty, express or implied, or assumes any legal liability or responsibility for the accuracy, completeness, or usefulness of any information, apparatus, product, or process disclosed, or represents that its use would not infringe privately owned rights. Reference herein to any specific commercial product, process, or service by trade name, trademark, manufacturer, or otherwise does not necessarily constitute or imply its endorsement, recommendation, or favoring by the United States Government or any agency thereof. The views and opinions of authors expressed herein do not necessarily state or reflect those of the United States Government or any agency thereof. 
Table of Contents

Page

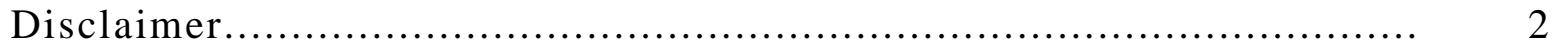

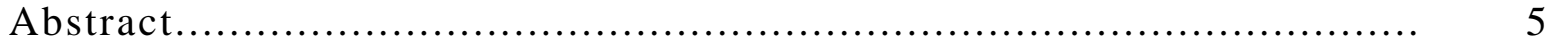

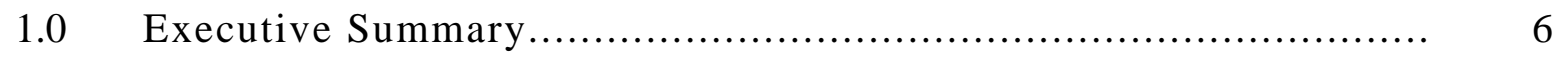

2.0 Phase 1 - Infrastructure Studies......................................... 9

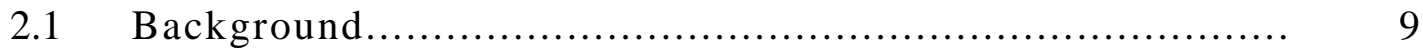

2.2 Accomplishments in Phase I.................................... 11

2.2.1 Evaluation of Polish Manufacturers............................ 12

2.2.2 Business Planning....................................... 13

2.2.3 Other Phase I Accomplishments............................ 15

3.0 Phase II - Commercial Implementation................................ 17

3.1 Prototype Demonstration...................................... 17

3.2 Other Commercial Installations in Krakow............................ 20

3.3 Other Core Separator Units Installed in Poland........................ 26

3.4 Effect on Emission Reductions.................................. 34

3.5 Core Separator Marketing Efforts in Poland.......................... 35

3.6 Award and Citations............................................. 35

3.7 Modernization of Manufacturing................................. 36

4.0 Difficulties/Problems Encountered During this Project........................ 43

$5.0 \quad$ Summary \& Conclusions................................................ 45

Acknowledgment......................................................... 46

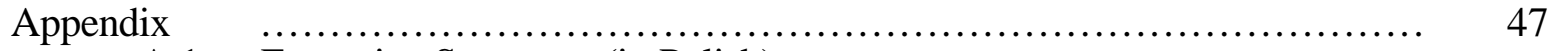

A.1 Executive Summary (in Polish)

A.2 Polish Environmental Leadership Award

A.3 Compliance Test Reports

A.4 Core Separator Technical Paper 


\section{List of Figures \& Tables}

Page

Figure 1. Emission Data for WR-5 Boiler ARMATURA Plant........................ 18

Figure 2. ARMATURA Installation............................................. 19

Figure 3. ARMATURA Core Separator....................................... 19

Figure 4. Emission Data for WCO-80 Boiler MPK Boilerhouse Unit \#1 ............. 21

Figure 5. Emission Data for WCO-80 Boiler MPK Boilerhouse Unit \#2............. 22

Figure 6. Emission Data for WCO-80 Boiler MPK Boilerhouse Unit \#3............. 23

Figure 7. MPK Installation In Construction.............................................. 24

Figure 8. MPK Emission Test Equipment....................................... 24

Figure 9. MPK Installation During Commissioning .................................. 25

Figure 10. Completed MPK Installation............................................... 25

Figure 11. Budostal Krakow Core Separator................................... 29

Figure 12. Budostal Core Separator Layout....................................... 29

Figure 13. Core Separator Installation - Oborniki................................... 30

Figure 14. Side View - Oborniki Core Separator................................ 30

Figure 15. Stack Condition at Knurow Prior to Core Separator...................... 31

Figure 16. Core Separator Installation - Knurow................................... 31

Figure 17. Structural Steel Installation - FIAT AUTOPOLAND....................... 32

Figure 18. Core Separator Module Installation - FIAT AUTOPOLAND................ 32

Figure 19. Core Separator Near Complete - FIAT AUTOPOLAND..................... 33

Figure 20. Completed Core Separator - FIAT AUTOPOLAND........................ 33

Figure 21. EcoInstal Exhibit - EcoPol Trade Show...................................... 38

Figure 22. Core Separator Exhibit - EcoPol Trade Show............................... 38

Figure 23. Polish/U.S. Exhibit - EcoPol Trade Show.................................. 39

Figure 24. Equipment Display - EcoPol Trade Show................................... 39

Figure 25. Core Separator Production at EcoInstal................................... $\quad 40$

Figure 26. Production Sequence at EcoInstal........................................ 40

Figure 27. Initial Forming of Core Separator Module............................... 41

Figure 28. Quality Control Department - EcoInstal...................................... 41

Figure 29. Completed Core Separator Modules - EcoInstal............................ 42

Figure 30. Equipment Being Shipped from EcoInstal................................. 42

Table 1. $\quad$ Core Separators Produced by EcoInstal................................... 28 
DE-FC22-94PC94111

\begin{abstract}
A U.S./Polish Bilateral Steering Committee (BSC) and the Department of Energy (DOE) selected LSR Technologies, Inc. as a contractor to participate in the Krakow Clean Fuels and Energy Efficiency Program. The objective of this program was the formation of business ventures between U.S. and Polish firms to provide equipment and services to reduce air emissions in the city of Krakow. A cooperative agreement was entered into by DOE and LSR to begin work in April 1994 involving implementation of particulate control technology called a Core Separator ${ }^{\mathrm{TM}}$ for coal-fueled boilerhouses in the city. The major work tasks included: (1) conducting a market analysis, (2) completion of a formal marketing plan, (3) obtaining patent protection within Poland, (4) selecting a manufacturing partner, and (5) completing a demonstration unit and commercial installations. In addition to work performed by LSR Technologies, key contributors to this project were (1) the Polish Foundation for Energy Efficiency (FEWE), a non-profit consulting organization specializing in energy and environmental-related technologies, and (2) EcoInstal, a privately held Polish company serving the air pollution control market. As the project concluded in late 1998, five (5) Core Separator ${ }^{\mathrm{TM}}$ installations had been implemented in the city of Krakow, while about forty (40) others were completed in other regions of Poland.
\end{abstract}


DE-FC22-94PC94111

\subsection{Executive Summary}

Environmental cleanup and pollution control have been considered foremost national priorities in Poland during the post-communist era. More than four decades of centralized planning has produced severe contamination of air, water, and soil throughout the country and a resulting deterioration of public health. The government of Poland has begun to implement environmental controls in order to reverse this condition. One of the targets of these controls has been the Polish coal industry, which in 1990 represented about $80 \%$ of primary energy production. Coal utilization in Poland has been very inefficient with as much as 2 to 3 times more energy consumption as western Europe per unit of gross domestic product (GDP).

As part of the Krakow Clean Fuels and Energy Efficiency Program, LSR Technologies, Inc. was selected by a U.S./Polish Bilateral Steering Committee to participate in one of the five (5) pilot project areas. The chosen pilot area focused on reducing particulate emissions from boilerhouses firing coal and coke, using new dust collector technology called a Core Separator ${ }^{\mathrm{TM}}$. It had been postulated that the Core Separator ${ }^{\mathrm{TM}}$, a cost-effective device with much higher efficiency than multicyclones, would be an excellent match for the highly fragmented boilerhouse emitters in Krakow. In the early 1990s, the city had about 1,300 boilerhouses containing about 2,900 heating boilers. And, while many of the older boilerhouses have since been retired, there remains in Krakow a sizeable boiler population that is still a primary source of particulate air emissions.

A cost-shared Cooperative Agreement was entered into by LSR and DOE in 1994 to provide equipment and services to reduce emissions from these sources. A two-phase project was created by dividing the work tasks into two successive and well-defined structures. Phase I consisted of infrastructure studies including: (1) completion of a business plan and market strategy, (2) evaluation and selection of a manufacturing partner to service the anticipated market, and (3) insuring that adequate financing and cost-share commitments were in place for the initial installations. To complete this effort, the Polish Foundation for Energy Efficiency (also known as 
DE-FC22-94PC94111

FEWE) was contracted by LSR to assist in the overall planning and execution of work. At the completion of the first work phase, the Polish firm, EcoInstal, was also selected as the principal business partner for LSR.

The Phase II effort involved a more substantial financial commitment to essentially implement the technology in boilerhouse applications. A demonstration site for the first Core Separator $^{\mathrm{TM}}$ was contracted with Krakowskie Zaklady Armatur, as part of a dust collector upgrade on a WR-5 heating boiler. Four (4) additional Core Separator units were installed at other sites in Krakow. In each, dust collector efficiency increased from $75-80 \%$ to the range $94-97 \%$. Emission rates for dust particles correspondingly decreased to less than 20 grams/GJ (0.05 lb/MBTU), which approaches that of more costly devices such as ESPs and fabric filters. In parallel to the installations sited in Krakow, forty (40) additional Core Separator units were placed in operation in other regions of Poland, including many in nearby Silesia which is a source of air pollution in Krakow.

To accommodate the demand for Core Separator units in Poland, the manufacturing capability of EcoInstal was expanded substantially. The process of upgrading the manufacturing process involved a major collaborative effort that included the following tasks: (1) development of modular designs using CAD/CAM techniques, (2) technology transfer adapted to Polish metal sizes and specifications, (3) developing fixtures to standardize component parts, (4) the acquisition of new manufacturing equipment, and (5) extensive training for production workers. As a result of these improvements, EcoInstal is recognized today as a respected air pollution equipment manufacturer that can compete with just about any metalworking company with respect to cost and product quality.

During the course of this project, both LSR and EcoInstal received prestigious awards that were each related to the Core Separator. In 1996, LSR won the R\&D 100 Award given annually to the best technology-based new products of the year worldwide. In 1997, EcoInstal won the Polish Environmental Leadership Award given by the Minister of the Environment for exceptional 
contributions toward pollution control.

This project has been very successful in achieving goals originally set forth by the U.S./Polish steering committee. The project has been able to claim the following accomplishments consistent with those goals:

- Creation of a mutually beneficial business venture between a Polish and U.S. firm which will sustain itself on a continuing basis

- Installation of five (5) Core Separator installations in Krakow as well as many other nearby units all of which improve air quality in this historic city

- Installation of forty-five (45) Core Separator installations throughout Poland with a combined capacity of 1.7 million $\mathrm{M}^{3} / \mathrm{h}(1.0$ million acfm)

- A reduction of particulate emissions in Krakow of more than 115 metric tons per year and a reduction of more than 2,150 metric tons per year throughout Poland

- Introduction of a new technology to a Polish firm, enabling that firm to grow substantially and triple its employee work force

- An added benefit to the Polish firm of exporting equipment out of the country, creating jobs for the local economy, while having a positive effect on the Polish trade balance. 
DE-FC22-94PC94111

\subsection{Phase 1 -- Infrastructure Studies}

\subsection{Background}

The Krakow Clean Fossil Fuels and Energy Efficiency Program was originally evolved from the Support for Eastern European Democracy (SEED) Act of 1989. Through funding from the Agency for International Development (AID) and the Department of Energy (DOE), the program was created to reduce air pollution in the City of Krakow from about 1,300 boiler houses. In 1992 when the program was initiated, these boiler houses contained more than 2,900 boilers that provide heat for industrial, commercial, and residential use. The 2,900 boilers represented a combined input capacity of approximately 1,000 MW(t), which is substantial as it compares to 200 MW(t) capacity for 100,000 room heating stoves in Krakow. More than $75 \%$ were coal- or cokefired units and released an estimated 1,400 Tonnes/year of particulate matter. Since the facilities contain short (low) stacks, combustion products enter the atmosphere close to ground level. They are therefore referred to as "low emission sources."

These low emission sources are the primary source of particulate air pollution in the City of Krakow. The uncontrolled boilers, those with no control equipment, produce about $75 \%$ of the total particulate emissions from coal- or coke-fired boilers. The remaining boilers which are generally larger in capacity employ cyclonic collectors and produce $25 \%$ of the particulate emissions. There presently are no provisions in place to control fine particulate matter, often referred to as $\mathrm{PM}_{10}$, which is most hazardous to human health.

This project addresses Reduction of Emissions from Boiler Houses Firing Coal and Coke, one of the five pilot projects identified by the U.S./Polish Bilateral Steering Committee. This target application is significant for the following reasons:

- Air quality improvements are needed both to protect the health of citizens of Krakow and to preserve the city's historic monuments. 
- The Core Separator developed by LSR is a new technology and a cost-effective solution to the particulate emission problem in uncontrolled boilers. An important feature is its ability to control $\mathrm{PM}_{10}$ particulate matter, which consists of dust particles below 10 microns in diameter.

- The efficiency, ease of maintenance, and low cost compared to electrostatic precipitators or fabric filters, make it practical for large numbers of low capacity boilers. It can also be used to replace the existing cyclone collectors during normal boiler overhaul periods. Since dust emissions resulting from such replacement would be 4 to 6 times lower, particulate levels emitted would be comparable to that of EU countries.

It is significant that since 1992 there has been a major reduction in the number of coal- and coke-fired boilers located in Krakow. This reduction was the result of several factors including (1) extensions in the district heating system, (2) fuel conversions to natural gas, and (3) retirement for economic reasons. The reduction process was also accelerated by the gradual deregulation of coal prices and loss of coal subsidies during the 1990's. Nonetheless, even with this large reduction in the number of boiler houses, there is still a sufficient number of operating boilers to justify investment in and cost recovery of a business venture related to emissions reduction.

A team was formed to provide the necessary technical, manufacturing, and infrastructure knowledge to make this project economically viable. LSR Technologies, Inc., a small business located in Acton, Massachusetts and the developer of the technology and holder of its patent rights, has been the primary contractor for this work. LSR has sold Core Separators in the U.S. and Europe and has been leading the team to commercialize this technology in Poland, starting with penetration of the market opportunity in Krakow. The company's overall objective in this project has been to make a positive impact on the coal-fired boiler market in Krakow, then eventually expand to other cities in Poland, and ultimately elsewhere in Europe. The Core Separator had been 
DE-FC22-94PC94111

developed under DOE-sponsored research and was cited as one of its successful technologies.

Another team member and subcontractor for this work was the Polish Foundation for Energy Efficiency (FEWE), which has offices in Krakow, Katowice, and Warsaw. FEWE had been a contractor to both DOE and EPA, and has extensive knowledge of energy usage in Poland and its environmental impact. Because of its familiarity with the industrial base in Southern Poland, FEWE played a major role in identifying and selecting a manufacturing partner.

\subsection{Accomplishments in Phase I}

A Commercialization Plan submitted to DOE and the BSC by LSR was used throughout this project and has largely remained intact. One significant change or deviation from this plan involved a decision to identify and select a Polish manufacturing company for partnership rather than to establish a grass roots organization. This alternative became apparent during early infrastructure studies of Polish business practices. Thus, the major efforts during this period included the following:

- $\quad$ Conduct an Evaluation of Potential Manufacturing Companies

- Solicit Proposals for Collaboration

- Select the Most Promising Candidate

- Enter a Formal Cooperative Agreement

- $\quad$ Complete a Detailed Business Plan

- Evaluate Krakow's Boiler Market

- Assess Polish Environmental Regulations

- Create a Plan for a Joint Venture Company or Licensing 
DE-FC22-94PC94111

\subsubsection{Evaluation of Polish Manufacturers}

LSR efforts to identify a suitable manufacturing partner concentrated exclusively on companies located in or near the City of Krakow. About 12 companies were contacted and visits were made to each of these. Negotiations were conducted with three of these companies, in order to determine the level of interest and commitments. Regrettably, none of these companies were able to make significant financial commitments to this project. Each was interested in a form of licensing that required minimal cost and no dilution of their equity.

LSR also received unsolicited proposals from manufacturers in other cities in Poland. One substantial boiler company located near Katowice, and EcoInstal based in Koscian, each presented stronger proposals to LSR than any of the Krakow companies. EcoInstal's proposal clearly represented the strongest financial commitment, and became LSR's first choice. The selection of EcoInstal took place only after discussions and concurrence with DOE personnel.

EcoInstal is a privately held company with a single owner in Poznan. The company was founded in 1985 when communism was still deeply entrenched in Poland. By 1989 when the Polish government changed, the company had grown to about 30 employees. Its principal products include air pollution control products, including cyclone collectors and fabric filters. It also produces several types of solids conveyers and an excellent mechanical air lock. It sells and markets its products throughout Poland, but has a particularly strong presence in the central region and in Silesia. EcoInstal has always been a very entrepreneurial company and has a western style of management.

LSR recommended to DOE that EcoInstal be selected for partnership in this project. On November 11, 1994 a Cooperative Agreement was signed by LSR and EcoInstal to produce Core Separators for the Polish and Central European market. The agreement included a commitment by EcoInstal to cost share for the bulk of work performed in the second budget period. 
DE-FC22-94PC94111

\subsubsection{Business Planning}

A detailed business plan was prepared by LSR with significant input from FEWE. The business plan was submitted to DOE in November 1994. The business planning evolved around the establishment of a joint venture company recognizing the capabilities of both LSR and EcoInstal. In 1994, EcoInstal's capabilities for producing high volumes of equipment were very limited. While it had an excellent work force and good management, its equipment was largely outdated and obsolete by U.S. standards. This was typical of many manufacturers in Poland. Thus, new fabrication equipment would be needed and will make the joint venture company more competitive, both in Poland and internationally. A summary of this plan follows.

The business venture is to be created in Poland for the purpose of producing and selling pollution control equipment in this Central European nation. The joint venture would be owned by LSR Technologies, Inc. and EcoInstal, a supplier of air pollution control equipment based near the City of Poznan. The new venture is being established to market, sell, manufacture, and install pollution control equipment within the industrial sector of Poland and also for the export market.

Decades of central government planning have left a situation of near environmental disaster in Poland, particularly in the southern region where low-grade coal is used extensively for heat and electricity. With severe public health problems and a lower life expectancy today than 20 years ago, there is an urgent need to reduce particulate air emissions in this region. For this reason, the World Bank and several ecological relief organizations have set aside funds for the environmental restoration of this area. The U.S. AID Program in cooperation with the Department of Energy is also providing assistance to the area around historic Krakow, which has been hit especially hard by environmental neglect.

While Poland, the Czech Republic, and Hungary will be key markets for the joint venture, the City of Krakow will be the focal point for early implementation of pollution control projects. Krakow, the third largest city in Poland, is located adjacent to the Upper Silesian coal basin. The 
DE-FC22-94PC94111

city contains thousands of historic sites, and is listed by UNESCO as one of the 12 most important cultural centers in the world. The city also has close to 1,000 boiler houses containing nearly 2,000 boilers to provide heat for industrial, commercial, and residential use. The 2,000 boilers have a combined input capacity of nearly 1,000 MW(t), which is substantial as it compares to 200 MW(t) capacity for 100,000 room heating stoves in Krakow. More than $75 \%$ of these are coal- or coke-fired units and release about 1,000 Tonnes/year of particulate matter. These sources and others represent a potential market for particulate control equipment of about $\$ 200$ million annually in all of Poland.

Low emission sources are the primary source of particulate air pollution in Krakow. Uncontrolled boilers, those with no control equipment, produce about $75 \%$ of the total particulate emissions from coal- or coke-fired boilers. The remaining boilers, which are generally larger in capacity, employ cyclonic collectors and produce $25 \%$ of the particulate emissions. There presently are no provisions in place to adequately control fine particulate matter, which is most hazardous to human health.

The new venture will be a major supplier of emission control equipment for boiler houses firing coal and coke, a significant undertaking for the following reasons:

(1) Air quality improvements are needed both to protect the health of the citizens of Krakow and to preserve the city's historic structures and monuments.

(2) Similar air quality improvements are needed in other parts of Poland and Central Europe.

(3) The new venture intends to market the Core Separator, a high efficiency device for particulate control. 
DE-FC22-94PC94111

(4) The technology can also reduce particulate emissions from the boilers currently controlled with cyclone dust collectors.

In 1990 Poland enacted its own version of the Clean Air Act. Since that time, the market has been ready to accept the challenge presented. The establishment of a new business in a soonto-be expanding segment of the air pollution industry will have the following advantages:

- Poland has the largest and fastest growing homogeneous consumer market in Central Europe and the fastest growing economy in all of Europe.

- The new product is entering the fastest growing segment of the air pollution control industry.

- The potential market for this type of equipment in Poland is substantial and American technology is highly respected.

- With the advanced design which this new product represents, the new technology could capture $10 \%$ of the market served within five years, which is $\$ 10$ million.

- Profitability is assured by the market requirements for this product, the proven experience of the founding group, and the low cost manufacturing to be employed.

\subsubsection{Other Phase I Accomplishments}

LSR together with EcoInstal have also performed several other functions which are complimentary and supportive of the project in Krakow. A summary of these accomplishments are cited below. It should be noted that many of these accomplishments were not performed with DOE financing. 
DE-FC22-94PC94111

- A Core Separator unit was sold, built, and installed to treat flue gas from a WR2.5 boiler in Oborniki. This unit went into operation in April 1995, was tested by an independent organization, and was found to have dust emissions below $50 \mathrm{mg} / \mathrm{M}^{3}$.

- A Core Separator unit was also sold and installed an a fluidized bed boiler used for heating and located near Tarnow. This unit has been operating successfully since April 1995 and also tested satisfactorily even at low load (off-design) conditions.

- A Core Separator unit was sold, built, and shipped to a foreign customer for a stokerfed boiler in Mauritius. This unit, also built by EcoInstal, was started up in 1996.

- A Core Separator patent application was prepared and filed in Poland, Germany, Slovakia, and the Czech Republic.

- Purchase orders were received for two new Core Separator units, one for a WR10 boiler in Gliwice and a second for a metal smelter near Lubin.

- Letters of intent were received from three Krakow companies for five Core Separator units for boiler applications. These units would be eligible for DOE financing.

- A letter of intent was received for four (4) new Core Separator units for boiler applications. These units are to be installed in other regions of Poland.

- EcoInstal and LSR have also conducted broad marketing activities in Krakow and elsewhere including the preparation of product brochures, visits to sites to promote the technology, exhibits at trade fairs, and presentation of technical papers at conferences. 
DE-FC22-94PC94111

\subsection{Phase II - Commercial Implementation}

\subsection{Prototype Demonstration}

The first major task in Phase II was the installation of a demonstration unit in Krakow. The site selected was that of Krakowskie Zaklady Armatur, a mid-sized manufacturer of household fixtures. Armatura has a well-maintained heating plant with several hot water heating boilers providing heat for facility needs. A Core Separator ${ }^{\mathrm{TM}}$ system was contracted from EcoInstal to replace a multicyclone collector that had been in operation for several years on a WR-5 boiler.

The Core Separator ${ }^{\mathrm{TM}}$ at ARMATURA went into operation in January 1996 during one of the coldest winters in recent years. Initially, some moisture problems were experienced from condensation inside the collector. The condensation resulted from the unusually low temperatures, and caused intermittent plugging in the ash removal system. The solution to this problem was the addition of insulation to outside surfaces in order to remain above the dewpoint.

Particulate emissions and efficiency of the Core Separator ${ }^{\mathrm{TM}}$ was measured by the Polish testing firm Emitor, located in Opole. The particle concentration measured at the boiler outlet was $846 \mathrm{mg} / \mathrm{Nm}^{3}$ and at the dust collector outlet was $34 \mathrm{mg} / \mathrm{Nm}^{3}$, representing a removal efficiency of 95.4\%. The outlet emission rate was less than 20 grams/GJ, which is well below the Polish standard for grate-type boilers. A summary of the data collected during acceptance testing is shown in Figure 1. The full test report can also be found in the Appendix.

The precleaning cyclone for ARMATURA was actually located inside the boilerhouse, and the gas temperature drop through this device was minimal. However, the temperature drop through the Core Separator unit was about $70^{\circ} \mathrm{C}$, as this unit was located outdoors just before the stack. This data taken during the winter of 1996 clearly shows substantial convective cooling and the need for insulation of the dust collector. Figures 2 and 3 are photographs of the installation at ARMATURA. 
Figure 1.

Emission Data for WR-5 Boiler

ARMATURA Plant

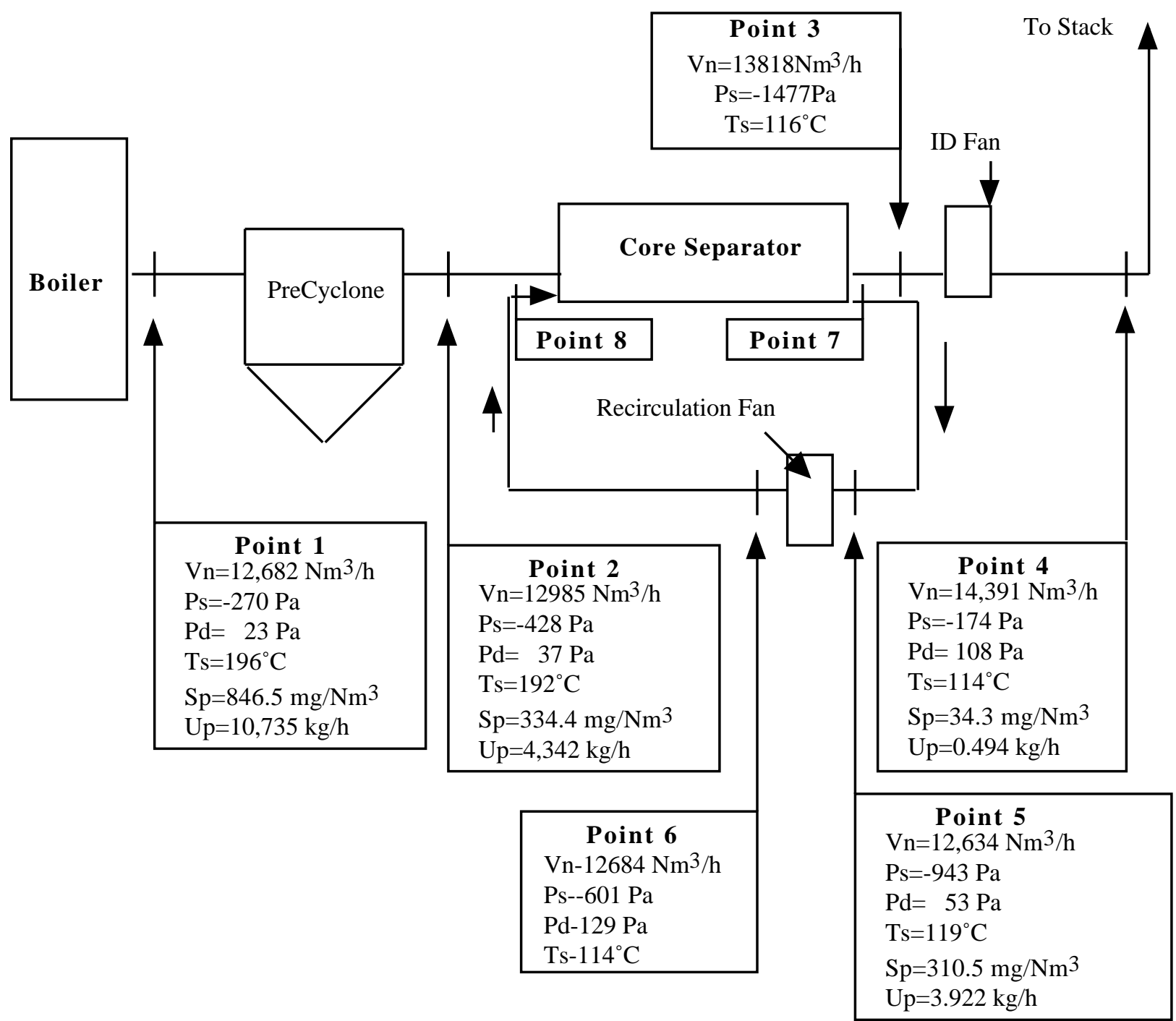

\begin{tabular}{|c|c|c|c|c|c|c|}
\hline Parameter & $\begin{array}{c}\text { Temperature } \\
\text { Flue Gas }\end{array}$ & $\begin{array}{c}\text { Static } \\
\text { Pressure }\end{array}$ & $\begin{array}{c}\text { Dynamic } \\
\text { Pressure }\end{array}$ & $\begin{array}{c}\text { Gas Flow } \\
\text { Rate }\end{array}$ & $\begin{array}{c}\text { Dust Con- } \\
\text { centration }\end{array}$ & $\begin{array}{c}\text { Dust } \\
\text { Content }\end{array}$ \\
\cline { 2 - 7 } & ${ }^{\circ} \mathrm{C}$ & $\mathrm{Pa}$ & $\mathrm{Pa}$ & $\mathrm{Nm} 3 / \mathrm{h}$ & $\mathrm{mg} / \mathrm{Nm} 3$ & $\mathrm{~kg} / \mathrm{h}$ \\
\hline Point 1 & 196 & -270 & 23 & 12682 & 846,5 & 10,735 \\
\hline Point 2 & 192 & -428 & 37 & 12985 & 334,4 & 4,342 \\
\hline Point 3 & 116 & -1477 & 97 & 13818 & - & - \\
\hline Point 4 & 114 & -174 & 108 & 14391 & 34,3 & 0,494 \\
\hline Point 5 & 119 & -943 & 53 & 12634 & 310,5 & 3,922 \\
\hline Point 6 & 114 & -601 & 129 & 12684 & - & - \\
\hline Point 7 & 118 & -925 & - & - & - & - \\
\hline Point 8 & 116 & -851 & - & - & - & - \\
\hline
\end{tabular}




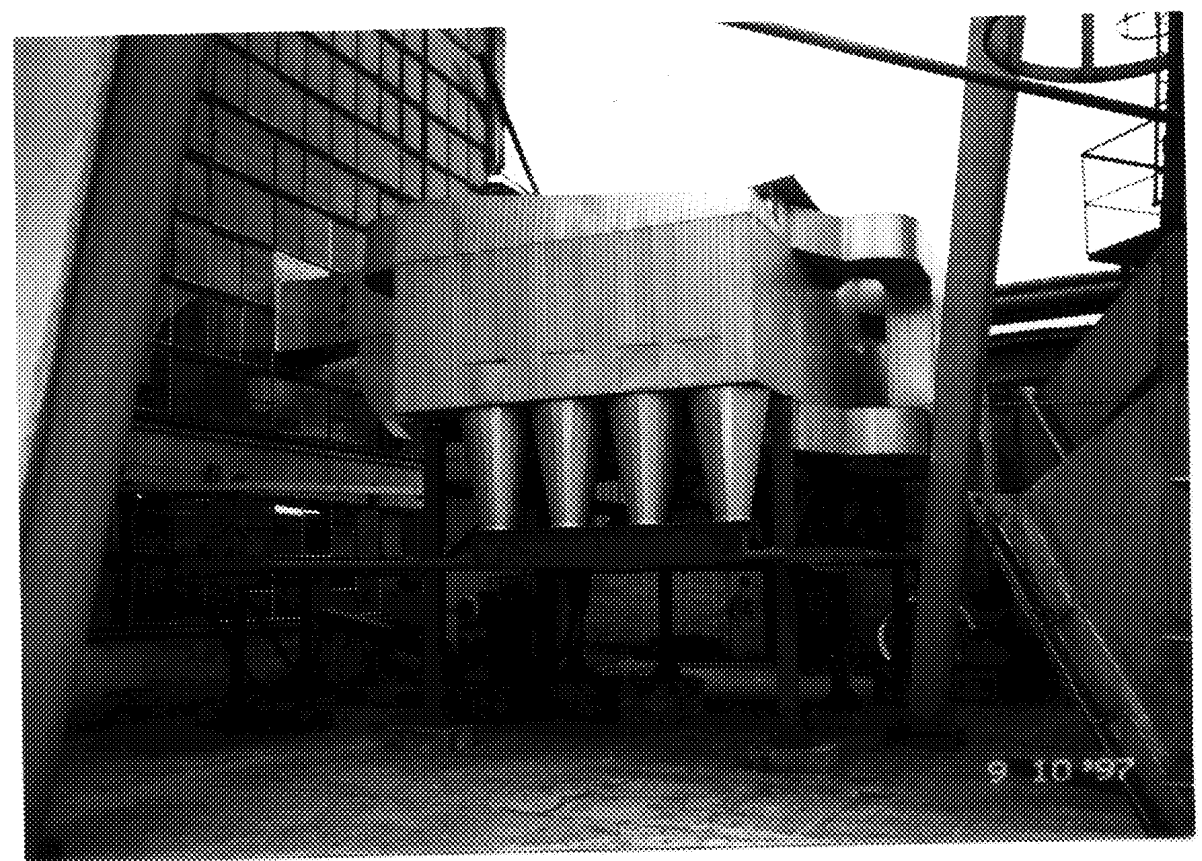

Figure 2. ARMATURA Installation

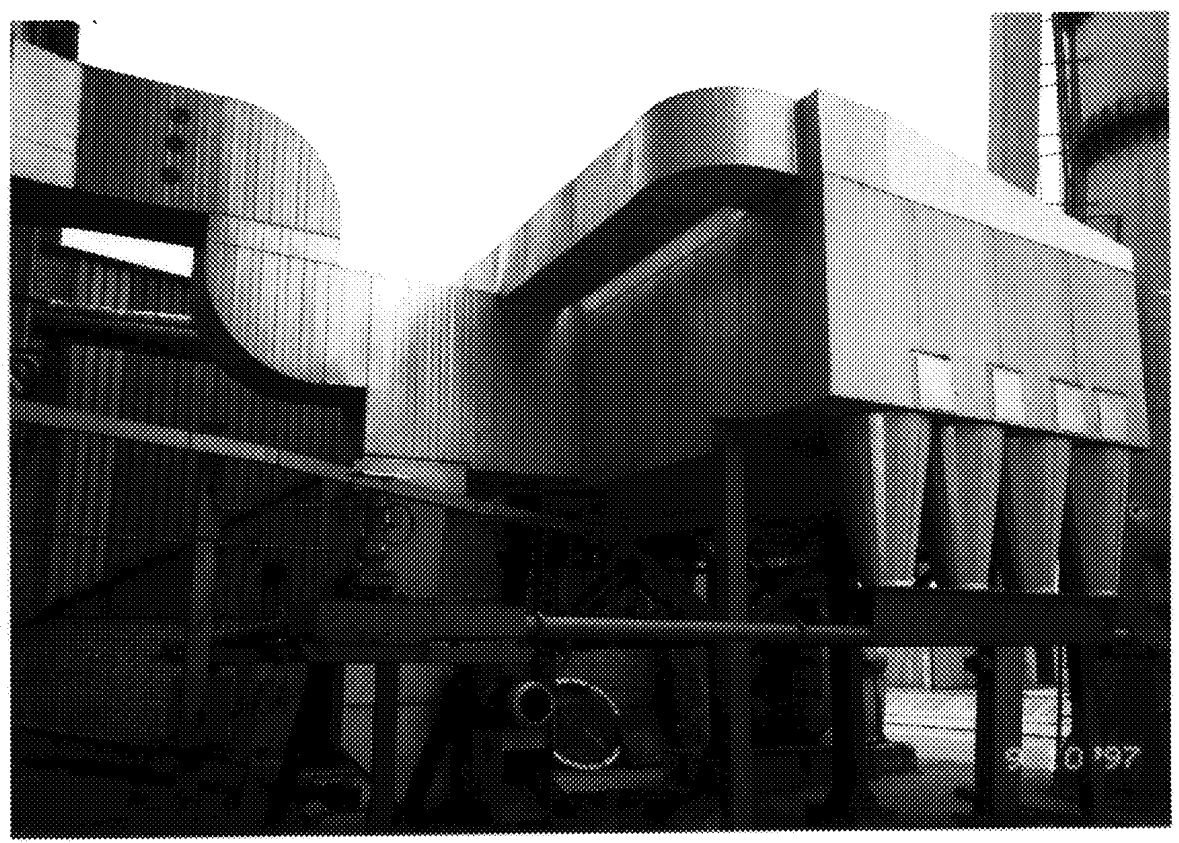

Figure 3. ARMATURA Core Separator 
DE-FC22-94PC94111

\subsection{Other Commercial Installations in Krakow}

Miejskie Przedsienbiorstwo Komunikacyjne (MPK) is the municipal transit company for the city of Krakow, operating buses and a trolley car system within city limits. MPK operates a few boilerhouses throughout its system to meet its heating needs. One of these boilerhouses was contracted to install new dust collecting equipment for three (3) type WCO-80 stoker boilers.

Three (3) Core Separator units were placed into operation in January 1996. Prior to this, no emission control equipment had been in place. The new dust collectors were located outside of the boilerhouse due to space limitations, and a roof enclosure was added to protect it from weather elements. All three (3) dust collectors were tested for particulate emissions and also for efficiency by the firm Emitor.

These units operated very smoothly from the start. Unlike the unit at ARMATURA, there was no evidence of moisture condensation. During the testing however, the measurements of collector efficiency and particle emissions showed some variation between each of the three units. It was determined that the isokinetic sampling equipment had been affected by extremely low temperatures and should be tested again. Following another set of tests, it was concluded that the Core Separator units were all performing quite satisfactorily.

A summary of data collected during acceptance testing is shown in Figures 4, 5, and 6 below. The full test reports are located in the Appendix. Outlet emissions from these units are also well below 20 gram/GJ. Figures 7-10 are photographs of the dust collectors and sampling equipment at MPK. 
Figure 4.

Emission Data for WCO-80 Boiler MPK Boilerhouse Unit \#1

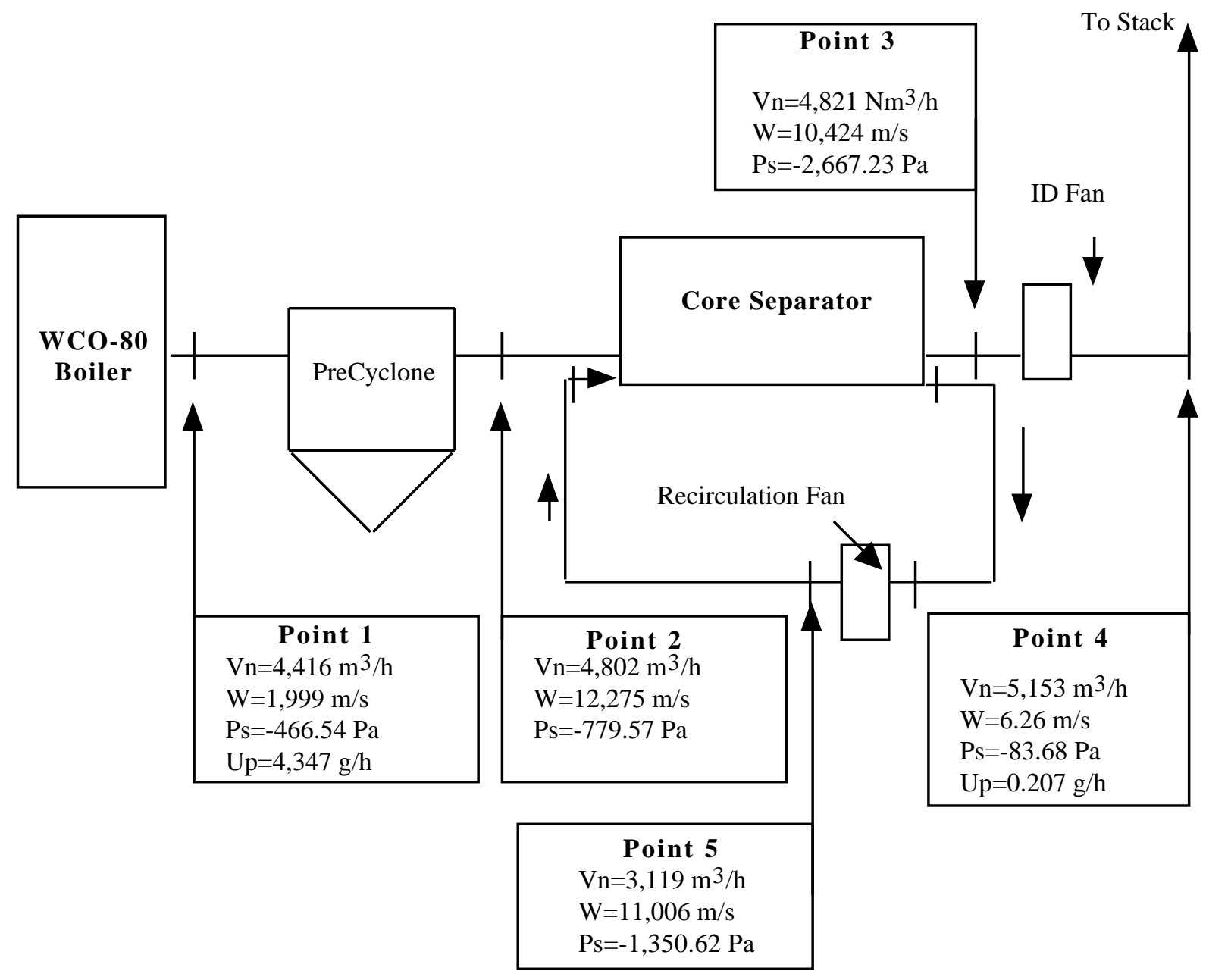


Figure 5.

Emission Data for WCO-80 Boiler

MPK Boilerhouse Unit \#2

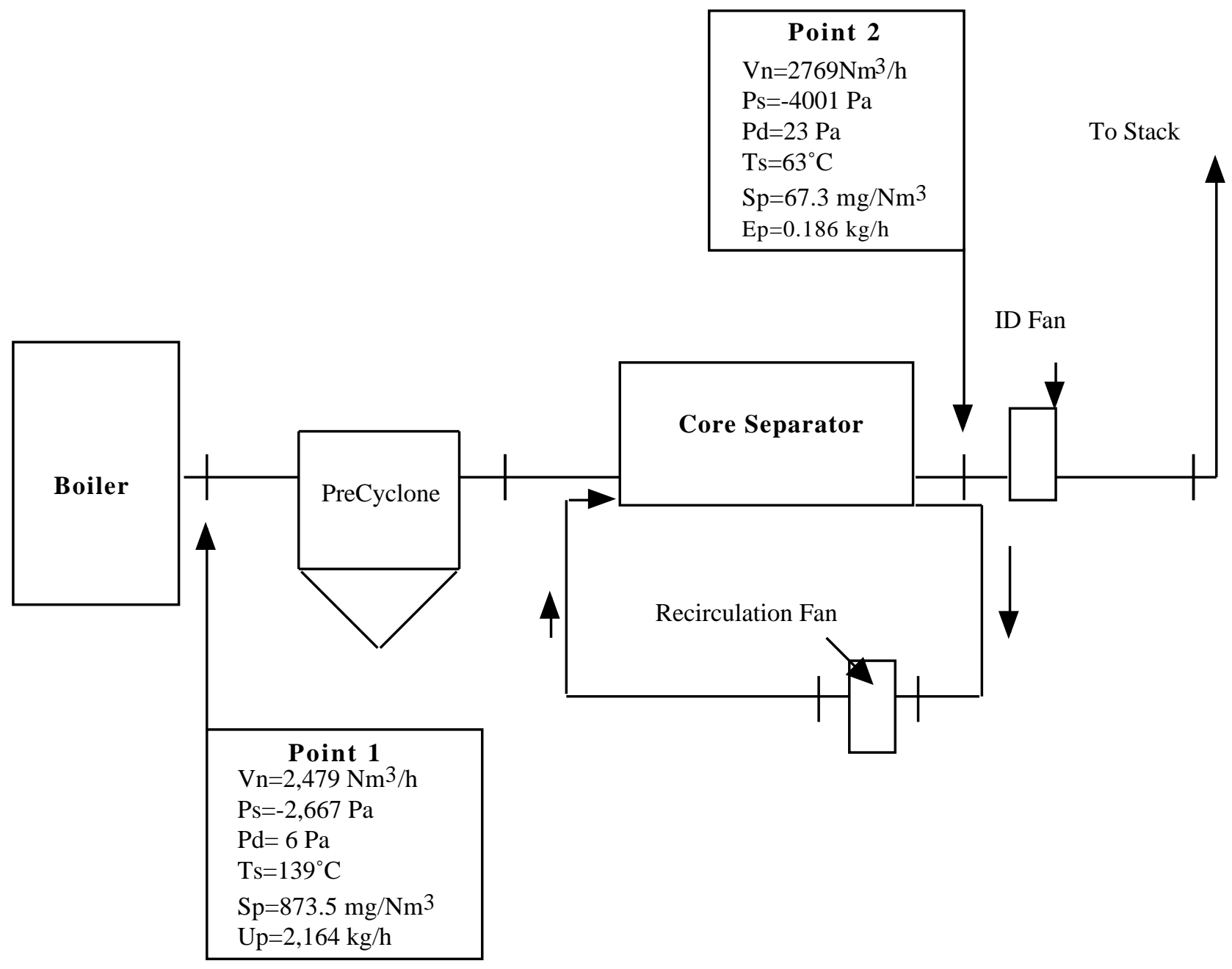

\begin{tabular}{|c|c|c|c|c|c|c|}
\hline Parameter & $\begin{array}{c}\text { Temperature } \\
\text { Flue Gas }\end{array}$ & $\begin{array}{c}\text { Static } \\
\text { Pressure }\end{array}$ & $\begin{array}{c}\text { Dynamic } \\
\text { Pressure }\end{array}$ & $\begin{array}{c}\text { Gas Flow } \\
\text { Rate }\end{array}$ & $\begin{array}{c}\text { Dust Con- } \\
\text { centration }\end{array}$ & $\begin{array}{c}\text { Dust } \\
\text { Content }\end{array}$ \\
\cline { 2 - 8 } & ${ }^{\circ} \mathrm{C}$ & $\mathrm{Pa}$ & $\mathrm{Pa}$ & $\mathrm{Nm} 3 / \mathrm{h}$ & $\mathrm{mg} / \mathrm{Nm} 3$ & $\mathrm{~kg} / \mathrm{h}$ \\
\hline \hline Point 1 & 139 & -2667 & 6 & 2479 & 873.5 & 2 \\
\hline Point 2 & 63 & -4001 & 23 & 2769 & 67.3 & 0 \\
\hline
\end{tabular}


Figure 6.

Emission Data for WCO-80 Boiler

MPK Boilerhouse Unit \#3

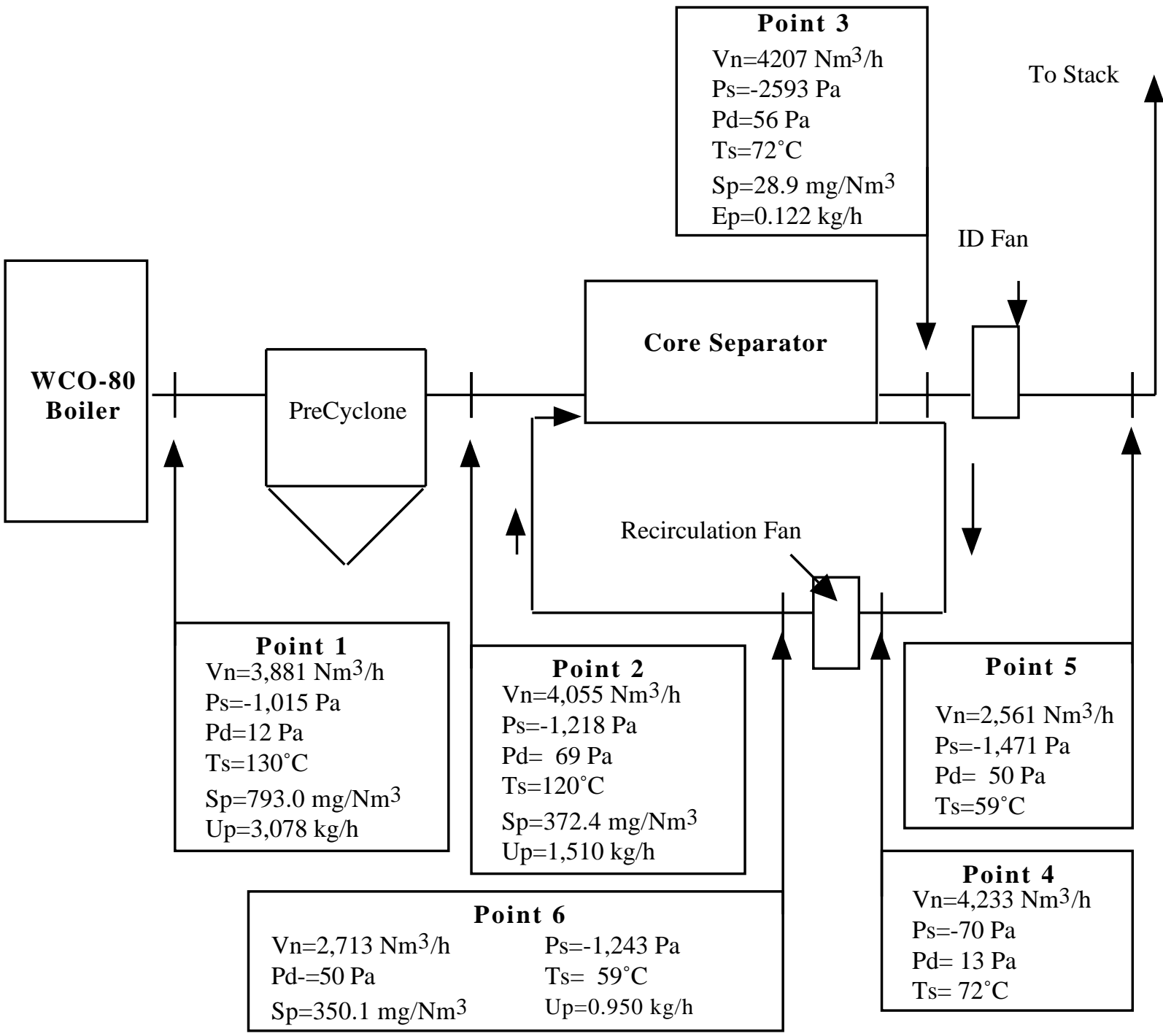

\begin{tabular}{|c|c|c|c|c|c|c|}
\hline Parameter & $\begin{array}{c}\text { Temperature } \\
\text { Flue Gas }\end{array}$ & $\begin{array}{c}\text { Static } \\
\text { Pressure }\end{array}$ & $\begin{array}{c}\text { Dynamic } \\
\text { Pressure }\end{array}$ & $\begin{array}{c}\text { Gas Flow } \\
\text { Rate }\end{array}$ & $\begin{array}{c}\text { Dust Con- } \\
\text { centration }\end{array}$ & $\begin{array}{c}\text { Dust } \\
\text { Content }\end{array}$ \\
\cline { 2 - 7 } & ${ }^{\circ} \mathrm{C}$ & $\mathrm{Pa}$ & $\mathrm{Pa}$ & $\mathrm{Nm} 3 / \mathrm{h}$ & $\mathrm{mg} / \mathrm{Nm} 3$ & $\mathrm{~kg} / \mathrm{h}$ \\
\hline \hline Point 1 & 130 & -1015 & 12 & 3881 & 793.0 & 3.078 \\
\hline Point 2 & 120 & -1218 & 69 & 4055 & 372.4 & 1.510 \\
\hline Point 3 & 72 & -2593 & 56 & 4207 & 28.9 & 0.122 \\
\hline Point 4 & 72 & -70 & 13 & 4233 & - & - \\
\hline Point 5 & 59 & -1471 & 44 & 2561 & - & - \\
\hline Point 6 & 59 & -1243 & 50 & 2713 & 350.1 & 0.95 \\
\hline
\end{tabular}




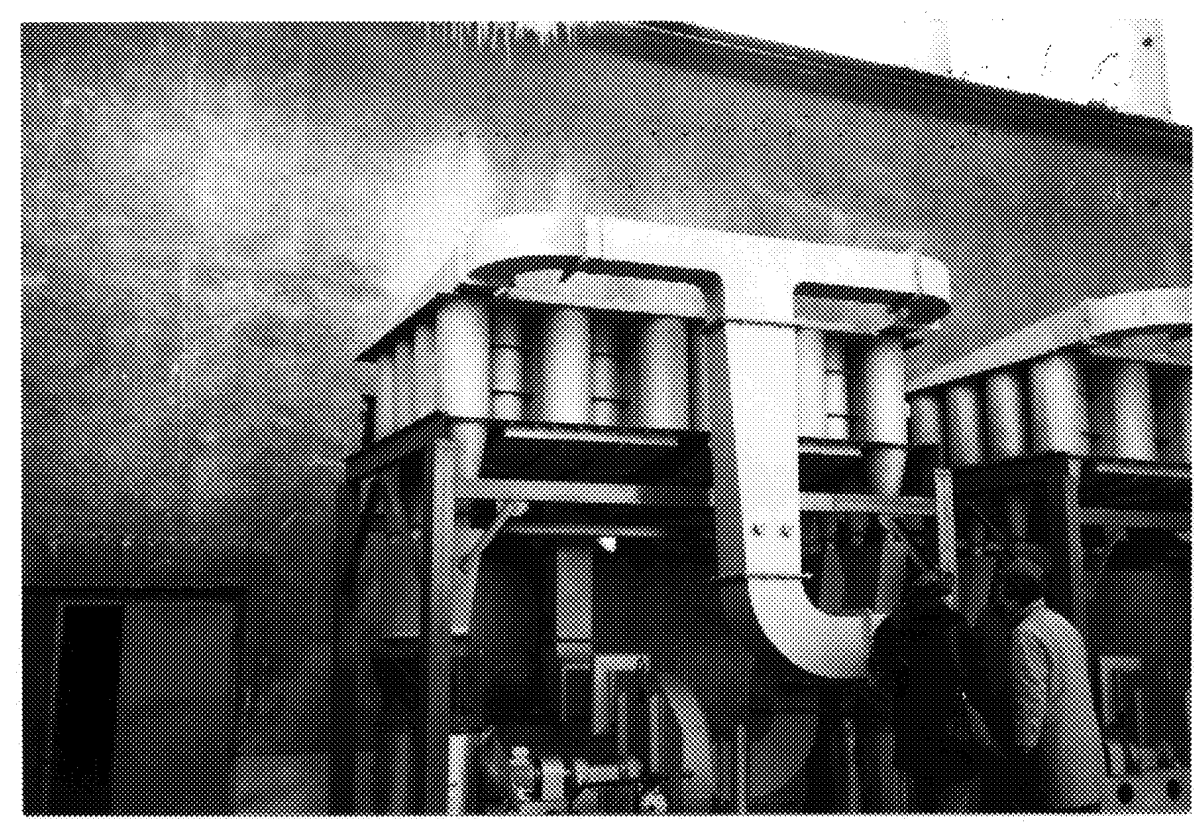

Figure 7. MPK Installation in Construction

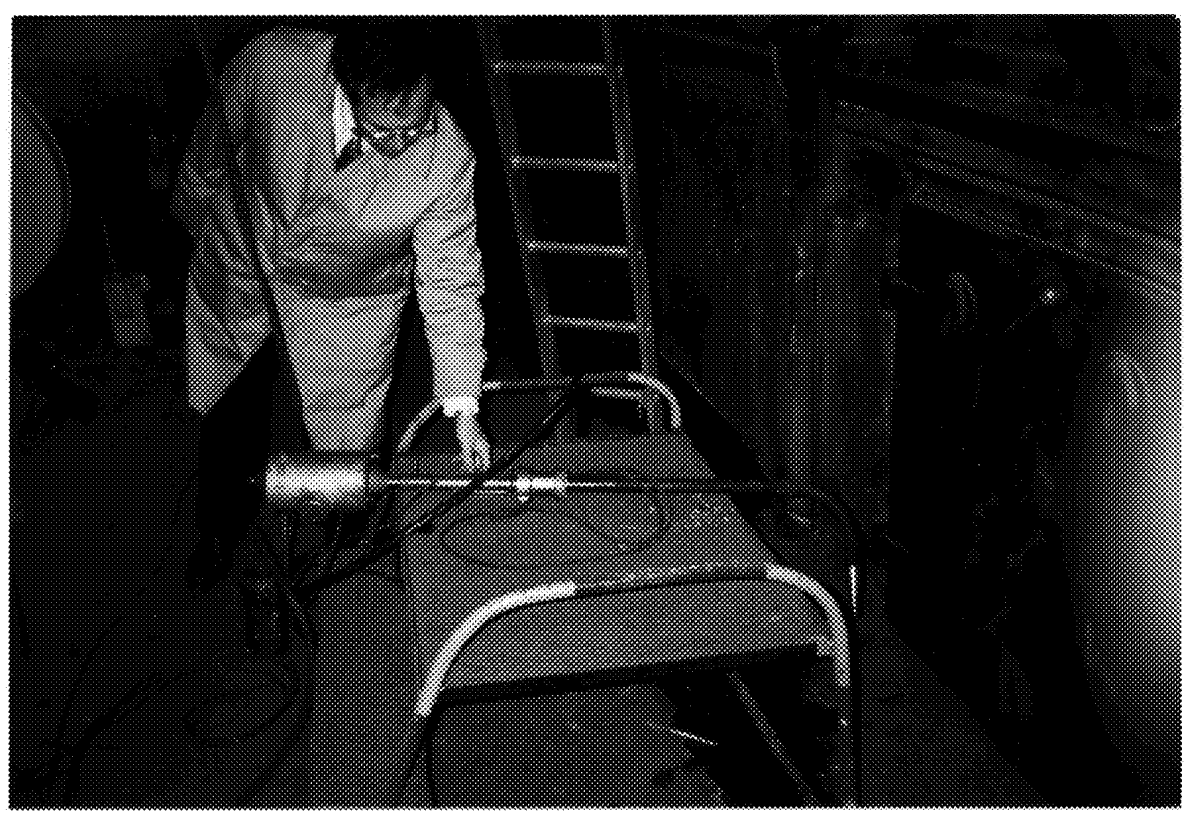

Figure 8. MPK Emission Test Equipment 


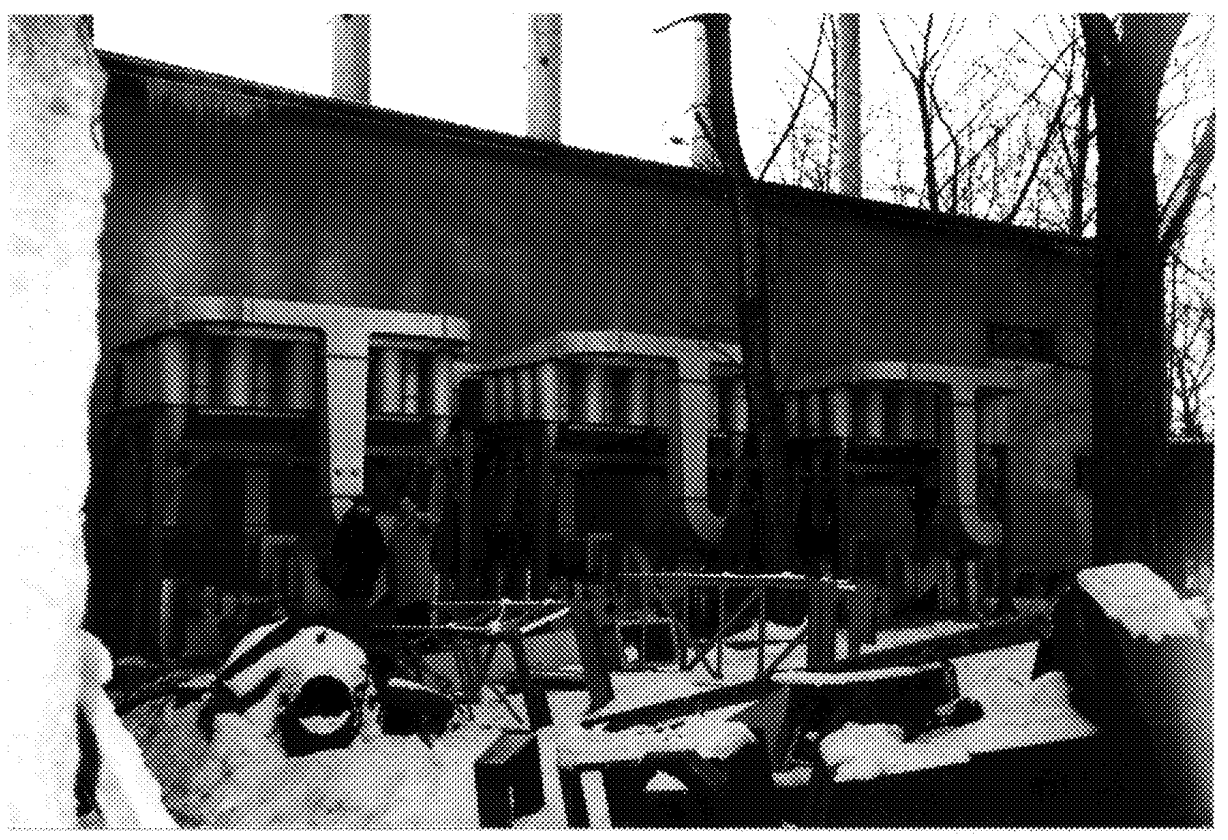

Figure 9. MPK Installation During Commissioning

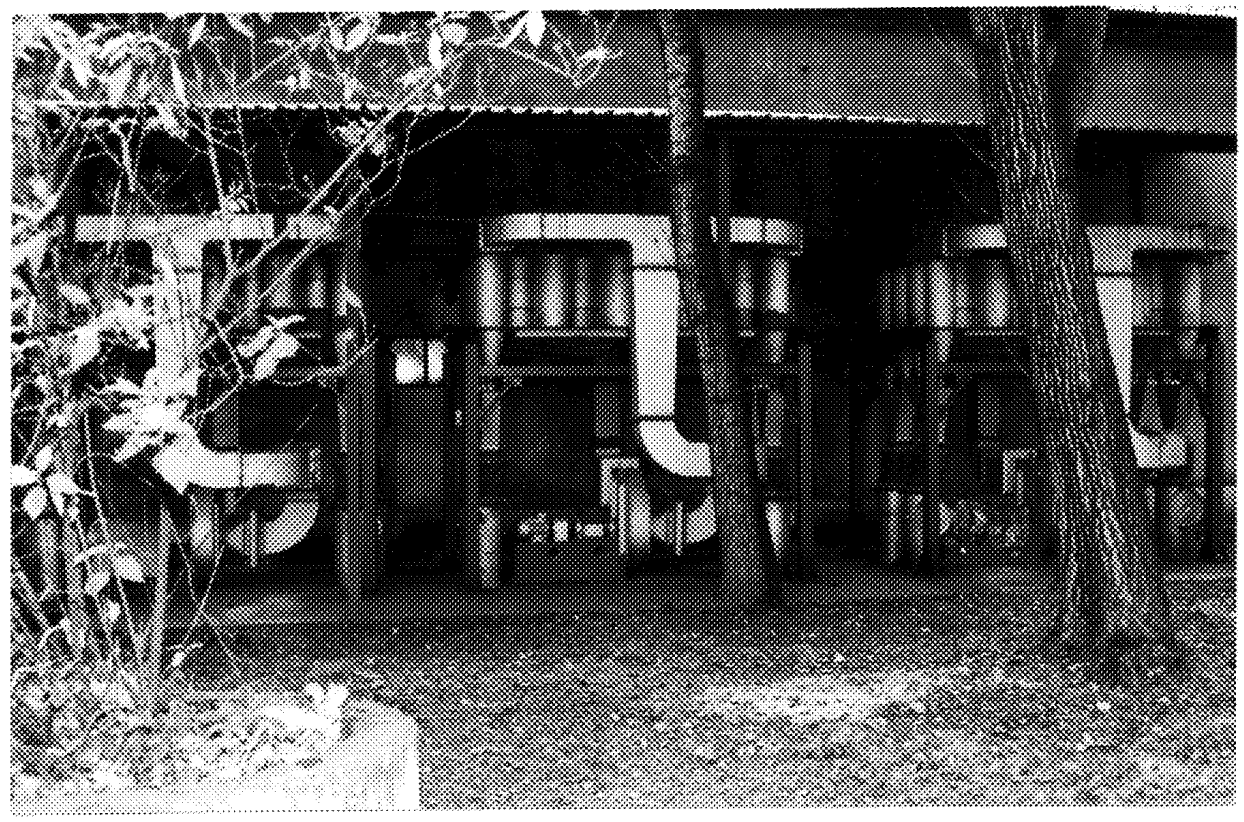

Figure 10. Completed MPK Installation 
Another Core Separator unit was installed in Krakow for the company Budostal, a producer of asphalt materials. The Budostal dust collector, shown in Figures $11 \& 12$ were designed to handle much higher dust concentrations than those found in coal-fueled heating boilers. The unit shown in Figures $11 \& 12$ was tested by Emitor and was found to have an efficiency of $98.6 \%$, making it one of the most efficient units built by EcoInstal.

\subsection{Other Core Separator Units Installed in Poland}

The first Core Separator installation that was undertaken by EcoInstal in Poland was contracted to a boilerhouse in the village of Oborniki, which is located just north of Poznan. The site was a typical boilerhouse rehabilitation where an old worn-out multicyclone was replaced and upgraded. The multicyclone had been collecting dust emissions from a WR 2.5 stoker-fired boiler. Figures $13 \& 14$ show the arrangement of the installation at Oborniki.

Dust emissions from the Core Separator unit at Oborniki were measured in early 1995 and were found to be about 10 grams/GJ. This emission level was actually quite a bit lower than expected, and the lowest measured to date. This unit remains one of the best performing units yet installed in Poland.

The next significant milestone involved an installation on a WR-10 boiler in Knurow. This boilerhouse was found to be in dire need of repair and reconditioning, and the stack opacity was visibly one of the worst observed in southern Poland. The multicyclones, ID fan, and draft system from the boiler outlet to the stack were completely replaced with new equipment including a new Core Separator dust collector. The improvement in dust emissions from this boiler was drastic. The measured efficiency of the Core Separator was just over 95\%, which produced a "clear stack", even during sootblowing and part load operation.

The installation at Knurow was also tested in 1996 with sorbent injection into the boiler backpass for multipollutant control. This testing was a collaborative effort with the NALCO 
DE-FC22-94PC94111

FUELTECH company, a U.S. firm whose $\mathrm{SO}_{2} / \mathrm{NOx}$ technology is being marketed in Poland. During these tests, the dust collecting system was subjected to much higher particulate loadings from the addition of sorbents. This test was significant in that it demonstrated the compatibility of the Core Separator with other emission control technologies in the event that more stringent regulations may be mandated in the future. Photographs of the Knurow dust collection equipment is shown in Figures $15 \& 16$.

Another technical and marketing achievement completed by EcoInstal in late 1996 was the Core Separator installation for the FIAT automobile company in Bielsko-Biala. This was a significant milestone since it occurred on a WR-25 heating boiler with a gas flow rate of 140,000 $\mathrm{M}^{3} / \mathrm{h}(85,000 \mathrm{acfm})$. This facility is located about 50 kilometers southwest of Krakow, and due to prevailing winds and climatic conditions, it is an emission source which affects the city of Krakow. The Core Separator dust collector at FIAT AUTOPOLAND went into operation in 1997 and has met performance expectations. Photographs of the FIAT installation are shown in Figures 17-20.

As of the writing of this report, about forty-five (45) Core Separator installations have been completed in Poland. Table 1 provides a list of all installations completed to date. As shown in this table, these installations represent about 250 MWe of equivalent boiler capacity. 
DE-FC22-94PC94111

Table 1. Core Separators Produced by EcoInstal

\begin{tabular}{|c|c|c|c|c|c|}
\hline & Installation & $\begin{array}{l}\text { No. of } \\
\text { Units }\end{array}$ & $\begin{array}{l}\text { Initial } \\
\text { Operation }\end{array}$ & Capacity $(\mathbf{m} 3 / \mathbf{h})$ & $\underline{\text { Application }}$ \\
\hline 1. & PEC Oborniki & 1 & $4 / 95$ & 10,000 & WR-2.5 Stoker Boiler \\
\hline 2. & EXBUD Tarnow & 2 & $5 / 95,6 / 96$ & 7,300 & Fluidized Bed Boilers \\
\hline 3. & Kombinat RSP Czempin & 3 & $8 / 95$ & 18,000 & WCO-80 Stoker Boilers \\
\hline 4. & PEC Knurow & 1 & $10 / 95$ & 50,000 & WR-10 Stoker Boiler \\
\hline 5. & MPK Krakow & 3 & $1 / 96$ & 5,600 & WCO-80 Stoker Boiler \\
\hline 6. & Armatura Krakow & 1 & $1 / 96$ & 22,600 & WR-5 Stoker Boiler \\
\hline 7. & Institute Non Ferrous Metals & 1 & $6 / 96$ & 2,000 & Copper Smelter \\
\hline 8. & Matizol Gorlice & 2 & $3 / 96$ & 10,000 & Asphalt Plant Drier \\
\hline 9. & Odlewnia Zeliwa & 1 & $3 / 96$ & 25,000 & OKR-5 Stoker Boiler \\
\hline 10. & Argentchem Opalenica & 1 & $6 / 96$ & 800 & Smelting Furnace \\
\hline 11. & Klimawentex Rzeszow & 3 & $6 / 96$ & 3,000 & Glassmelting/Sanderdust \\
\hline 12. & Budostal Krakow & 1 & $6 / 96$ & 21,600 & Rotary Drier/Asphalt \\
\hline 13. & Zaklad Farbiarski Warsaw & 1 & $6 / 96$ & 9,000 & PCO-60 Heating Boilers \\
\hline 14. & FIAT Auto Poland & 1 & $1 / 97$ & 140,000 & WR-25 Stoker Boiler \\
\hline 15. & Krakodlew-Krakow & 1 & $2 / 97$ & 8,000 & Rotary Drier/Sand \\
\hline 16. & Cementownia Strzelce & 1 & $2 / 97$ & 6,400 & Cement Kiln Drier \\
\hline 17. & Zembiec Zembcu & 1 & $3 / 97$ & 35,000 & Rotary Drier/Bentonite \\
\hline 18. & PDM-Koscian & 1 & $4 / 97$ & 21,600 & Asphalt Dryer \\
\hline 19. & EkoBud-Grudziadz & 1 & $4 / 97$ & 3,500 & SR-15 Boiler \\
\hline 20. & ExBud-Tarnow & 1 & $4 / 97$ & 5,800 & Fluidized Bed Boiler \\
\hline 21. & Skleja Eko-Ostrow & 1 & $7 / 97$ & 13,600 & WLM-2.5 Boiler \\
\hline 22. & Czech Technical University & 1 & $10 / 95$ & 2,500 & Fluidized Bed Boiler \\
\hline 23. & Firma Dragowa Kutnie & 1 & $3 / 97$ & 45,000 & Rotary Drier/Asphalt \\
\hline 24. & PZL-Wola Warsaw & 2 & $3 / 97$ & 100,400 & WR-5 Boilers \\
\hline 25. & Sp. Energ. S.A. Moszczenica & 1 & $10 / 97$ & 120,000 & PWRp 20 Boiler \\
\hline 26. & Ferney Spinning Mills, Mauritius & is 1 & $12 / 95$ & 30,000 & Stoker Boiler \\
\hline 27. & ZRD Poznan & 1 & $3 / 98$ & 100,000 & Rotary Dryer/Asphalt \\
\hline 28. & MZC Dzierzoniow & 3 & $4 / 98$ & 108,000 & WR-5 Boilers \\
\hline 29. & S.P. Energ. S.A. Pniowek & 1 & $6 / 98$ & 110,000 & WR-25 Boiler \\
\hline 30. & Zak. Energ. Cieplnej. Katowice & 1 & $7 / 98$ & 120,000 & WR-25 Boiler \\
\hline 31. & Daewoo Lublin & 2 & $9 / 98$ & 220,000 & EKM-50 Boiler \\
\hline 32. & Huta Im. Cedlera Sosnowiec & 2 & $9 / 98$ & 180,000 & OR-32 Boilers \\
\hline \multirow[t]{2}{*}{33.} & Cukrownia Raciborz & $\underline{2}$ & $10 / 98$ & $\underline{210,000}$ & OR-32 Boilers \\
\hline & & 47 & & $1,764,700$ & \\
\hline
\end{tabular}


DE-FC22-94PC94111

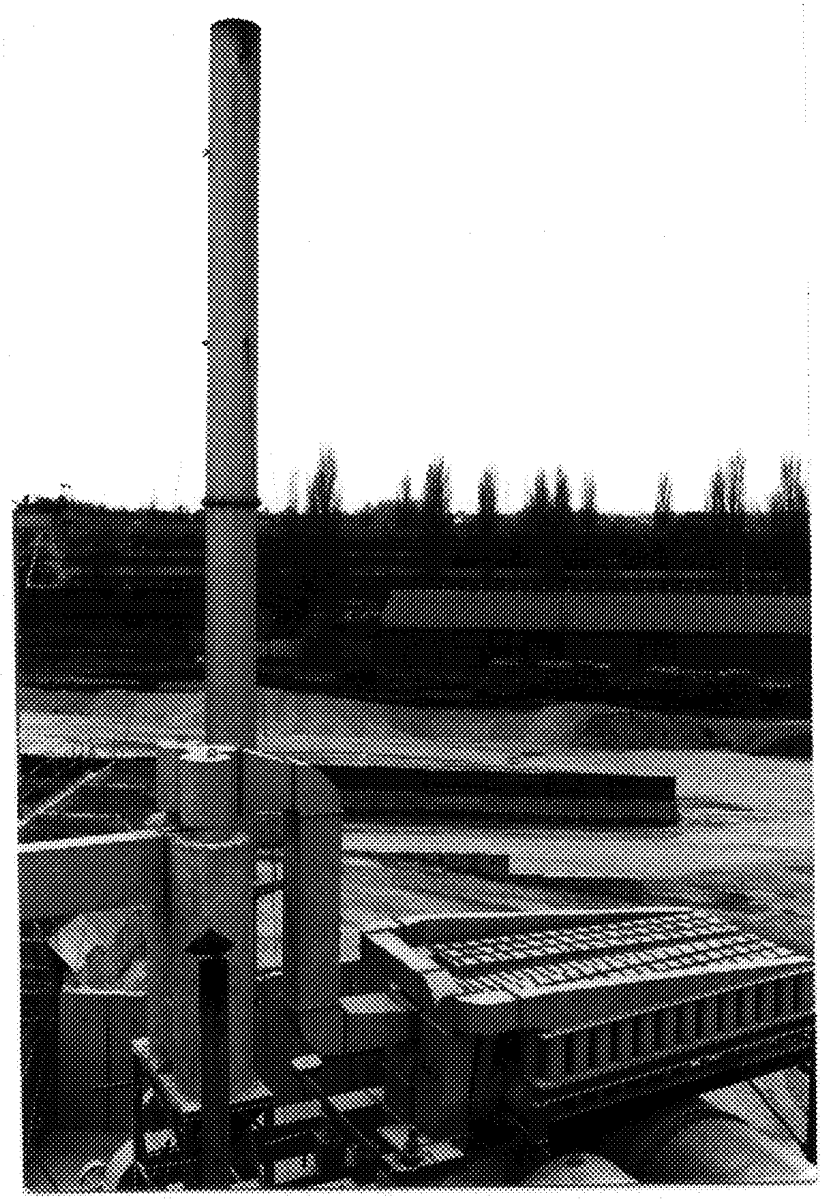

DE-FC22-94PC94111

Figure 11. Budostal

Krakow Core Separator

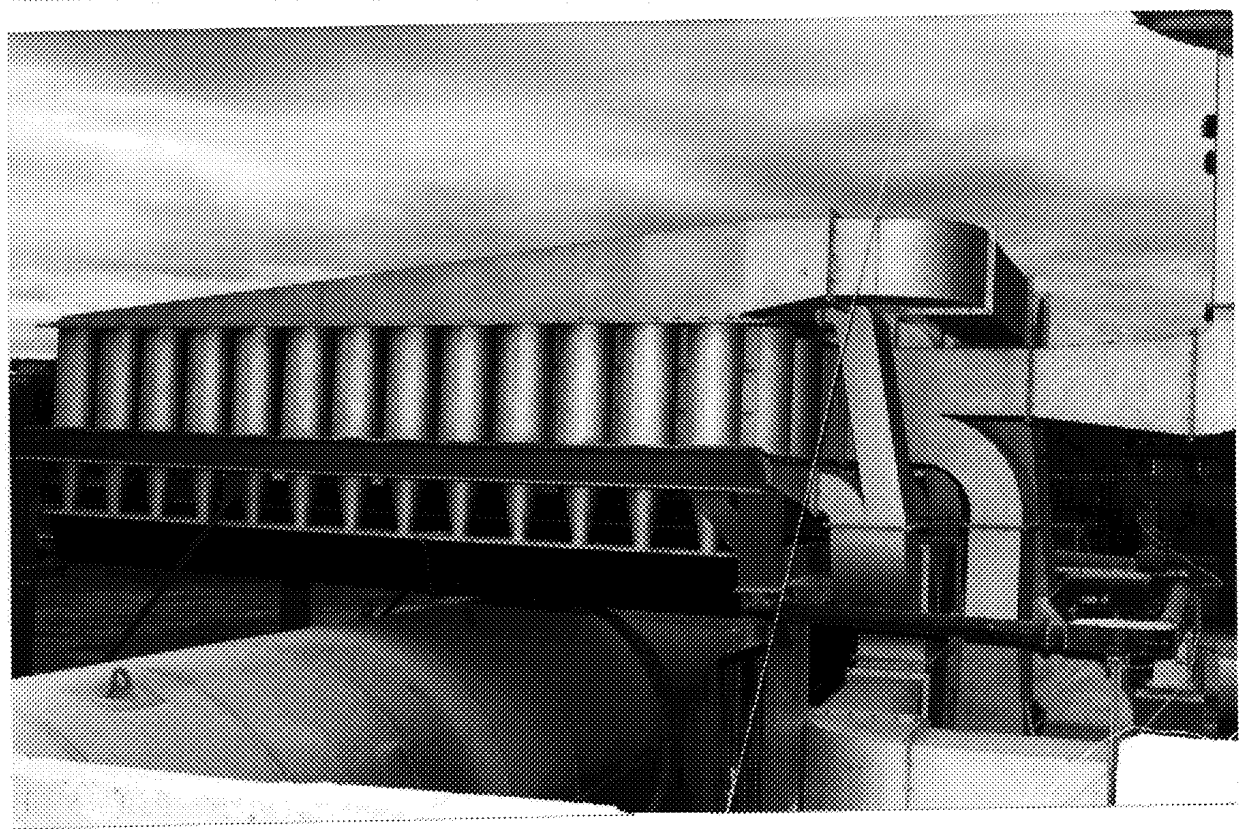




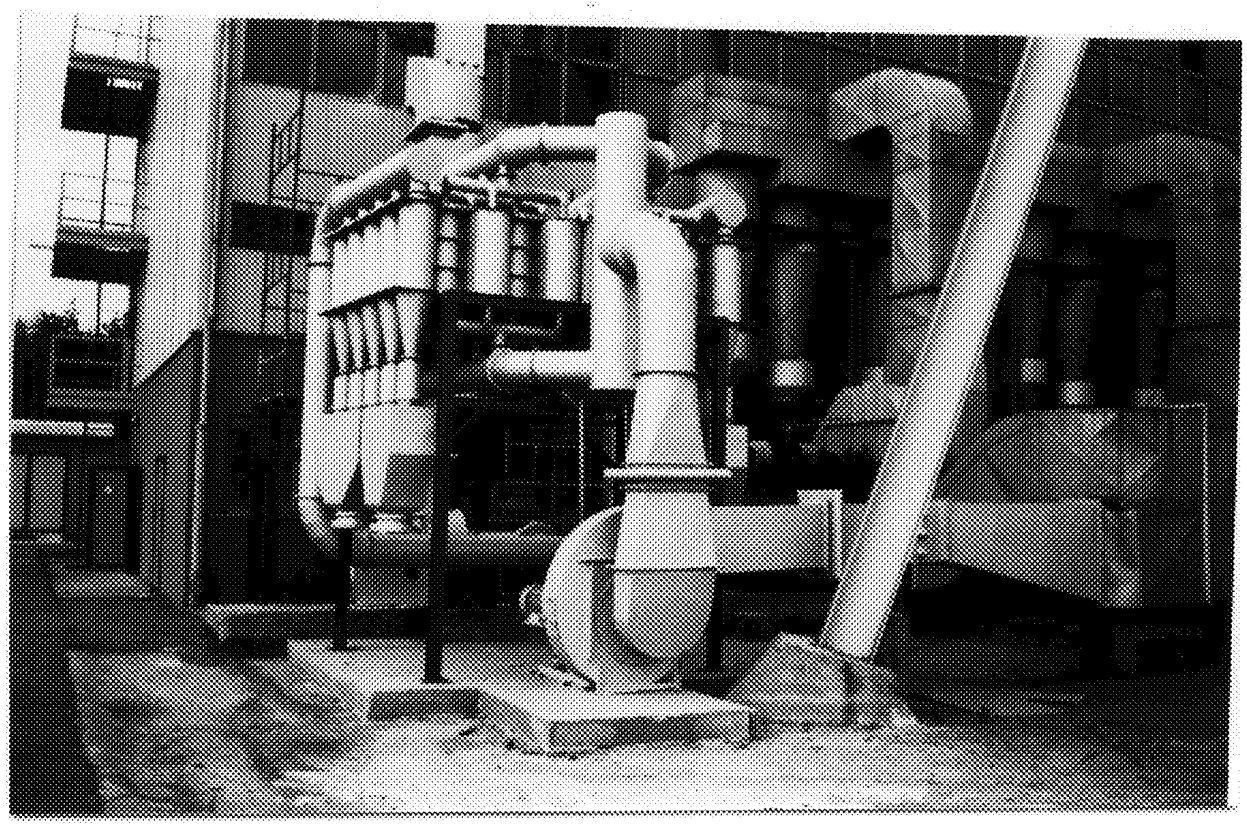

Figure 13. Core Separator Installation - Oborniki

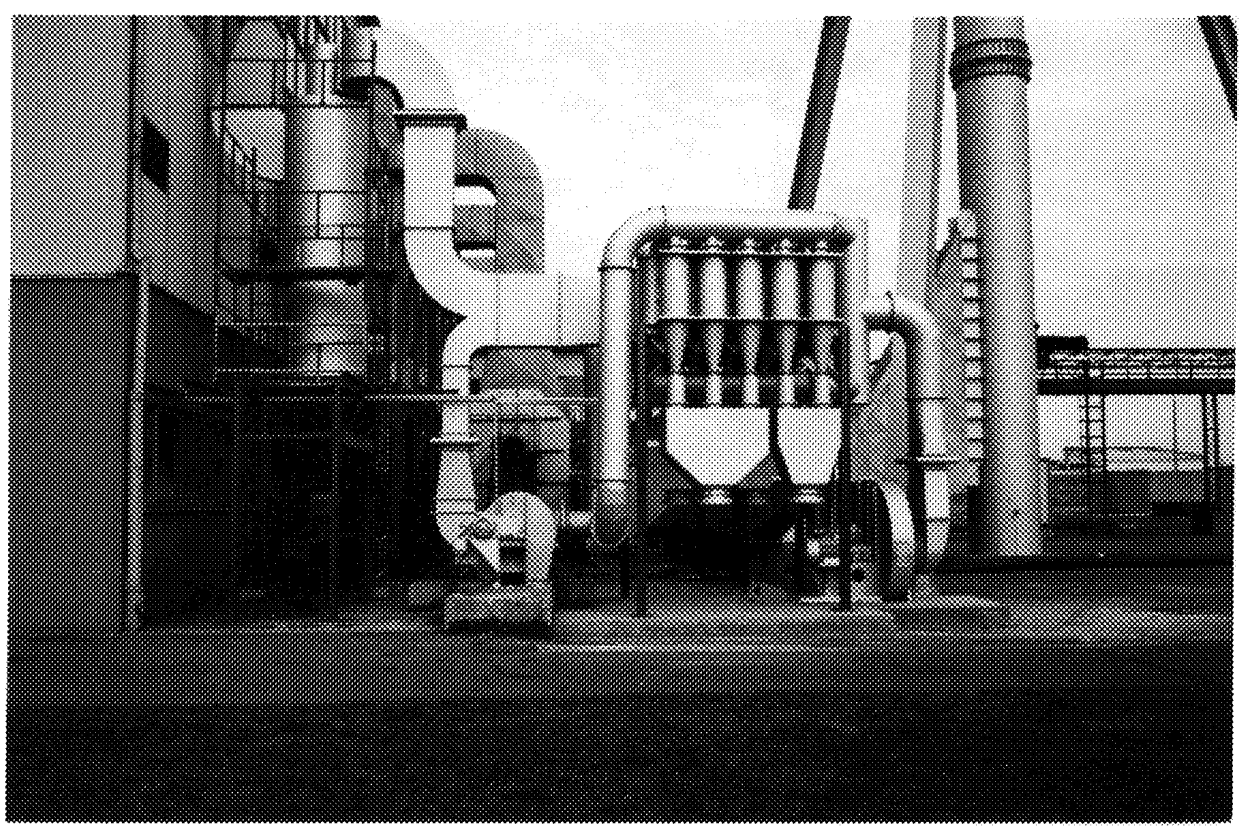

Figure 14. Side View - Obonniki Core Separator 


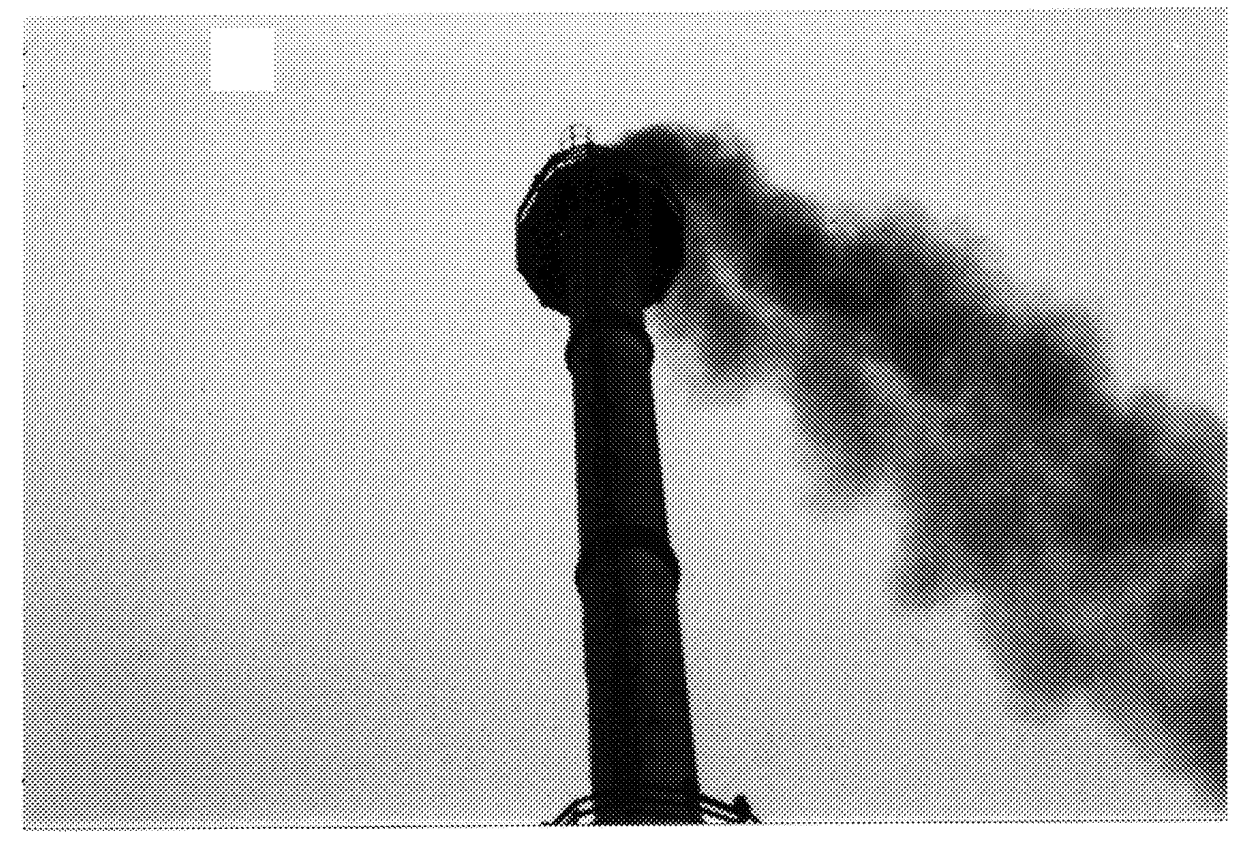

Figure 15. Stack Condition at Knurow Prior to Core Separator

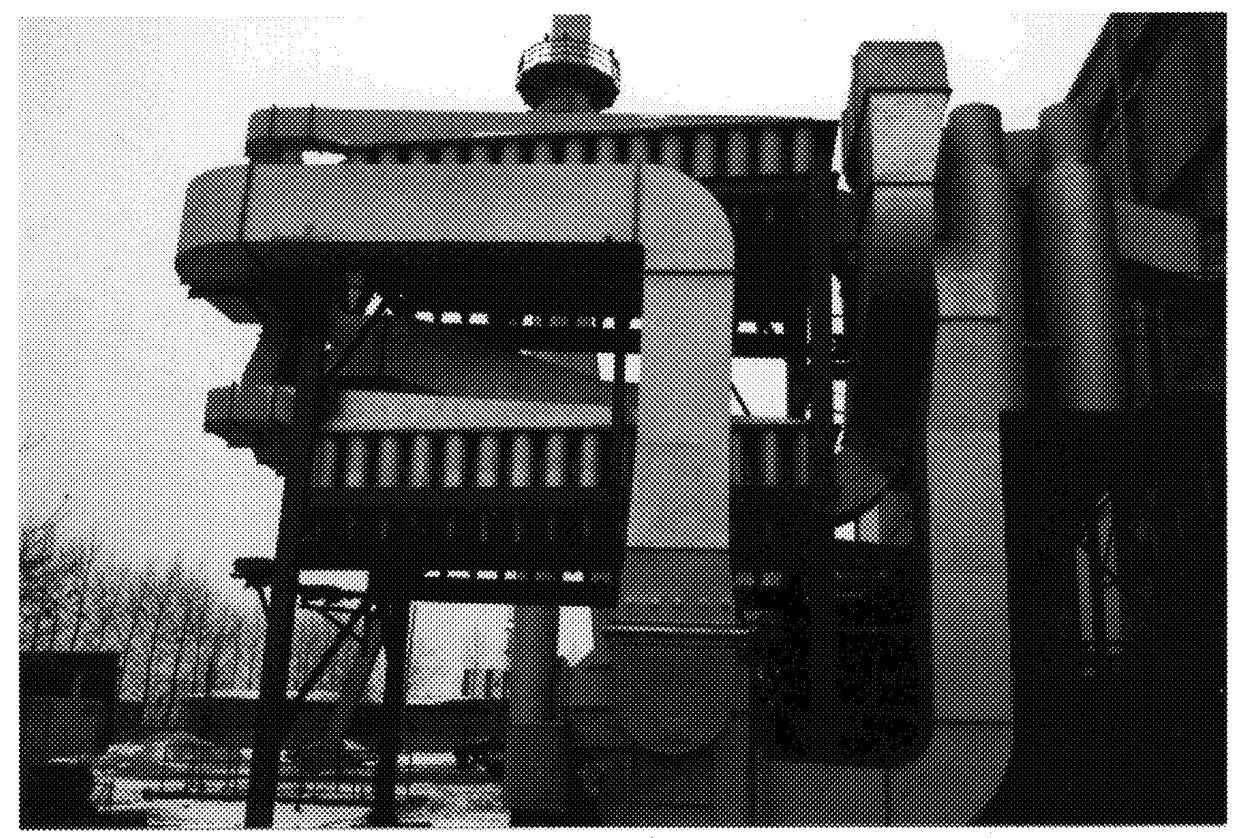

Figure 16. Core Separator Installation * Knurow 


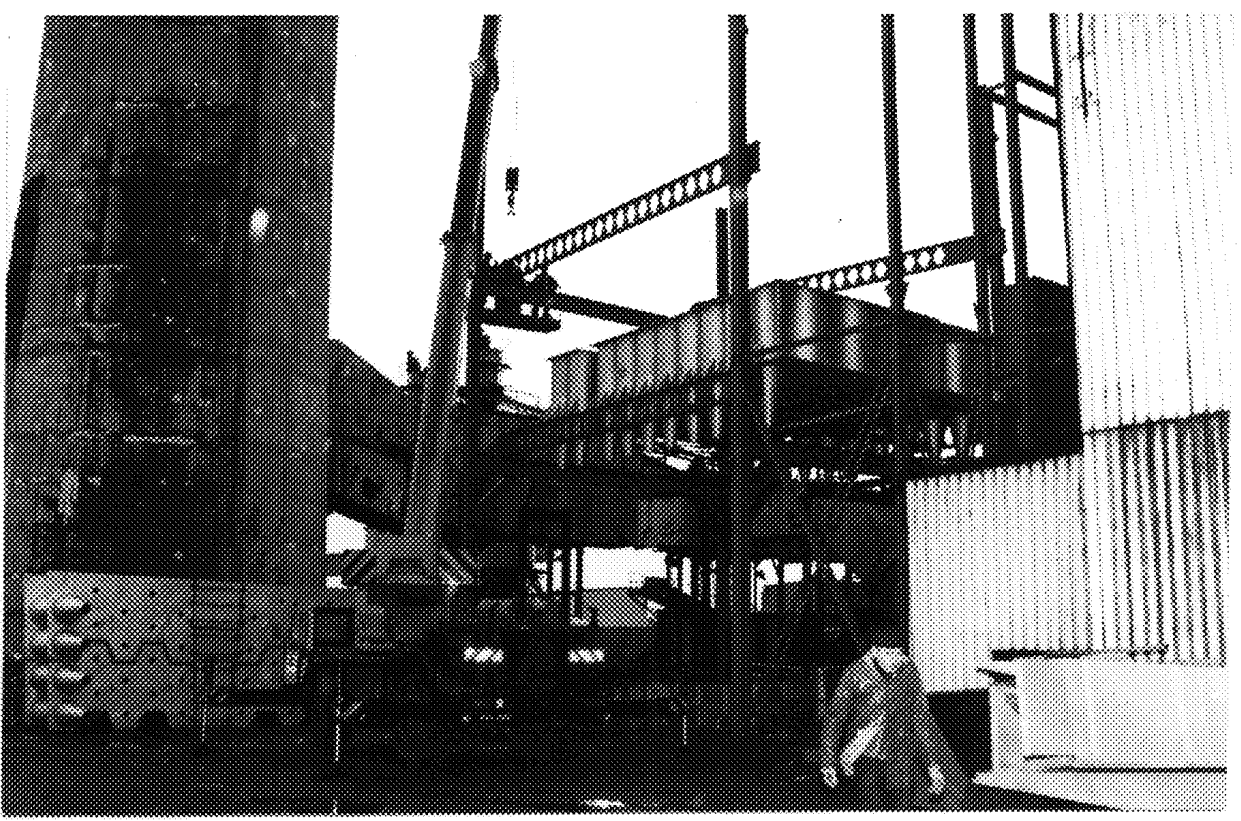

Figure 1\%. Structural Steel Installation - FIAT AUTOPOLAND

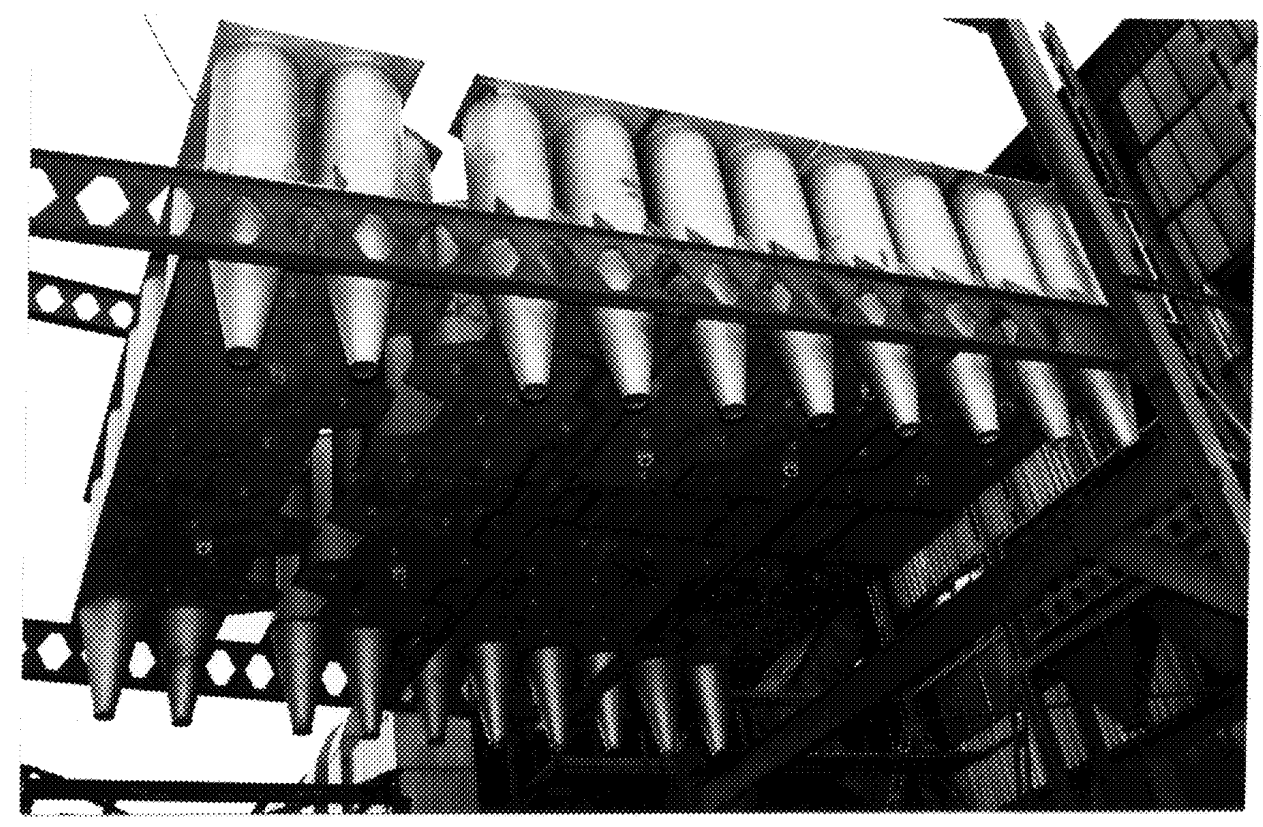

Figure 18. Core Separator Module Instatlation - FIT AUTOPOLAND 


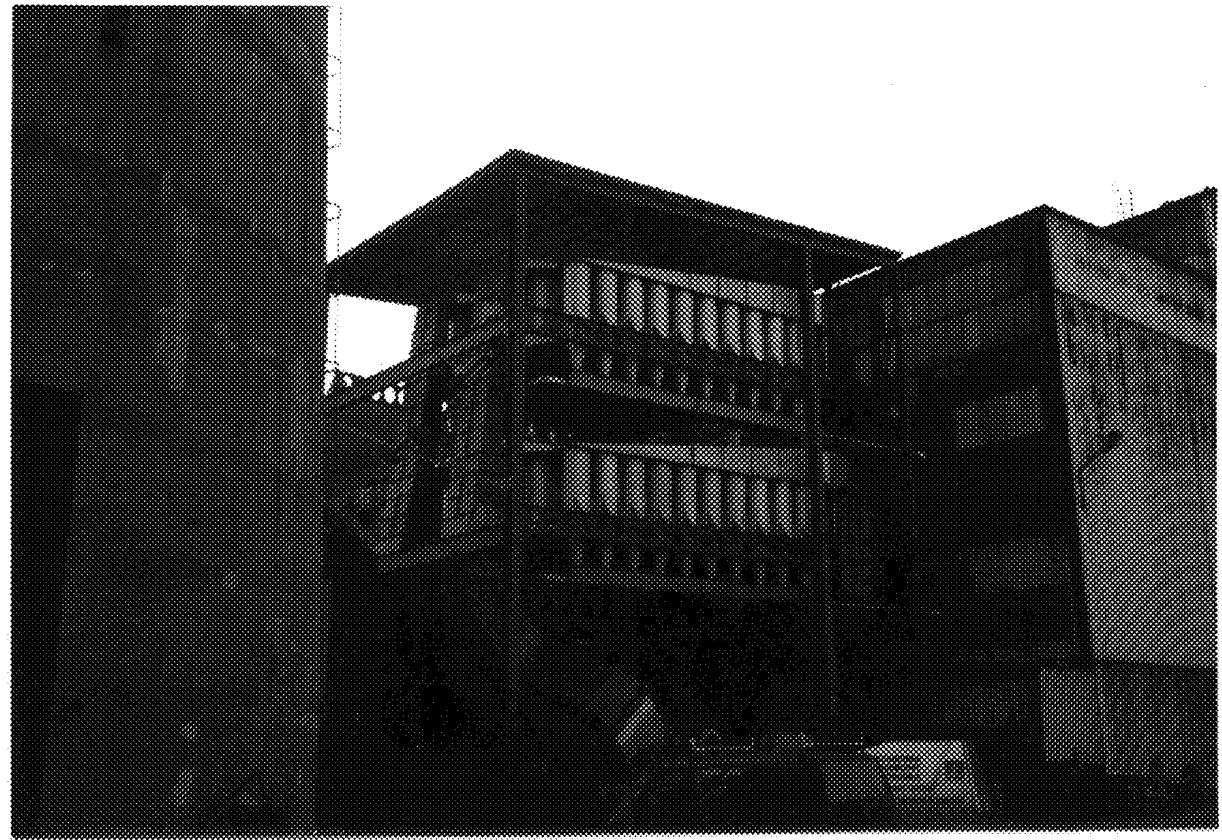

Figure 19. Core Separator Near Complete - FIAT AUTOPOLAND

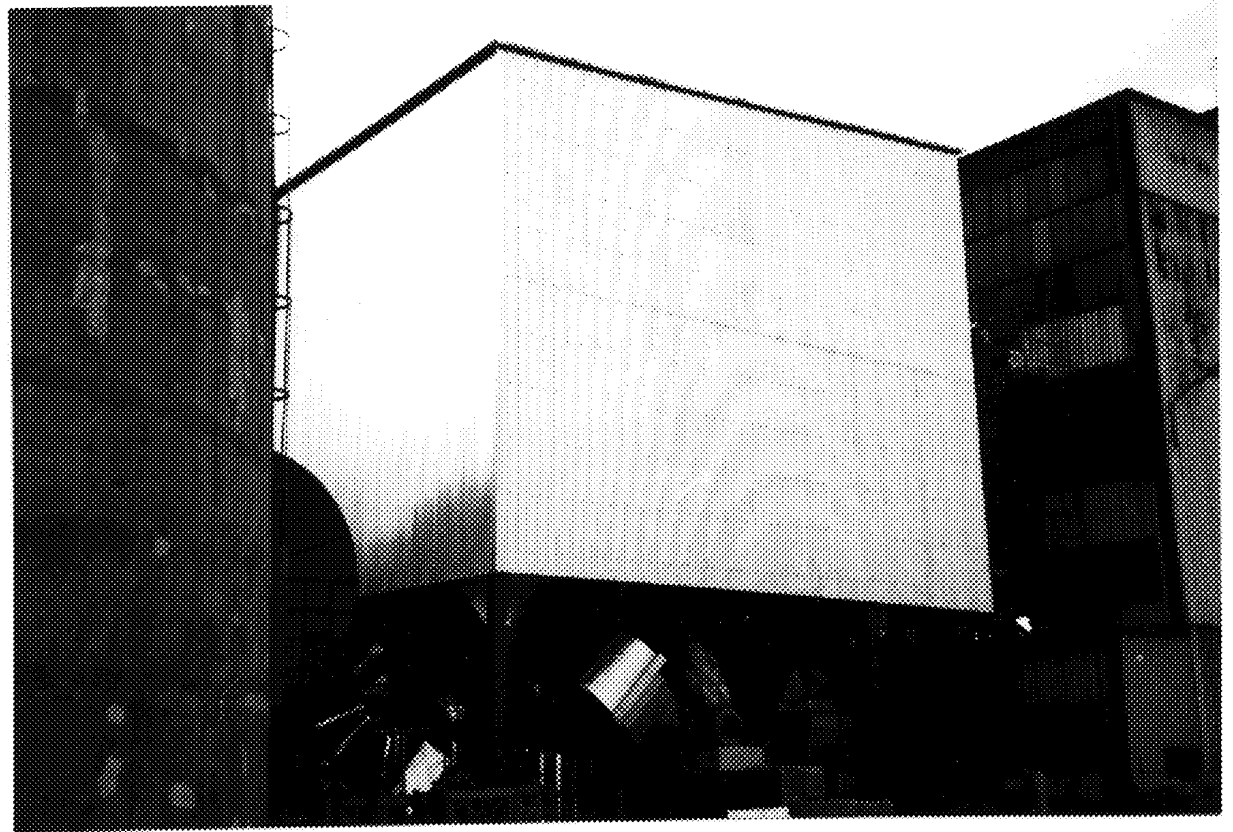

Figure 20. Completed Core Separator - FIAT AUTOPOLAND 
DE-FC22-94PC94111

\subsection{Effect on Emission Reductions}

The implementation of Core Separator dust collectors throughout Poland has had a significant impact on emissions reduction. An example of this can be seen in the Case Study shown below for a WR-10 boiler. This comparison shows that when a Core Separator is installed as a replacement for multicyclones, the average emission rate is reduced from about $300 \mathrm{mg} / \mathrm{NM}^{3}$ to $80 \mathrm{mg} / \mathrm{NM}^{3}$. Thus, based on typical boiler operating factors, the reduction in dust emissions annually with a replacement Core Separator is approximately 28.9 metric tons for a typical WR-10 boiler.

\section{Case Study}

WR 10-011 Boiler

- Coal Consumption

- Flue Gas Temp.

$2,560 \mathrm{~kg} / \mathrm{h}$

- Boiler Efficiency

200 deg. C

80 Pct.

- Operating Factor 240 days/yr.

Dust Emissions with Cyclone Collector

- Average Emission

$300 \mathrm{mg} / \mathrm{M}^{3}$

- Annual Emission

$39,485 \mathrm{~kg}$

Dust Emissions with Core Separator

- Average Emission

- Annual Emission

$80 \mathrm{mg} / \mathrm{M}^{3}$

$10,529 \mathrm{~kg}$

Difference in Dust Emission

$28.9 \mathrm{MT} / \mathrm{yr}$.

By using similar assumptions, a more comprehensive analysis can be applied to the entire list of Core Separators produced by EcoInstal (Table 1) to obtain an estimate of emissions reduction from all sources. Below, this estimate has been made for the five (5) operational Core Separators in Krakow and for the forty-five (45) units located throughout Poland.

Estimate of Particulate Emission Reduction Attributed to Core Separator Installations

Location (\# Units)

Krakow Region (5)

All of Poland (45) $\underline{\text { Particulate Emissions Reduced, Metric Tons/Year }}$

116.6

$2,154.0$ 
DE-FC22-94PC94111

\subsection{Core Separator Marketing Efforts in Poland}

Since 1995, EcoInstal and LSR expended considerable effort in marketing new technology throughout a region that is badly in need of emission control technology. The marketing efforts consisted of the following endeavors:

- $\quad$ Prepared and published technical papers in Polish trade journals

- Attended and exhibited at numerous trade shows

- Made presentations to industry executives and local government officials

- Advertised in select environmental trade magazines

Although EcoInstal exhibited at many trade shows in and near Krakow, it also exhibited at the large international fair known as EcoPol held annually in Poznan. EcoPol is a major world-class environmental trade fair with more than 1,000 exhibiting companies from 190 different countries. Several trade shows were also attended in various cities in Silesia, and in Plzen and Brno of the Czech Republic. Figures 21-24 contain photographs of Core Separator materials that were exhibited at EcoPol.

\subsection{Awards and Citations}

EcoInstal received two prestigious awards in 1996 and 1997 which were directly related to accomplishments associated with this project and the Core Separator. These awards are:

(1) 1996 Best Exhibitor Award at EcoPol Trade Show: This award was made to only five (5) companies in a highly competitive selection process that included more than 2,000 eligible firms.

(2) 1997 Polish Environmental Leadership Award: This award, given annually by the Minister of the Environment in Poland, was made to EcoInstal and four (4) other 
DE-FC22-94PC94111

companies for exceptional contributions to environmental cleanup. Most of these contributions were related to Core Separator installations.

\subsection{Modernization of Manufacturing}

In 1996, EcoInstal made a substantial investment to enlarge and improve its production capability. This investment was justified largely by the increase in sales activity from Core Separator installations. Having outgrown its $1,000 \mathrm{~m}^{2}$ facility, the company acquired and moved into a renovated 5,000 $\mathrm{m}^{2}$ facility, and obtained additional equipment for metal-working, welding, and processing large fabricated components.

The process of upgrading the manufacturing process actually involved a major collaborative effort between LSR and EcoInstal. This effort included the following:

(a) Developing Modular Designs for Small and Large Capacity Units: LSR developed detailed manufacturing drawings with AutoCad® software to produce a maximum number of common (or identical) parts in all contracted units. Although all Core Separator units are custom-designed, a modular concept is essential for scale-up in size and to insure low-cost production.

(b) Technology Transfer from Developer to Manufacturer: Production drawings developed by LSR were adapted to Polish material specifications for sheet steel sizes and thicknesses and conveyed to EcoInstal. AutoCad® drawings were prepared for CNC (computer numerical control) adaptation to the extent possible. LSR's computer performance model was also transferred for the purpose of predicting performance and developing arrangement designs.

(c) Fixtures for Producing Modules: Jigs and fixtures were constructed for all common pieces used in Core Separator modules. The fixtures are a way of standardizing the 
manufacture of as many component parts as possible.

(d) Addition of New Production Equipment: Following a visit to the U.S. and tour of several mid-sized sheet metal companies, EcoInstal acquired a new brakepress, guillotine shearer, improved welders, and other miscellaneous equipment.

(e) Technical Training of Production Workers: LSR engineers together with EcoInstal management conducted a comprehensive training program for all production workers including CAD/CAM techniques and quality control. This effort was made to implement western manufacturing standards and to prepare EcoInstal for the process of ISO-9000 requirements.

As a result of this upgrading, today EcoInstal is a reputable manufacturer that can compete with just about any sheetmetal company with respect to cost and product quality. Figures 25-30 contain photographs of several steps in the manufacturing sequence of commercial Core Separator units at EcoInstal. 


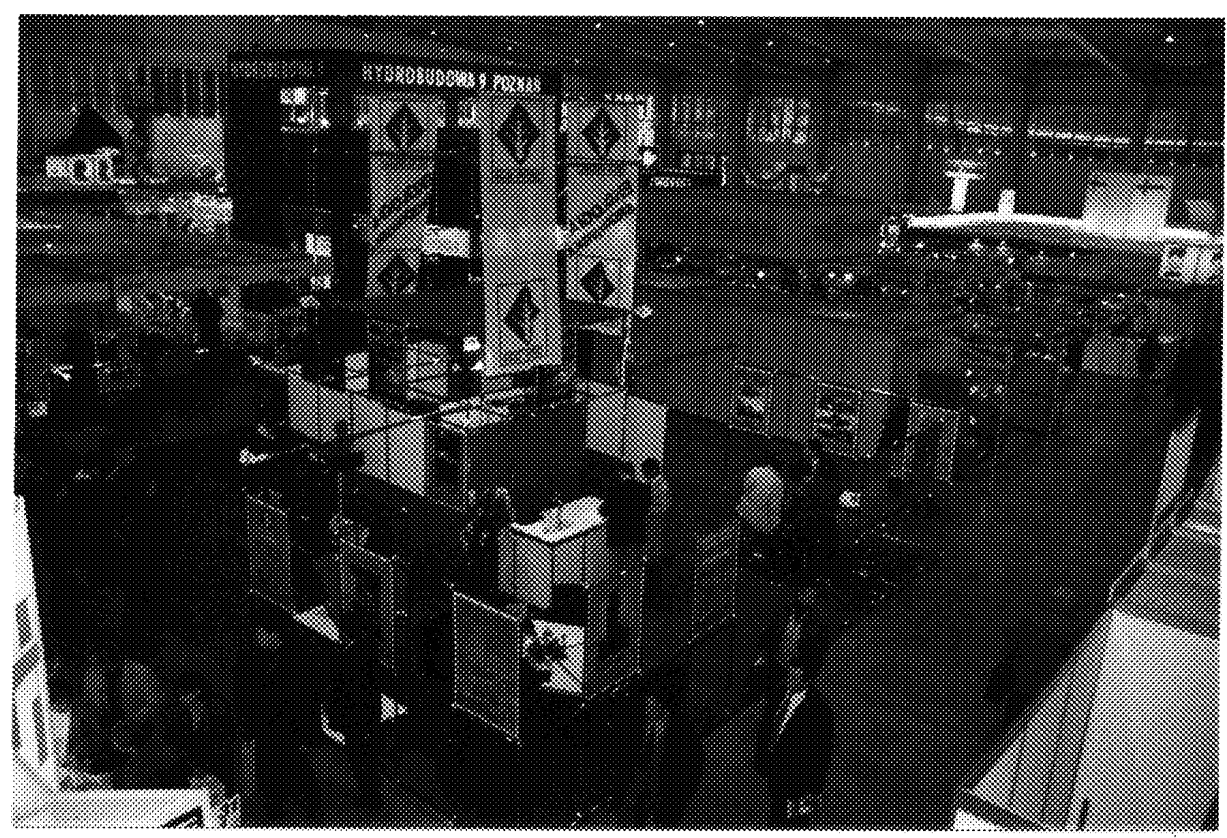

Figure 21. Ecolnstal Exhibit - EcoPol Trade Show

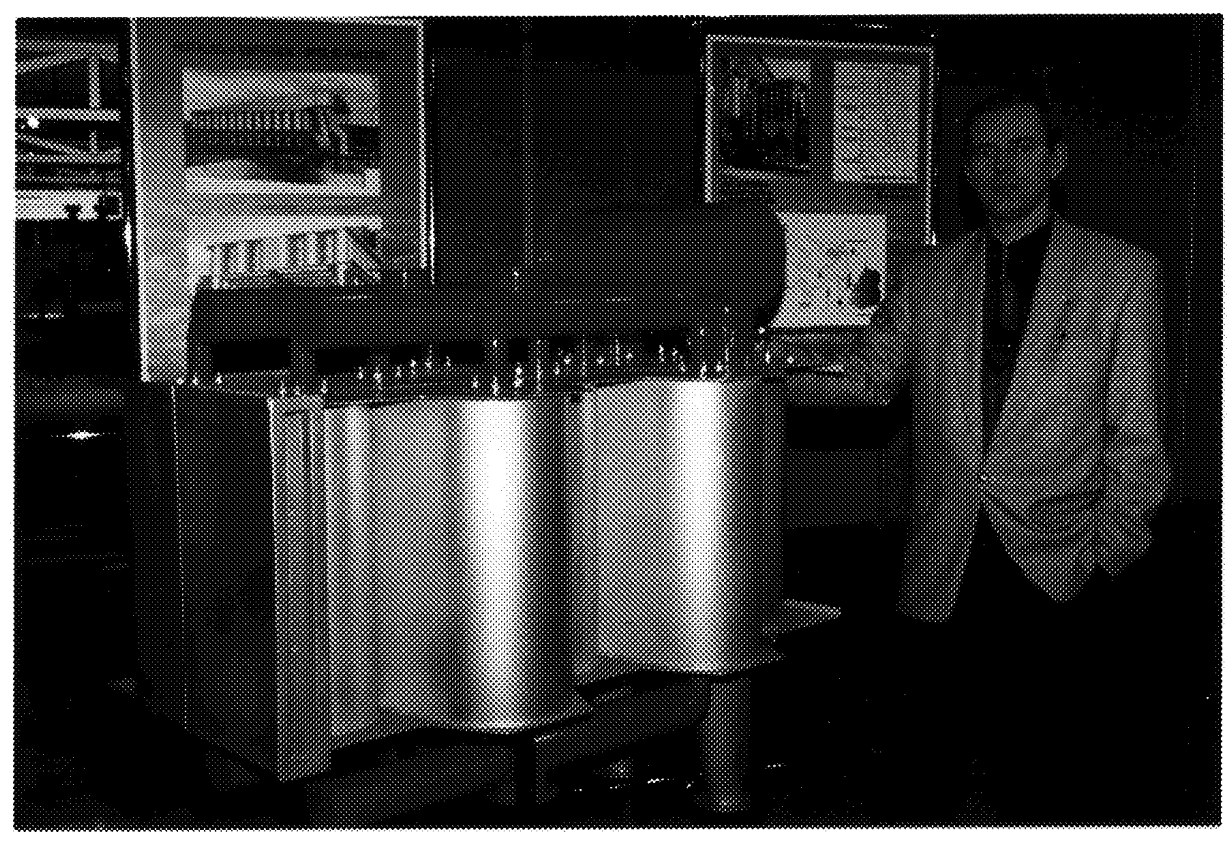

Figure 22. Core Separator Exhibit - EcoPol Trade Show 


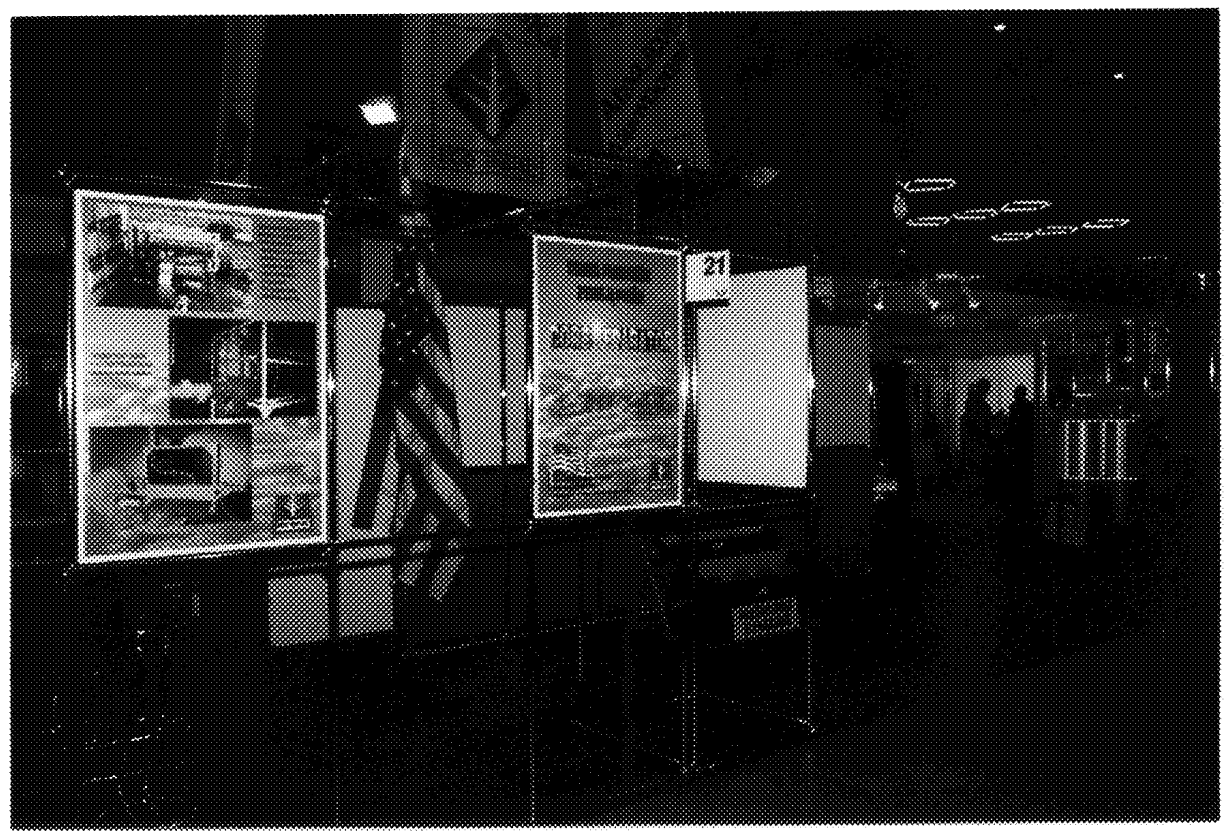

Figure 23. Polish/U.S. Exhibit - EcoPol Trade Show

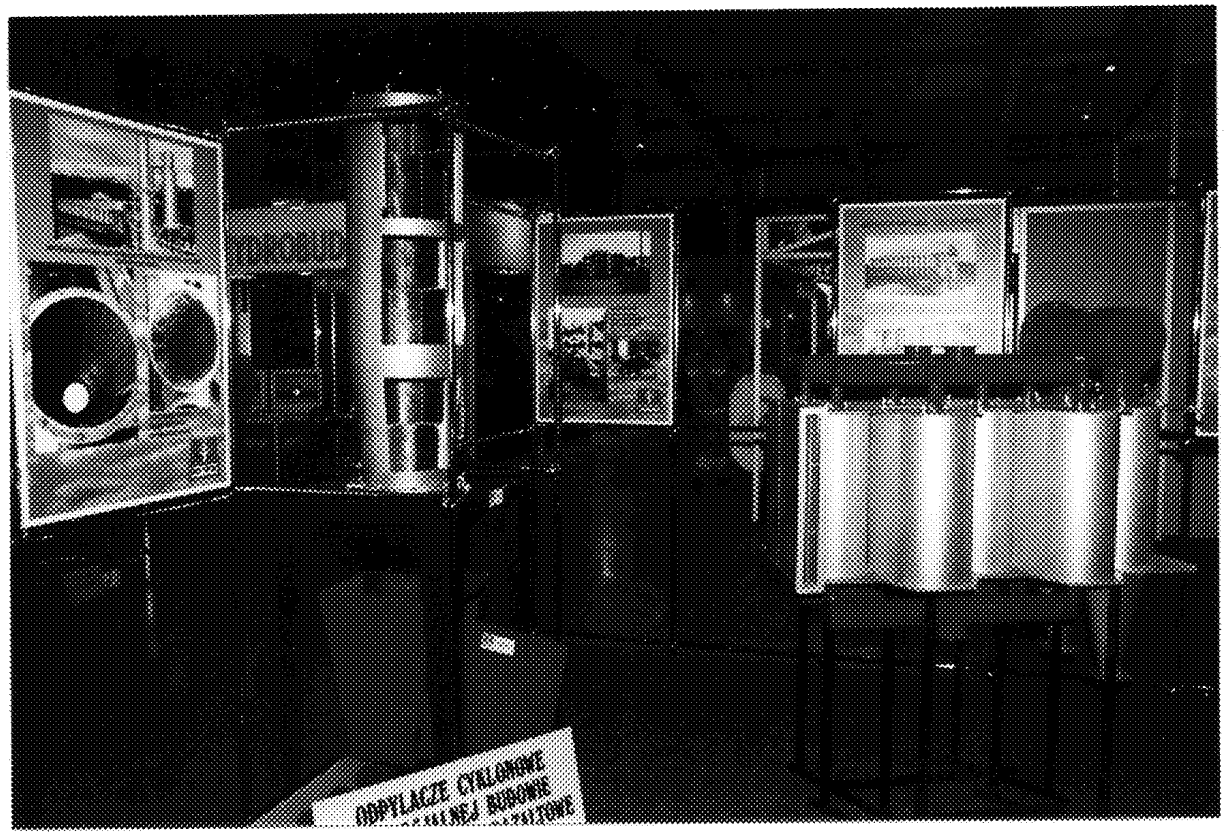

Figure 24. Equipment Display - EcoPol Trade Show 


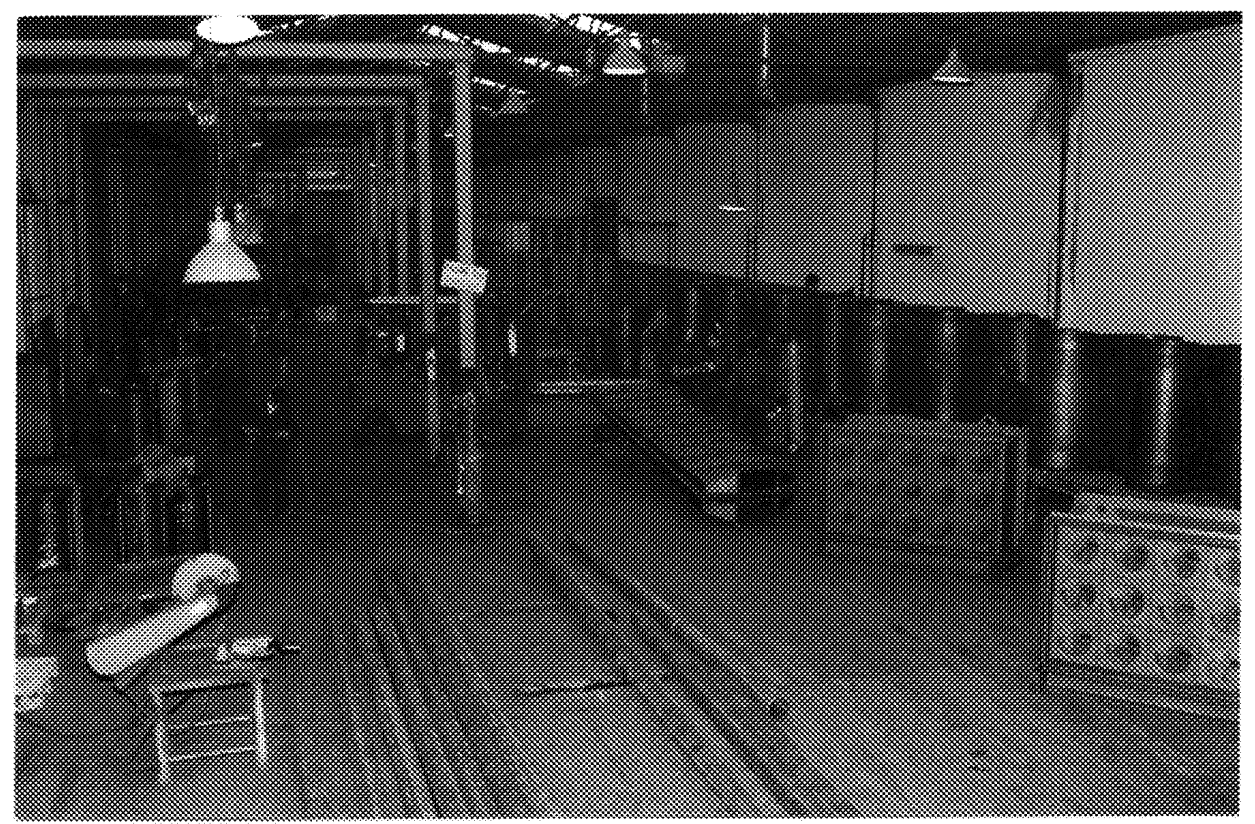

Figure 25. Core Separator Production at Ecolnstal

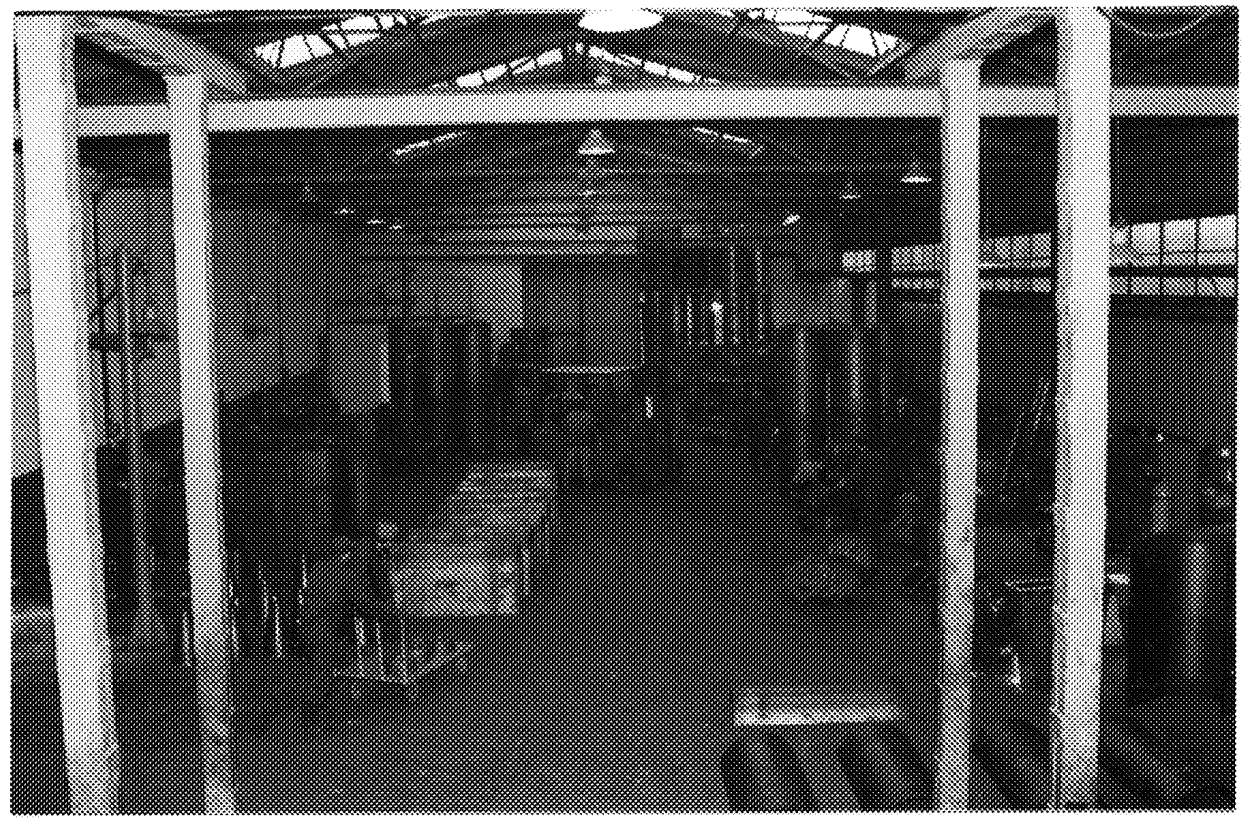

Figure 26. Production Sequence at Ecolnstal 


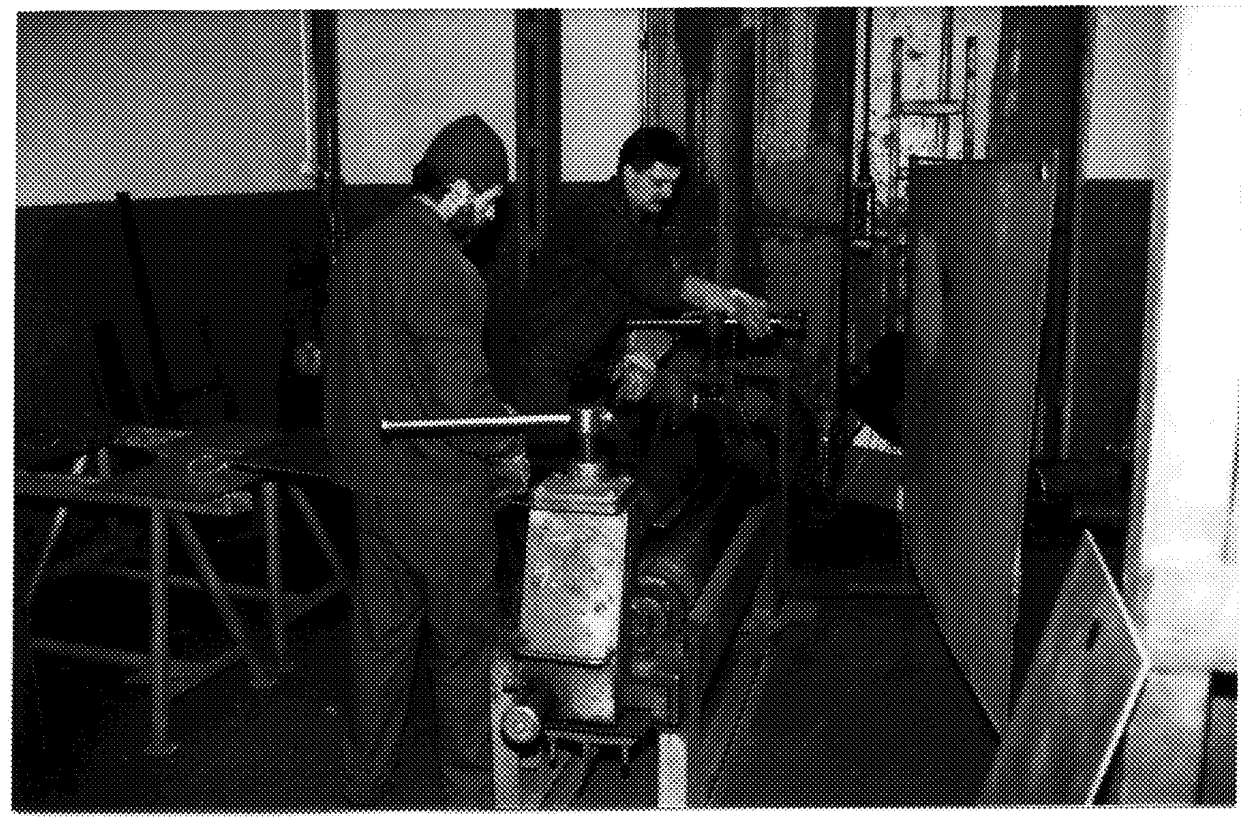

Figure 27. Initial Forming of Core Separator Module



Figure 28. Quality Control Department - Ecolnstal 


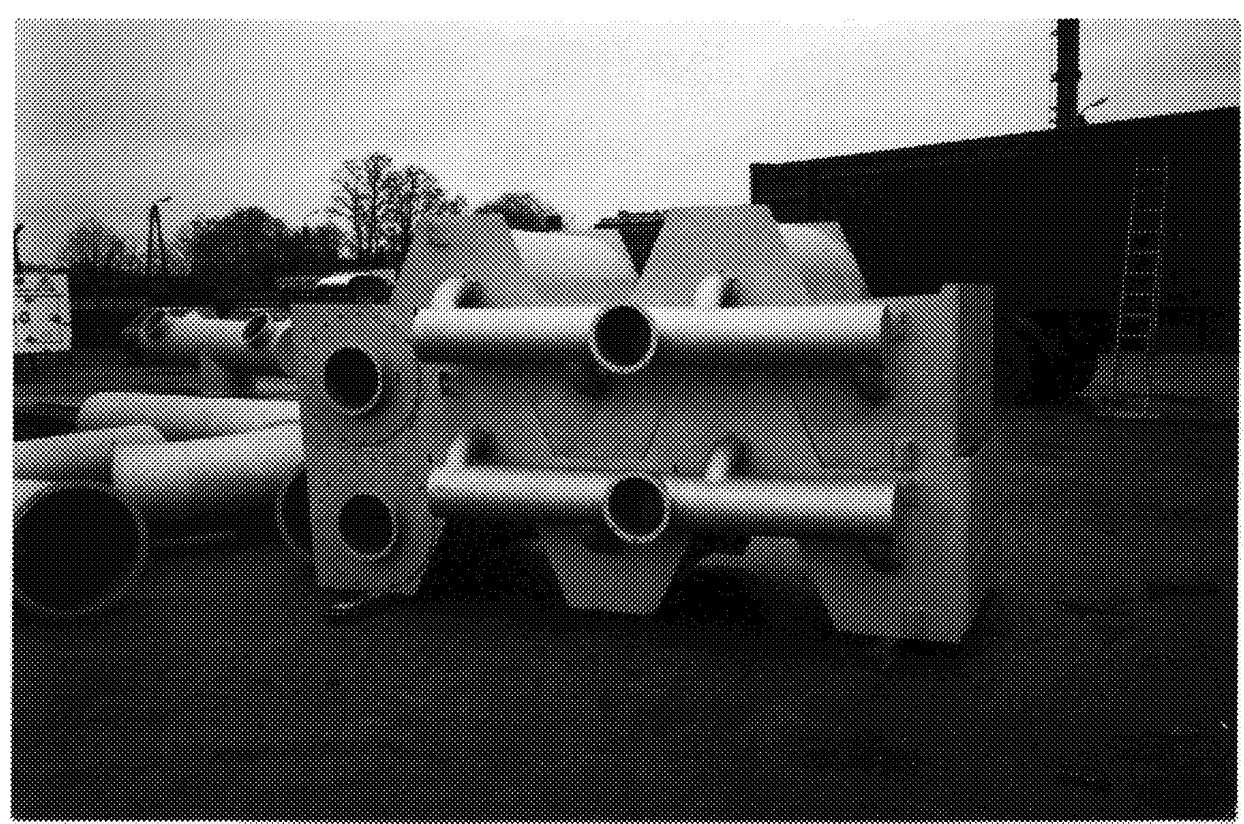

Figure 29. Completed Core Separator Modules - Ecolnstal

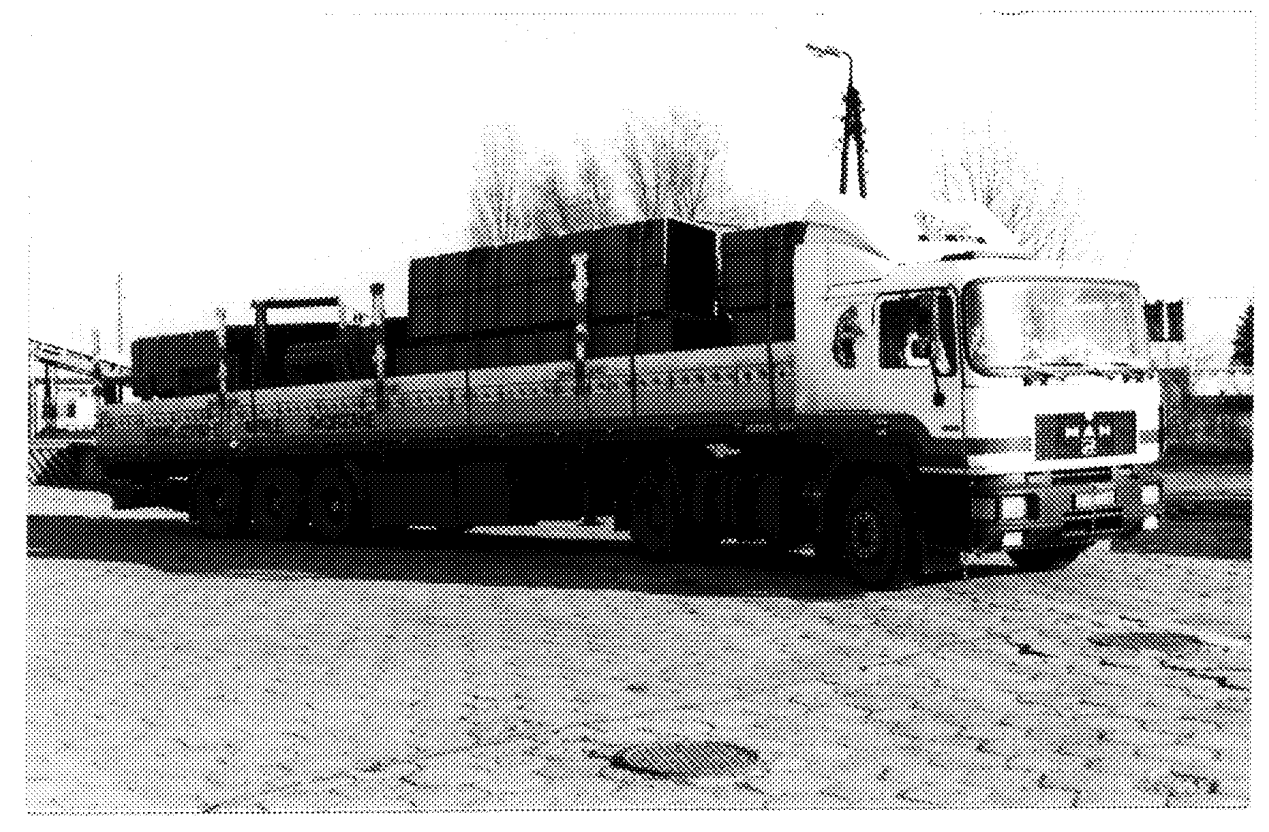

Figure 30. Equipment Being Shipped from Ecolnstal 
DE-FC22-94PC94111

\subsection{Difficulties/Problems Encountered During this Project}

During the course of this project, a number of challenges were faced by American firms which added to the complexity and difficulty of achieving goals. Most of these challenges were due to a rapidly changing business culture during a period of post-communist political change. In the early 1990s, there were many large state-owned companies throughout Poland, most of them bloated and inefficient by western standards. And while substantial improvements have occurred in Poland since 1989, the early 1990s was a period of substantial change. Some of the problems that were encountered while implementing this project are summarized below:

1. Environmental standards for air and water discharges from the Ministry of the Environment in Poland were promulgated in 1990 and contain regulations for particulate and gaseous emissions. Even though particulates are considered a "priority pollutant," the Polish emission standard for coal-fired grate boilers is $600 \mathrm{~g} / \mathrm{GJ}$, which is roughly ten times higher than that of neighboring countries such as the Czech Republic. These regulations are also written in a way that allows considerable discretion and flexibility on the part of regulating authorities. Such discretion inevitably leads to inconsistent and even arbitrary decisions and rulings by local enforcement officials. It also promotes the continuation of strong central planning, rather than through the reliance of a free market. During this period, regulatory involvement has not been consistent and uniform, where all sources are held responsible for meeting their specific targets.

2. During the course of this project, LSR and its Polish partner made several proposals for emission control systems on boilerhouses in Krakow. A number of these seemed to be promising, but were declined at the last moment when an artificially low price was offered to convert to natural gas or to the district heating system. The volatility and uncertainty of fuel prices were difficult to deal with from the standpoint of suppliers of environmental and energy-related equipment. 
3. The business climate in Krakow is more difficult than other regions of the country. This observation is evidenced by the fact that 40 Core Separator dust collectors were sold in other Polish cities without the benefit of subsidies. At the same time, only four systems were sold in Krakow despite a 50 percent subsidy incentive and a more concentrated effort. A commonly held belief is that Krakow businesses have come to expect full subsidies from either U.S. or E.U. sources. 
DE-FC22-94PC94111

\subsection{Summary and Conclusions}

The objective of the Krakow Clean Fuels and Energy Efficiency Program was the formation of business ventures between U.S. and Polish firms to reduce air emissions in the city of Krakow. The cooperative agreement between LSR Technologies, Inc. and EcoInstal is a longterm self-sustaining venture whereby modern U.S. technology can be offered commercially in Poland through a free-market mechanism. This project has been able to claim the following accomplishments consistent with U.S./Polish goals and objectives:

- Creation of a mutually beneficial business venture between a Polish and U.S. firm which will sustain itself on a continuing basis

- Installation of five (5) Core Separator installations in Krakow as well as many other nearby units all of which improve air quality in this historic city

- Installation of forty-five (45) Core Separator installations throughout Poland with a combined capacity of 1.7 million $\mathrm{M}^{3} / \mathrm{h}$ (1.0 million acfm)

- A reduction of particulate emissions in Krakow of more than 115 metric tons per year and a reduction of more than 2,150 metric tons per year throughout Poland

- Introduction of a new technology to a Polish firm, enabling that firm to grow substantially and triple its employee work force

- An added benefit to the Polish firm of exporting equipment out of the country, creating jobs for the local economy, while having a positive effect on the Polish trade balance. 


\section{Acknowledgment}

The authors would like to thank the Department of Energy and Agency for International Development for supporting this project. The Krakow Clean Fuels and Energy Efficiency

Program has definitely made a difference in that city and has brought about a betterment for the entire region. The authors would also like to recognize Mr. Douglas Gyorke for his invaluable support to this and the other Krakow projects. Doug spent almost as much time in Poland as a diplomat, and made vital contributions to the success of the Krakow projects. 
DE-FC22-94PC94111

\section{APPENDIX}


DE-FC22-94PC94111

\subsection{Sprawozdanie}

Oczyszczanie środowiska i kontrola wyziewów przemysłowych mają obecnie priorytetową pozycję w sferze poprawy warunków życia w Polsce post-komunistycznej. Poważne zanieczyszczenie powietrza, wody i gleby na terenie całego kraju jest wynikiem ponad czterech dekad centralnego planowania gospodarką. Zanieczyszczenia te sq powodem obniżenia zdrowia ludności. Rząd polski rozpoczał wprowadzanie kontroli środowiska w celu odwrócenia tej sytuacji. Polski przemysi węglowy jest jednym z przedmiotów tej kampanii. W roku 1990 wẹgiel kamienny ciągle jeszcze był źródłem około 80-ciu procent podstawowej produkcji energii elekrycznej. Użytkowanie wẹgla w Polsce jest jeszcze bardzo niewydajne. Polska zużywa 2 do 3 razy wiecej energii na jednostkp̧ brutto produkcji krajowej (GDP) w porównaniu to krajów Europy Zachodniej.

Firma LSR Technologies została wybrana przez Dwustronny (Amerykańsko-Polski) Komitet Sterujący jako jedna $x$ partycypantów Krakowskiego Programu Czystych Paliw Kopalnianych i Oszczędności Energii, aby wziąé udzial w jednym z pięciu zakresów projektu wstępnego tego programu. Wybrany zakres tegoż projektu skupił się na ograniczeniu emisji pyłów z kotłowni węglowych i koksowych za pomocą nowej technologii odpylników, pod nazwą Core Separator ${ }^{\mathrm{TM}}$ (separator/oddzielacz rdzeniowy). Ponieważ Core Separator jest przyrządem bardziej opłacalnym i o wiele wydajniejszym od cyklonów wielostopniowych, zauważono, że byłby on doskonałym rozwiązaniem dla bardzo w Krakowie rozproszonych źódel wydzielaczy pyłow. Na początku lat 90-tych Kraków miał jeszcze około 1300 kotlowni zawierajacych około 2900 kotlów ogrzewczych. Pomimo że od tego czasu wiele $z$ tych kotłowni zamknięto, poważna jednak ich część pozostaje jeszcze w eksploatacji i stanowi główne źródlo emisji pyłow do atmosfery.

W 1994 roku firma LSR Technologies podpisała umowę o współpracy, z podziałem 
DE-FC22-94PC94111

kosztow, z Departamentem Energetyki USA. Umowa ta zapewniała oprzyrządowanie, obsługe $i$ serwis związane $z$ zainstalowaniem systemów do ograniczania emisji zanieczyszczeń powietrza z kotłowni węglowych. Stworzony został dwufazowy projekt, którego zadania podzielono na dwie ścisle okresłone struktury. Pierwsza faza zawierała badania infrastruktury na ktore składaly się: (1) opracowanie planu przedsięwzięcia i strategii rynkowej; (2) analiza i wybór partnera do produkcji i obsługi spodziewanego zapotrzebowania rynku, oraz (3) zabezpieczenie odpowiednich środków finansowych oraz zapewnienie zobowiązaí o podziale kosztów na pierwsze instalacje. Do wykonania tej fazy firma LSR weszła w umowę z Fundacją Na Rzecz Efektywnego Wykorzystania Energii w celu uzyskania pomocy w ogólnym planowaniu oraz w wykonaniu prac. Pod koniec pierwszej fazy projektu polska firma Ecolnstal została zatrudniona jako główny partner LSR Technologies.

Druga faza objęła zabezpieczenie poważniejszych zobowiązá finansowych do właściwego wdrożenia $i$ instalacji nowej technologii $w$ kotłowniach węglowych. Miejscem pokazowym dla zainstalowania pierwszego zespołu Core Separator zostały wybrane Krakowskie Zakłady Armatur, gdzie usprawniono kolektor pyłu w kotle typu WR-5. Cztery (4) kolejne zespoty Core Sepanator zainstalowano w innych kotłowniach Krakowa. W kazdej z nich skutecznośc kolektorów pyłu wzrosła z 75-80\% do akoło 94-97\%. Poziom emisji pyłow zmalał do poniżej $20 \mathrm{~g} / \mathrm{GJ}$, co zblizyło się do wydajności droższych urządzeń, jak filtrow elektrostatycznych (ESP) lub tkaninowych. Równolegle z instalacjami w Krakowie, 40 innych zespotow Core Separator zamontowano w innych rejonach Polski, $m$. in. na Slasku, który jest jednym z głównych źródel zanieczyszczeń powietrza w Krakowie.

W celu dostosowania się do zapotrzebowania na zespoły Cone Sepanator w Polsce, konieczne stało się wyraźne powiększenie zdolności produkcyjnej Ecolnstalu. Proces usprawnienia produkcji wymagał scisłej współpracy na którą złozyły sie nastepujace zadania: (1) opracowanie oprojektowania modułowego przy użyciu techniki CAD/CAM (projektowanie układow wspomagane komputerem/produkcja wspomagana komputerem); (2) transfer 
DE-FC22-94PC94111

nowej technologii przystosowanej do polskich wymagań technicznych metalu; (3)

wypracowanie osprzętu do standardyzacji komponentów; (4) nabycie nowych

maszyn produkcyjnych, oraz (5) gruntowne szkolenie robotników. W wyniku tych wysiłkow i usprawnień EcoInstal stał się szanowanq̨ i znaną na rynku firmą produkujacą układy do kontroli zanieczyszczenia powietrza. Ecolnstal może obecnie konkurować pod względem ceny oraz jakości produktu praktycznie z każdą firmą przemyshu metalowego w Polsce.

Podezas trwania tego projektu, obie firmy, LSR jak i Ecolnstal, otrzymały prestiźowe nagrody za zespoły Core Separator. W 1996 roku LSR zdobyła nagrode R\&D 100 Award przyznawaną corocznie za najlepszy wyrób techniczny na świecie. EcoInstal zdobył w roku 1997 Polską Nagrodę za Przodownictwo w Ochronie Środowiska przyznawaną przez Ministra Ochrony Środowiska, za wyjątkowy wkład w kontrolę zanieczyszczeń.

Projekt ten okazał się olbrzymim sukcesem i wypetnił wszystkie cele postawione przez Dwustronny Komitet Sterujący. Do osiągnieć projektu, które przyczyniły się do wypełnienia powyższych celi należy zaliczyc:

- Stworzenie wzajemnie korzystnego przedsięwzięcia pomiędzy polską i amerykanską firma, które jest od tego czasu samodzielnie kontynuowane i utrzymywane;

- Zainstalowanie 5-ciu zestawów Core Separator w Krakowie oraz wielu innych w rejonie Krakowa, które przyczyniają się do znacznej poprawy jakości powietrza w tym historycznym miescie;

- Zainstalowanie 45-ciu zespołów Core Separator z łącznq wydajnościq 1.7 miliona $\mathrm{m}^{3} / \mathrm{h}$ w skali całego kraju; 
DE-FC22-94PC94111

- Obniżenie poziomu emisji pyłów w Krakowie o ponad 115 ton rocznie oraz z górą 2150 ton rocznie na terenie całej Polski;

- Zapoznanie polskiej firmy z nową technologią, umożliwiła znaczny jej rozrost oraz potrojenie liczby jej pracowników;

- Zaistnienie dla polskiej firmy możliwości eksportu osprzętu jako dodatkowego ubocznego benefitu tego projektu; sytuacja ta łączy się pośrednio ze stworzeniem nowych posad (poszerzenie rynku pracy) oraz ogólnie wpływa pozytywnie na bilans polskiego handlu zagranicznego. 
Prestiżowa nagroda ministra ochrony środowiska, zasobów naturalnych i leśnictwa

\section{Lider Polskiej Ekologii}

Protokó́ z posiedzenia Rady Programowej Konkursu Lider Polskiej Ekologii

W dniu 12.05.1997 r. odbylo sie posiedze nie Rady Programowej Konkursu "Lider Pol skiej Ekologil ${ }^{p}$ w skladzie:

przewodniczacy:

Adam Mierzwitssk - dyrektor generalny w.Ministerstwie Ochrony Srodowiska, Zasobow Naturainych I Lesnictwa,

zastepcy przewodniczacego: Ekologil Terenow Uprzemystowionych

Stanislaw Garilck - wicedyrektor Depar amentu Polityki Ekologicznei w Minister

stwie Ochrony Srodowiska, Zasobow Natu-

rainych I Lesnlctwa,

cdonkowie:

Tomasz Winnicks - Politechnika Wroclawska Instytut Inżynierii Ochrony Srodowiska Przemystaw Trolan - Muzeum i Instytut Zoologil PAN

Przemystaw Czajkowshd - koordynator kraiony GEF/SCP.

Jolanta Matlakowska Harmanisha. redakcja czasopisma "EKOPROFI"

Macle] Nowicki " - prẹzes fundacj EKOFUNDUSZ,

Westawa Bogutyn - Ministerstwo Gospodaki, Departament Przemysiu,

Waclaw Jedllíski - Ministerstwo Zdrowia i Opieki Spolecznej.

Barbara Pac-Kowalczyk - kerownik Ze spolu Przemystu Chemicznego Polskiego Contrum Badah I Certylikac|i,

Andrzej Mlloszewsld - dyrektor Zespolu Kontroll Glownego Inspektoratu, Ochrony

Srodowiska,

sekretarz:

Wanda Jarosz * Instytut Ekologl
Uprzemyslowionych:;

Na ogónopolski konkurs o tytul "Lider Polsklel Ekologit" wplynęty tacanie 162 zgloszenia w czterech kategorlach: techniks i techinologie, nauka, uslugi, edukacja ekologicana. Driesiex z nich nie spelnialo formalnych wymagán regulaminu konkursu i zostalo odrzu conych - brak formularza zgloszenia, opist ipredsiewzięcla.
W poszczególnych kategoniach zgloszono - techniki i technologie- 72 wnioski - nauka - 14 wnioskbw

- uslugi - 14 wnioskow

edukacja ekologicuna - 52 wnioska.

Po zapoznaniu sie'z trescia nadestanych prac calonkowie Rady Programowej postano will prazenac tytul LDERA POL SKIEI EKOLOCI $w$ poszczególnych kategoriach nastepujacym whioskom:

\section{Kategoria}

\section{techniki i technologie}

- .Technologia produkcjl oleju napędo wego miejskiego". Zglaszajacy: Petrochemi. Plock S.A., Plock

- Automatycany pylomierz grawimetrycz. ny P-10ZA: Zglaszajacy: BAASK - Aparatur

Pomiarowa I ZUH ZAM Kety S.A., Kety.

Trzeciej nagrody $\mathbf{w}$ kategoril technilk

- i technologie nie prayznano.

Kategoria usługi

- Kompleksowa realizacja inwestycj ochrony powietrza: projektowanie, mon taż, produkcja, serwis".

Zglaszajacy: ECO INSTAL Specjalistyczne Przedsiebiorstwo Budowy Urzadzen do Ochrony Środowiska, Poznat.

"Instalacja odsiarczania lodpylania spalin". Zglaszajacy: Fabryka Urzadzef Mechanicznych KAMAX S.A., Kaniczuga.

- Prace doradczo-projektowe.

- Kompleksowe rozwiazywanie proble mow ekologicznych w zakresie gospodark wodno-sciekowej w miescie Zglerz.

- Kompleksowe uporzadkowanie zagadnief gospodark odpadami w miescle Bolestawiec. gospodark odpadami w miescie Bolestawiec. - Kompleksowe uporządkowanie zagad - Kompleksowy regionalny program go spodarkl odpadami dia Stowarzyszenia Gmin Lubuskich Pogranicze" 4 " in

Konsulting - przeglądy ekologiczne. Konsulting - szkolenia
Zglaszajacy: Przedsiebiorstwo Projektowo -Intynieryine EKOLOG Sp. z 0.0., Pila.

\section{Kategoria nauka}

Podjeto decyzje o nieprzyznaniu nagrody "Lidera Polskiej Ekologii" w kategort nauka.

\section{Kategoria}

edukacja ekologiczna

Mikrosystem ekologiczno-wychowaw czy Zielona Szkota 1 jego realizacja w utwo rzonej Stacil Ekologicznej w' Miedzygorzu oraz w Miedzyszkolnym Centrum Edukac Prosrodowiskowej przy Zespole Szkol Chemicznych w Poznaniu", "Ogrod dydaktyczny ze stacja meteorologiczna przy Zespole Szkó Chemicznych w Poznaniu", Ochrona wod srodowiska naturalnego

Zglaszajacy: Zespoft Szkol Chemicznych I Xil Liceum Ekologiczne, Poznan

- "Czysta sprawa" - pillotażowy program edukacil ekologicznej mlasta Rzeszowa i MB-Rzeszow S.A. o zagospodarowaniu odpadów komunalnych". Zglaszaiacy MB-Rzeszow S.A., Rzeszów

-Polsko-Amerykatiski Program Edukaci Ekologiczne $K_{R A C}$. Zglaszający: Regionalne Centrum Edukacj Ekologicane; Plock

Rada Programowa wnloskuje o przyznanie specjalnej nagrody ministra ochrony stodowiska, zasobów naturainych il lesnic. twa, "Lider Polskiej Ekologil" dla pracy:

- "Harcerski Program Edukacji Ekologicz nej" Zglaszajacy: Glówna Kwatera Zwiazku Harcerstwa Polskiego, Warszawa.

Podplsat

przewodnlaxacy Rady Programowe Konkursu "Lider Polakle Ekologlt" Adam Mleraulisht Zatwierdzl minlster Stanibiaw Zelkhowih 16 mala 1997 r. 


\begin{tabular}{|c|c|}
\hline J. Ciecrishli-A. Pasaoki & 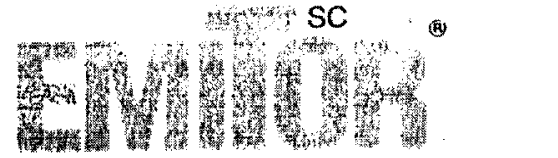 \\
\hline & $\begin{array}{l}\text { ska 123, 45-232 Opole, telfax (0-77)556037 } \\
\text { : ul. Grota Roweckiego 9a, 46-256 Opole }\end{array}$ \\
\hline
\end{tabular}

\section{BADANIA ZANIECZYSZCZEŃ POWIETRZA}

Inwestor:

Miejskie Przedsiębiorstwo Komunikacyjne

Stacja Obslugi Autobusów Kraków-Bieńczyce.

Temal opracowania:

Pomiary emisji pylowej i skuteczności odpylania

Instalacji odpylającej Kotlów WCO-80 nr.2 i 3

w MPK - Stacja Obslugi Autobusów Kraków-Bieńczyce.

Instalacje odpylania z zastosowaniem

CORE SEPARATORA wykonar:

\section{ECO-INSTAL}

Specjalistyczne Przedsiębiorstwo Budowy

Urządzeń Do Ochrony Środowiska

Zaklad produkcyjny Nr 1 w Kościanic

64-000 Kościan ul. Ląkowa 5 ..

tel. $065 / 120595$

fax $065 / 121927$

OPOLE MARZE

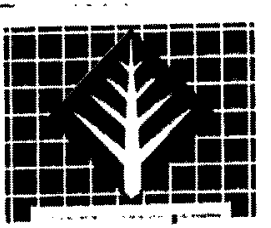

SPEGJALISTYCZIE PRZEDSEEBIORSTWO

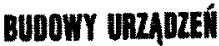

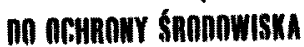


Spis treści.

1. Cel i zakres pomiarów.

2. Metodyka i aparatura pomiarowa.

2.1. Metodyka pomiaru emisji i unosu pylu.

2.2. Zestaw aparatury.

2.3. Mierzone i wyznaczane parametry.

2.4. Analiza skladu chemicznego gazu

2.5. Obliczenia emisji pylowej i skuteczności odpylania.

3. Parametry pracy urządzenia technologicznego.

4. Punkty pomiarowe.

5. Wyniki i uwagi koncowe.

6. Wydruki komputerowe wyników pomiarów i kart danych pomiarowych. 


\section{Cel i zakres pomiarów.}

Podstawą do wykonania niniejszych pomiarów jest zlecenie Eco-Instal Poznań Zakładu Produkcyjnego Nr 1 w Kościanie dotyczace wykonania pomiarów emisji pylowej i skuteczności odpylania instalacji odpylających Kotlów WCO-80 nr.2 i 3 w Kotlowni Zakladowej Miejskiego Przedsiębiorstwa Komunikacji - Stacja Obshugi Autobusów w KrakowieBieńczyce ul.Makuszyńskiego.

Cykl pomiarowy obejmowal następujące etapy prac:

Kociol WCO-80 nr.2

- za kotlem, przed cyklonem i Core Separatorem (Up)

- za cyklonem i Core Separatorem - przed wentyl. (Ep)

\section{Kociol WCO-80 nr.3}

pkt. 1 - za kotlem przed cyklonami ( Up ) pkt.2 - za cyklonami a przed odpylaczem Core Separatorem (Up).

pkt.3 - za cyklonami i za odpylaczem Core Separatorem - przed wentyl. (Ep)

pkt.4 - za cyklonami i za odpylaczem Core Separatorem - za wentyl. ( Np )

pkt.5 - na kanale recyrkulacyjnym przed wentylatorem ( $\mathrm{Np}$ )

pkt.6 - na kanale recyrkulacyjnym za wentylatorem (Up)

$$
\begin{array}{ll}
\text { Up } & \text { - pomiar unosu pylu } \\
\text { Ep } & \text { - pomiar emisji pyłu } \\
\mathrm{Np} & \text { - pomiar natężenia przeplywu }
\end{array}
$$

\section{Metodyka i aparatura pomiarowa.}

\subsection{Metodyka pomiaru emisji pylu i skuteczności odpylania.}

Pomiar natężenia przepływu gazu i stężenia zapylenia za urządzeniem odpylającym przeprowadzono stosownie do zaleceń „Katalogu Metod Manualnych " Etap 11 - Emisja oraz Polskiej Normy PN-Z-04030-7 „Ochrona czystosci powietrza. Badania zawartości pyłu. Pomiar stężenia i strumienia masy pylu w gazach odlotowych metoda grawimetryczna".

\subsection{Zestaw aparatury:}

- sondy zmodernizowane i zerowe, ogrzewane z końcówkami $\varnothing 13 \mathrm{~mm}$

- filtr mierniczy ogrzewany $z$ filtrem tkaninowym

- chlodnica

- absorber wypeiniony $\mathrm{CaCl}_{2}$

- rurka spiętrzająca Prandtla - liczba ksztaltu $\beta=1,00$ 
- gazomierz wyposażony w termometr i manometr

- pompa ssąca

- mikromanometr typu MPR-4 wypelniony etanolem o gęstości $\gamma=0,8 \mathrm{~g} / \mathrm{cm}^{3}$

- mierniki temperatury typu EMT-07

- wskażniki quasiizokinetyczności

- barometr ze skalą mosiężną i termometr rtęciowy

- komplet węży gumowych $\varnothing 13 \mathrm{~mm}$

- komplet węży gumowych impulsowych $\varnothing 3 \mathrm{~mm}$.

\subsection{Mierzone i wyznaczane parametry / jednostka /}

- ciśnienie barometryczne

$/ \mathrm{mmHg}, \mathrm{hPa} /$

- temperatura otoczenia

$1{ }^{\circ} \mathrm{C}, \mathrm{K} /$

- wymiary kanalu pomiarowego $/ \mathrm{mm}, \mathrm{m}^{2} /$

- zanurzenic sondy pomiarowej w kanale / $/ \mathrm{mm} /$

- założenie stalej wielkości czasu do zassania czesściowego strumienia gazu w każdym punkcie pomiaru / $/ \mathrm{min} /$

- temperatura gazu w gazomierzu $\quad 1^{\circ} \mathrm{C}, \mathrm{K} /$

- temperatura gazu $w$ kanale pomiarowym $/{ }^{\circ} \mathrm{C}, \mathrm{K} /$

- podciśnienie w gazomierzu $/ \mathrm{mmHg}, \mathrm{Pa} /$

- ciśnienie dynamiczne w kanale $/ \mathrm{mmC}_{2} \mathrm{H}_{5} \mathrm{OH}, \mathrm{Pa} /$

- ciśnienie statyczne $w$ kanale $/ \mathrm{mmC}_{2} \mathrm{H}_{3} \mathrm{OH}, \mathrm{mmH}_{2} \mathrm{O}, \mathrm{Pa} /$

- pomiar zerujący / utrzymanie równowagi ciśnień statycznych w kanale i glowicy sondy $\mathbf{z}$ uwzględnieniem oporów hudraulicznych i stopnia rozprężenia gazu /

- ilość wykroplonej pary wodnej w chlodnicy /g/

- ilość zaabsorbowanej pary wodnej w absorberze $/ \mathrm{g} /$

- wielkość częściowego strumienia gazu suchego $/ \mathrm{m}^{3} /$

\subsection{Analiza skladu chemicznego gazu i stężenia tlenku węgla.}

Analiza skladu chemicznego gazu, oznaczenie \% zawartości $\mathrm{CO}_{2}, \mathrm{O}_{2}$ i zawartości $\mathrm{CO} w$ ppm przeprowadzono przy pomocy analizatora gazu z czujnikami elektrochemicznymi typu TESTO-342-1.

\subsection{Obliczenie emisji pylu i skuteczności odpylania.}

Obliczenia wyników z przeprowadzonych prac pomiarowych wykonano przy pomocy programu komputerowego „EMISJA 5.1" autorstwa mgr inż Ryszard Samoć - Zaklad Ushug Komputerowych Dla Potrzeb Ochrony Środowiska $62-800$ Kalisz.

\section{Parametry pracy urzadzeń teclinologicznych.}

Pomiary emisji pylowej i skuteczności odpylania wykonano przy następujących parametrach pracy kotlow WCO-80 nr.2 i 3. 


\begin{tabular}{|l|c|c|c|}
\hline \multicolumn{1}{|c|}{ Parametr mierzony } & Jednostka & \multicolumn{2}{c|}{ Wartość } \\
\hline & & Kociol nr.2 & Kociol nr.3 \\
\hline Temperatura wody z kotla & ${ }^{\circ} \mathrm{C}$ & 120 & 118 \\
\hline Temperatura wody do kotla & ${ }^{\circ} \mathrm{C}$ & 73 & 75 \\
\hline Ciśnienie wody na kotle & $\mathrm{MPa}$ & 0,19 & 0,19 \\
\hline
\end{tabular}

Rodzaj paliwa: mial weglowy

$\begin{array}{ll}\text { kaloryczność } & -20000 \mathrm{~kJ} / \mathrm{kg} \\ \text { zawartość popiolu } & -21 \% \\ \text { zawartość siarki } & -1,0 \%\end{array}$

\section{Punkty pomiarowe.}

llość krócców pomiarowych zainstalowanych na instalacji odpylającej kotlów WCO-80 jest zgodna z zaleceniami Polskiej Normy PN-Z-04030-7 „Ochrona czystości powietrza. Badania zawartości pylu. Pomiar stężenia i strumienia masy pylu w gazach odlotowych metoda grawimetryczną" a ich usytuowanie jest optymalne do istniejacego ksztaltu instalacji. Usytuowanie punktów pomiarowych przedstawiono poniżej: (dhugość odciṇka prostego przed pkt. pom./ za pkt. pom. w metrach ).

Ksztalt instalacji na obydwuch kotlach WCO-80 jest ten sam.
za kotlem przed cyklonami
za cyklonami a przed odpyl. Core Separatorem
$-(0,2 / 0,6)$
za cylomi
$-(0,3 / 0,1)$
kanal recyrkulacyjny - przed wentylatorem
$-(0,5 / 1,0)$
kanal recyrkulacyjny - za wentylatorem
- $(0,9 / 0,4)$
$-(0,7 / 0,5)$
za cyklonami i za odpyl. Core Separatorem przed wentyl. ciagu
$-(0,6 / 0,2)$

\section{Wyniki i uwagi końcowe.}

W poniższych tabelach i wykresach przedstawiono wyniki pomiarów.

\section{Wykres natężenie przeplywu dla kotlów WCO-80 nr.2 i $3 / \mathrm{w} \mathrm{m}^{3} / \mathrm{h} /$}

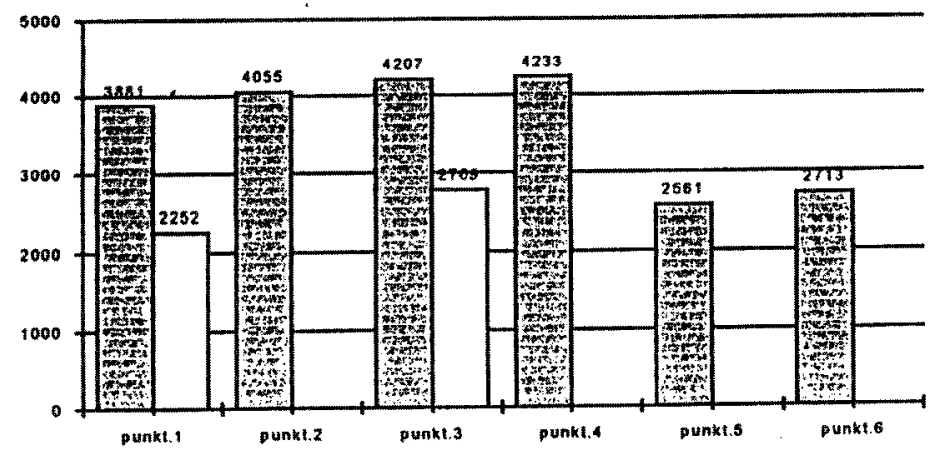


Zestawienie wyników pomiarów na kotle WCO-80 nr.2

\begin{tabular}{|c|c|c|c|c|c|c|}
\hline \multirow{2}{*}{$\begin{array}{c}\text { Miejsce } \\
\text { pomiaru }\end{array}$} & $\begin{array}{c}\text { Temp. } \\
\text { spalin }\end{array}$ & $\begin{array}{c}\text { Ciśnienie } \\
\text { stalyczna }\end{array}$ & $\begin{array}{c}\text { Ciśnienie } \\
\text { dynamiczne }\end{array}$ & $\begin{array}{c}\text { Natężenie } \\
\text { przepływu }\end{array}$ & $\begin{array}{c}\text { Stężenie } \\
\text { pyłu }\end{array}$ & $\begin{array}{c}\text { Unos } \\
\text { pylu }\end{array}$ \\
\cline { 2 - 7 } & ${ }^{\circ} \mathrm{C}$ & $\mathrm{Pa}$ & $\mathrm{Pa}$ & $\mathrm{Nm}^{3} / \mathrm{h}$ & $\mathrm{mg} / \mathrm{Nm}^{3}$ & $\mathrm{~kg} / \mathrm{h}$ \\
\hline Punkt.1 & 139 & -2667 & 6 & 2479 & 873,5 & 2,164 \\
\hline Punkt.2 & 63 & -4001 & 23 & 2769 & 67,3 & 0,186 \\
\hline
\end{tabular}

Schemat instalacji odpylającej kotla WCO-80 nr. 2 wraz z wynikami.

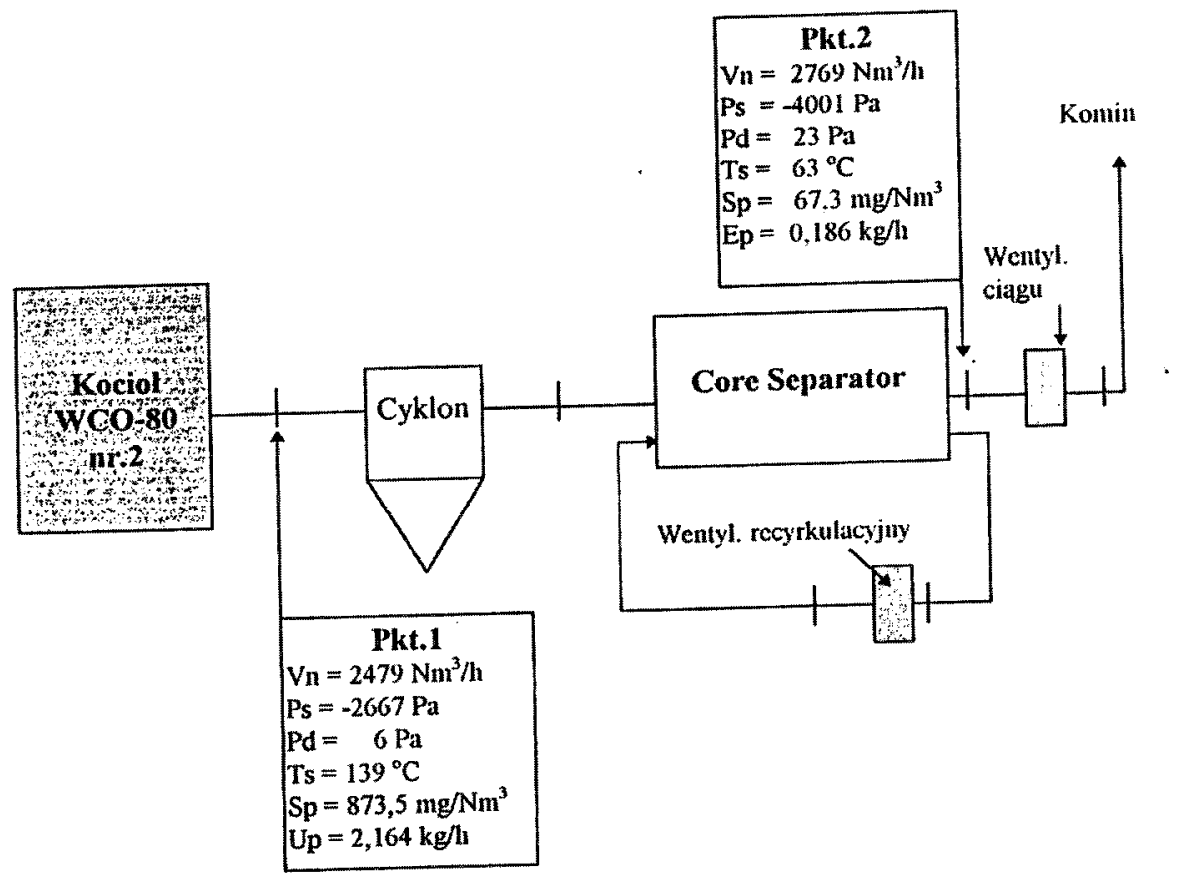

Zestawienie wyników pomiarów na kotle WCO-80 nr.3

\begin{tabular}{|c|c|c|c|c|c|c|}
\hline $\begin{array}{l}\text { Miejsce } \\
\text { pomianu }\end{array}$ & $\begin{array}{l}\text { temp } \\
\text { spalin }\end{array}$ & $\begin{array}{l}\text { Cisniene } \\
\text { statyczna }\end{array}$ & $\begin{array}{l}\text { Clsniene } \\
\text { dynamiczne }\end{array}$ & $\begin{array}{l}\text { Natezenie } \\
\text { przeplywu }\end{array}$ & $\begin{array}{l}\text { Steztenie, } \\
\text { pytu }\end{array}$ & $\begin{array}{l}\text { Unos } \\
\text { pylu }\end{array}$ \\
\hline H.t, & $\therefore{ }^{\circ} \mathrm{C}$ & $\mathrm{Pa}$ & $\mathrm{Pa}$ & $\mathrm{Nm}^{3} / \mathrm{h}$ & $\mathrm{mg} / \mathrm{Nm}^{3}$ & $\mathrm{~kg} / \mathrm{h}$ \\
\hline Punkt.1 & 130 & -1015 & 12 & 3881 & 793,0 & 3,078 \\
\hline Punkt. 2 & 120 & -1218 & 69 & 4055 & 372,4 & 1,510 \\
\hline Punkt 3 & 72 & -2593 & 56 & 4207 & 28,9 & 0,122 \\
\hline Punkt. 4 & 72 & -70 & 13 & 4233 & - & $=$ \\
\hline Punkt. 5 & 59 & -1471 & 44 & 2561 & - & - \\
\hline Punkt.6 & 59 & -1243 & 50 & 2713 & 350,1 & 0,950 \\
\hline
\end{tabular}


Schemat instalacji odpylającej kotla WCO-80 nr.3 wraz z wynikami.

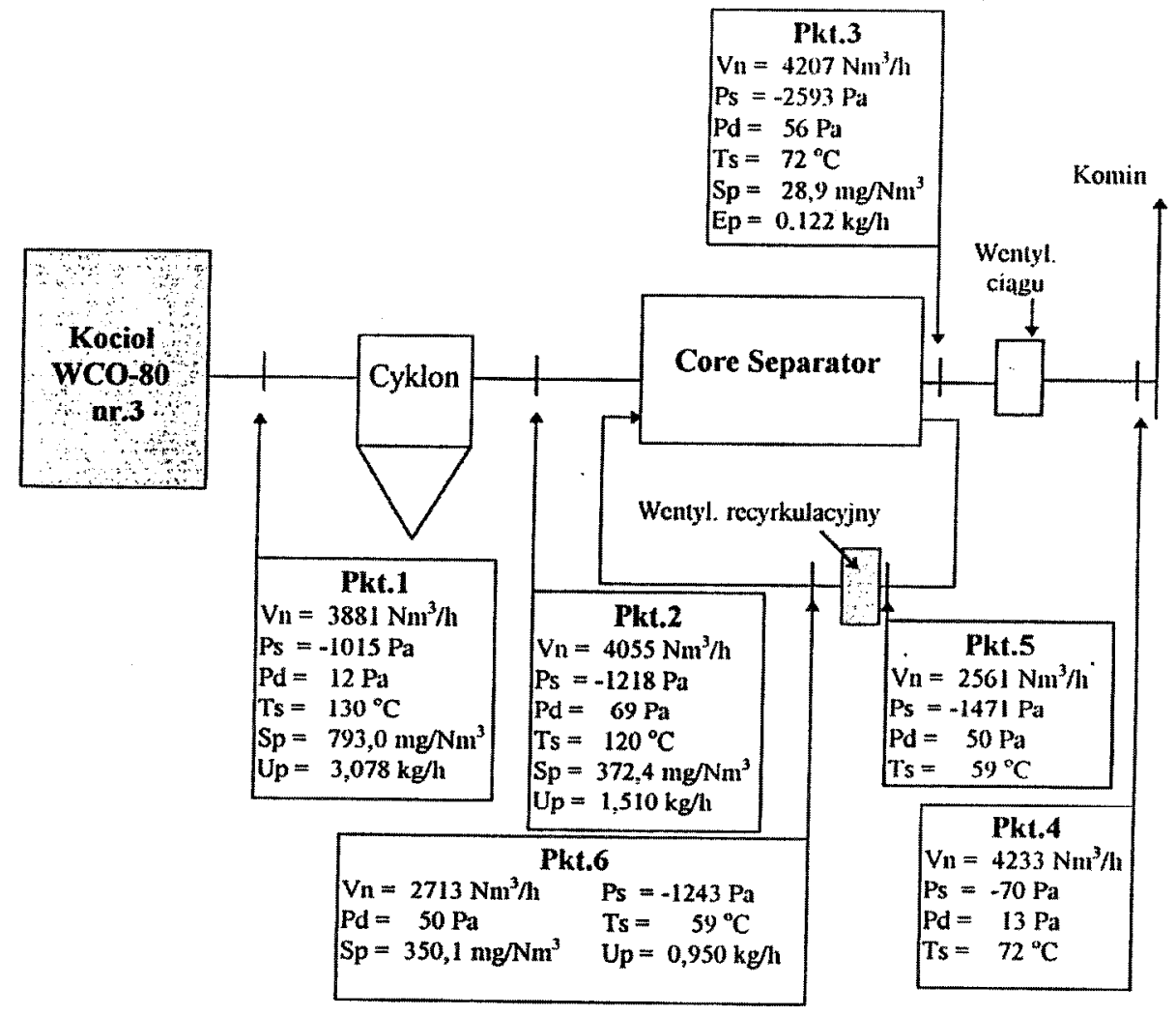

Wykres unosu i emisji pylu kotlów WCO-80 nr.2 i 3 - w kg/h

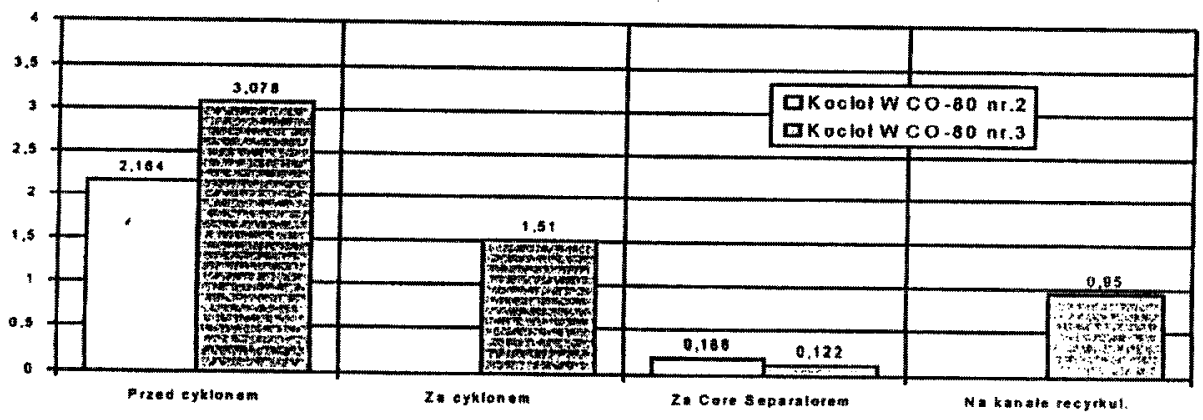

Skuteczność odpylania zespolu urządzeń odpylających kotla WCO-80 nr.2 (cyklony + Core Separator) $\quad$ So $=91,39 \%$ 
Wyniki pomiarów skuteczności odpylania zespolu odpylającego kotla WCO-80 nr.3

\begin{tabular}{|l|c|}
\hline $\begin{array}{c}\text { Urządzenie } \\
\text { odpylające }\end{array}$ & $\begin{array}{c}\text { Skuteczność } \\
\text { odpylania w \% }\end{array}$ \\
\hline Cyklon & 50,9 \\
\hline Core Separator & 91,9 \\
\hline Cyklon + Core Separator & 96,0 \\
\hline
\end{tabular}

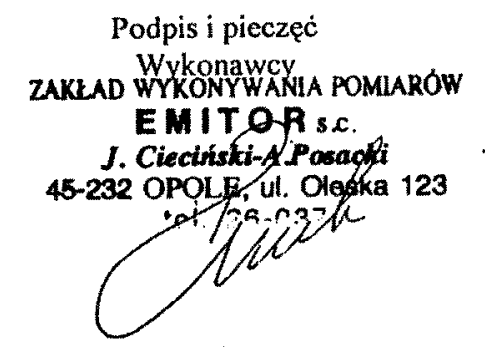


Zakiad Hykonywania Poniarók

'BHITOR" s.c.

45-232 Opole, ul. Oleska 123

WYNIKI POMIARU UNOS U n $196 \mathrm{p} / \mathrm{E} / 96$

Nazwa zakładu:

Nazwa obiektu:

MPK - Stacja Obsługi Autobusów Bienczyce-Kraków

Miejsce pomiaru:

Data pomiaru

Kociol WCO-80 nr.2

Punkt nr.1 - za kotłem (przed odpylaczami)

1996-03-13

Wymiary kanału: przekrój prostokatny $0.530 \times 0.550 \mathrm{~m}$

\begin{tabular}{|r|c|c|c|c|c|}
\hline Lp & pa $x$ a m t $r$ & $j . \mathrm{m}$. & 1 & 2 & srednia \\
\hline 1 & Cisnienie barometrycz. & $\mathrm{hPa}$ & 991.94 & 991.94 & 991.94 \\
2 & Cisnienie statyczne & $\mathrm{hPa}$ & 965.27 & 965.27 & 965.27 \\
3 & Temperatura kanale & $\mathrm{K}$ & 411.5 & 412.2 & 411.85 \\
4 & Cisnienie dynamiczne & $\mathrm{Pa}$ & 5.5337 & 5.855 & 5.6944 \\
5 & Gestosc w war.umownych & $\mathrm{kg} / \mathrm{m} 3$ & 1.2905 & 1.2926 & 1.2915 \\
6 & Gestosc w war.rzeczyw. & $\mathrm{kg} / \mathrm{m} 3$ & 0.8173 & 0.8172 & 0.8173 \\
7 & Predkosc gazów & $\mathrm{m} / \mathrm{s}$ & 3.6798 & 3.7853 & 3.7326 \\
8 & Nateż. przepływu umown. & $\mathrm{m3} / \mathrm{h}$ & 2445.7 & 2511.6 & 2478.7 \\
9 & Natęz. przepływu rzecz. & $\mathrm{m3} / \mathrm{h}$ & 3861.6 & 3972.3 & 3917 \\
& Stężenie pylu & & & & \\
10 & -w warunkach rzeczyw. & $\mathrm{mg} / \mathrm{m} 3$ & 568.19 & 535.66 & 551.93 \\
11 & -w warunkach umownych & $\mathrm{mg} / \mathrm{m} 3$ & 898.54 & 848.54 & 873.54 \\
12 & Unos pylu & $\mathrm{kg} / \mathrm{h}$ & 2.1976 & 2.1312 & 2.1644 \\
\hline
\end{tabular}


Zakiad hykonyuania Poaiarón

'BHITOR' s.c.

45-232 Opole, UL. Oleska $12 \mathrm{~J}$

W Y N I K I P O M I A R U E M I S J I nI 1972/E/96

\begin{tabular}{|c|c|c|c|c|c|c|}
\hline \multicolumn{2}{|c|}{$\begin{array}{l}\text { Nazwa zakładu: } \\
\text { Nazwa obiektu: } \\
\text { Miejsce pomiaru: } \\
\text { Data pomiaru } \\
\text { Wymiary kanału: }\end{array}$} & \multicolumn{5}{|c|}{$\begin{array}{l}\text { MPK - Stacja obsługi Autobusów Bienczyce-Kraków } \\
\text { Kocioł wCo-80 nr. } 2 \\
\text { punkt nr. } 2 \text { - za odpylaczami (przed wentyl.) }\end{array}$} \\
\hline $\mathrm{Lp}$ & $\mathrm{p} a \mathrm{r}$ a $\mathrm{me}$ & $t r$ & j.m. & 1 & 2 & red \\
\hline $\begin{array}{l}1 \\
2 \\
3 \\
4 \\
5 \\
6 \\
7 \\
8 \\
9\end{array}$ & $\begin{array}{l}\text { Cisnienie barom } \\
\text { Cisnienie staty } \\
\text { Temperatura w } \\
\text { Cisnienie dynam } \\
\text { Gestost w war.u } \\
\text { Gestost w wax. } \\
\text { Predkosc gazów } \\
\text { Nateż. przepływ } \\
\text { Natez. przepływ } \\
\text { Stezenie pylu } \\
\text {-w warunkach } \\
\text {-w warunkach } \\
\text { Emisja pylu }\end{array}$ & $\begin{array}{l}\text { netrycz. } \\
\text { czne } \\
\text { canale } \\
\text { niczne } \\
\text { mownych } \\
\text { czeczyw. } \\
\text { nu umown. } \\
\text { gu rzecz. } \\
\text { rzeczyw. } \\
\text { umownych }\end{array}$ & $\begin{array}{l}\mathrm{hPa} \\
\mathrm{hPa} \\
\mathrm{K} \\
\mathrm{Pa} \\
\mathrm{kg} / \mathrm{m}^{3} \\
\mathrm{~kg} / \mathrm{m} 3 \\
\mathrm{~m} / \mathrm{s} \\
\mathrm{m} 3 / \mathrm{h} \\
\mathrm{m} 3 / \mathrm{h} \\
\ddots \\
\mathrm{mg} / \mathrm{m} 3 \\
\mathrm{mg} / \mathrm{m} 3 \\
\mathrm{~kg} / \mathrm{h}\end{array}$ & $\begin{array}{c}991.94 \\
951.93 \\
336.3 \\
24.2656 \\
1.2844 \\
0.9816 \\
7.0313 \\
2793.5 \\
3655.2 \\
51.9034 \\
68.0202 \\
0.19\end{array}$ & $\begin{array}{c}991.94 \\
951.93 \\
336.1 \\
23.4159 \\
1.2859 \\
0.9833 \\
6.9012 \\
2743.4 \\
3587.5\end{array}$ & $\begin{array}{l}991.94 \\
951.93 \\
336.2 \\
23.8408 \\
1.2851 \\
0.9825 \\
6.9662 \\
2768.5 \\
3621.4\end{array}$ \\
\hline
\end{tabular}

Błędy pomiarów fizykochemicznych $i$ analiz

bład pomiaru temperatury

błąd oznaczenia wilgotnosci gazu

bład oznaczenia gestosci gazu

bomiaru przepływu gazów $w$ kanale $=5.2 \%$

błąd oznaczenia stęźenia pyłu $=5.39 \%$

ZBSTAWIENIB BEEDÓW POMIAROW RMISJI

\begin{tabular}{|l|c|c|c|c|}
\hline nazwa zanieczyszczenia & $\begin{array}{c}\text { srednia emisja błąd względny } \\
{[\mathrm{kg} / \mathrm{h}]}\end{array}$ & $\begin{array}{c}\text { błąd bezwzgledny } \\
{[\mathrm{kg} / \mathrm{h}]}\end{array}$ \\
\hline pyl & 0.186 & 7.49 & $\mathrm{e}$ & 0.014 \\
\hline
\end{tabular}

Obliczenie sprawnosci urządzeń oczyszczających

Zakład: MPK - Stacja Obsługi Autobusów Bienczyce-Kraków

Obiekt: Kociol WCO-80 nr. 2

Pomiar emisji w dniu 1996-03-13

\begin{tabular}{|l|r|r|c|}
\hline Nazwa zanieczyszczenia & unos $\mathrm{kg} / \mathrm{h}$ & emisja $\mathrm{kg} / \mathrm{h}$ & $\begin{array}{l}\text { sprawnósé } \\
\text { oczyszcz }\end{array}$ \\
\hline pyl & 2.1644 & 0.1864 & 91.4 \\
\hline
\end{tabular}

Pomiary przed urzadzeniami oczyszczajacymi:

1.Punkt nr.1 - za kotłern (przed odpylaczami)

Pomiary za urzadzeniami oczyszczajacymi:

1 punjet nr? - >a ndprifarzami inrzed wentyl 
Zakiad Nykonywania Poniarów 'BHITOR" s.C.

15.232 Opole, v1. Oleska 123

W Y N I K I P O M I A R U U N O S U nr $189 \mathrm{p} / \mathrm{E} / 96$

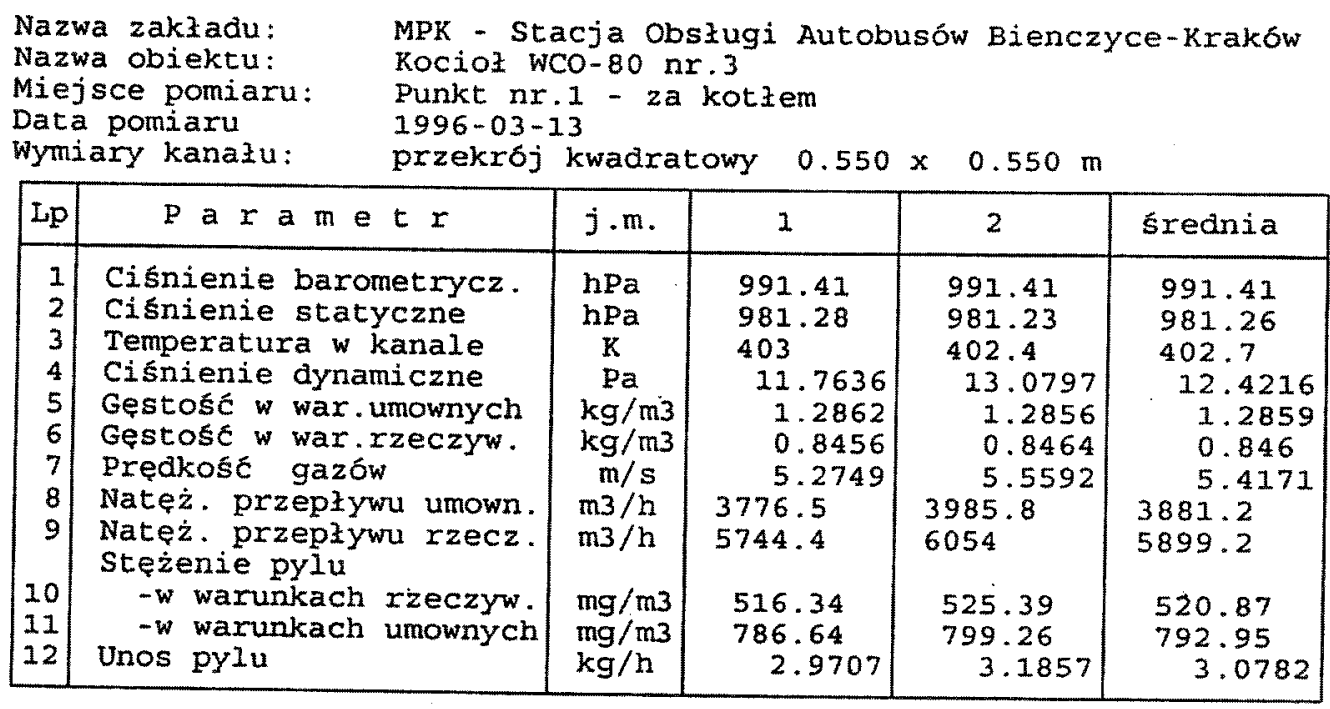


Zaklad Rykonywania Pomiaróx

'BMITOR' S.C.

45-232 Opole, vi. Oleska 123

W Y N I K I P O M I A R U E M I S J I nI 192z/E/96 $\begin{array}{ll}\text { Nazwa zakładu: } & \text { MPK - Stacja Obsługi Autobusów Bienczyce-Kraków } \\ \text { Nazwa obiektu: } & \text { Kocioł WCO-80 nr.3 } \\ \text { Miejsce pomiaru: } & \text { Punkt nr.3 - Za odpylaczami (przed wentylatorem) } \\ \text { Data pomiaru } & 1996-03-13\end{array}$

Wymiary kanału: przekrój kwadratowy $0.380 \times 0.380 \mathrm{~m}$

\begin{tabular}{|c|c|c|c|c|c|}
\hline$L p$ & $p$ a $r$ a $m$ e $t r$ & j.m. & 1 & 2 & srednia \\
\hline 1 & Cisnienie barometrycz. & $\mathrm{hPa}$ & 992.07 & 992.07 & 992.07 \\
\hline 2 & Cisnienie statyczne & $\mathrm{hPa}$ & 966.2 & 966.07 & 966.14 \\
\hline 3 & Temperatura $w$ kanale & $\mathrm{K}$ & 345.3 & 344.5 & 344.9 \\
\hline 4 & Ciśnienie dynamiczne & $\mathrm{Pa}$ & 56.7896 & 54.5922 & 55.6909 \\
\hline 5 & Gestosé w war.umownych & $\mathrm{kg} / \mathrm{m}_{3}$ & 1.2869 & 1.2856 & 1.2862 \\
\hline 6 & Gestosc w war.rzeczyw. & $\mathrm{kg} / \mathrm{m}_{3}$ & 0.9723 & 0.9734 & 0.9728 \\
\hline 7 & Predkose gazów & $\mathrm{m} / \mathrm{s}$ & 10.8083 & 10.591 & 10.6997 \\
\hline 8 & Natęz. przepływu umown. & $\mathrm{m} 3 / \mathrm{h}$ & 4244.9 & 4168.6 & 4206.8 \\
\hline 9 & $\begin{array}{l}\text { Natęz. przepływu rzecz. } \\
\text { steżenie pylu }\end{array}$ & $\mathrm{m} 3 / \mathrm{h}$ & 5618.6 & 5505.6 & 5562.1 \\
\hline 10 & -w warunkach rzeczyw. & $\mathrm{mg} / \mathrm{m}^{3}$ & 21.2122 & 22.5017 & 21.8569 \\
\hline 11 & -w warunkach umownych & $\mathrm{mg} / \mathrm{m} 3$ & 28.1213 & 29.7658 & 28.9436 \\
\hline 12 & Emisja pylu & $\mathrm{kg} / \mathrm{h}$ & 0.1194 & 0.1241 & 0.1217 \\
\hline
\end{tabular}

Błedy pomiarów fizykochemicznych $i$ analiz

błąd pomiaru temperatury

bład oznaczenia wilgotnosci gazu

bład oznaczenia gestostoi gazu

błą pomiaru przepływu gazów wanale $=5.2 \%$

błąd oznaczenia stężenia pyłu $=5.39 \%$

ZESTAWIENIB BEß̧DÓW POMIARÓW BMISJI

\begin{tabular}{|c|c|c|c|}
\hline nazwa zanieczyszczenia & $\underset{[\mathrm{kg} / \mathrm{h}]}{\text { sredinia emisja }}$ & $\underset{[\because]}{\text { błąd wzgledny }}$ & $\underset{[\mathrm{kg} / \mathrm{h}]}{\mathrm{b} \text { ąd bezwzględny }}$ \\
\hline pyl & 0.122 & 7.49 & 0.0091 \\
\hline
\end{tabular}




\section{KARTA DANYCH POMIAROWYCH $\mathrm{nr} 196 \mathrm{p} / \mathrm{E} / 96$}

Nazwa zakladu: MPK - Stacja Obsługi Autobusów Bienczyce-Kraków Nazwa obiektu: Kocioł WCO-80 nr.2

Miejsce pomiaru: Punkt nr.1 - za kotłem (przed odpylaczami)

Data pomiaru 1996-03-i3

POMIAR 1

$\begin{aligned} \text { Cisnienie barometryczne } & =991.9 \mathrm{hPa} 744.2 \mathrm{mmHg} \\ \text { Temperatura gazu } w \text { przewodzie } & =411.5{ }^{\circ} \mathrm{K} \quad 138.5^{\circ} \mathrm{C}\end{aligned}$

Odczyty ciśnienia statycznego i dynamicznego

piyn w mikromanometrze : etanol o gestości $0.8 \mathrm{~g} / \mathrm{cm} 3$

Gestośc płynu do pomiaru ciśnienia statycznego $13.6 \mathrm{~g} / \mathrm{cm} 3$

\begin{tabular}{|c|c|c|c|c|c|}
\hline$L p$ & $\underset{1 / 1}{n s}[\mathrm{~mm}]$ & PS $[\mathrm{Pa}]$ & $\begin{array}{l}\text { hd }[\mathrm{mm}] \\
1 / 5\end{array}$ & $\mathrm{Pd}[\mathrm{Pa}]$ & $w[\mathrm{~m} /$ \\
\hline $\begin{array}{l}1 \\
2 \\
3 \\
4 \\
5 \\
6 \\
7 \\
8 \\
9 \\
10 \\
11 \\
12 \\
13 \\
14 \\
15 \\
16 \\
17 \\
18 \\
19 \\
20 \\
21 \\
22 \\
23 \\
24 \\
25 \\
26 \\
27 \\
28 \\
29 \\
30\end{array}$ & $\begin{array}{l}-20 \\
-20 \\
-20 \\
-20 \\
-20 \\
-20 \\
-20 \\
-20 \\
-20 \\
-20 \\
-20 \\
-20 \\
-20 \\
-20 \\
-20 \\
-20 \\
-20 \\
-20 \\
-20 \\
-20 \\
-20 \\
-20 \\
-20 \\
-20 \\
-20 \\
-20 \\
-20 \\
-20 \\
-20 \\
-20\end{array}$ & 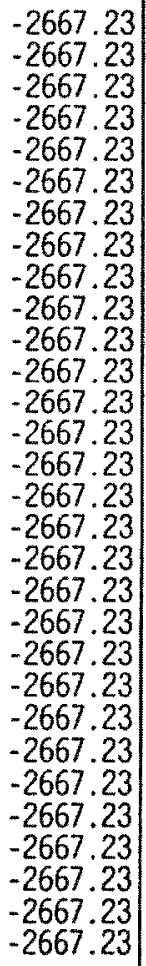 & $\begin{array}{l}0 \\
0 \\
0 \\
0 \\
0 \\
0 \\
0 \\
0 \\
0 \\
0 \\
0.5 \\
0.5 \\
0.5 \\
0.5 \\
0.5 \\
2 \\
1.5 \\
1.5 \\
2 \\
6 \\
7 \\
10 \\
10 \\
17 \\
36 \\
16 \\
22 \\
33 \\
38 \\
29\end{array}$ & $\begin{array}{c}0 \\
0 \\
0 \\
0 \\
0 \\
0 \\
0 \\
0 \\
0 \\
0 \\
0.78 \\
0.78 \\
0.78 \\
0.78 \\
0.78 \\
3.14 \\
2.35 \\
2.35 \\
3.14 \\
9.41 \\
10.98 \\
15.69 \\
15.69 \\
26.67 \\
56.48 \\
25.1 \\
34.52 \\
51.78 \\
59.62 \\
45.5\end{array}$ & $\begin{array}{l}0 \\
0 \\
0 \\
0 \\
0 \\
0 \\
0 \\
0 \\
0 \\
0 \\
1.386 \\
1.386 \\
1.386 \\
1.386 \\
1.386 \\
2.771 \\
2.4 \\
2.4 \\
2.771 \\
4.8 \\
5.184 \\
6.196 \\
6.196 \\
8.079 \\
11.756 \\
7.838 \\
9.19 \\
11.256 \\
12.079 \\
10.552\end{array}$ \\
\hline
\end{tabular}

POMIAR 2

Ciśnienie barometryczne $\quad=991.9 \mathrm{hPa} \quad 744.2 \mathrm{mmHg}$

Temperatura gazu $w$ przewodzie $=412.2^{\circ} \mathrm{K} \quad 139.2^{\circ} \mathrm{C}$

Odczyty ciśnienia statycznego i dynamicznego

\begin{tabular}{|c|c|c|c|c|c|}
\hline$L p$ & $\begin{array}{c}\text { hs }[\mathrm{mm}] \\
1 / 1\end{array}$ & $P_{S}[\mathrm{~Pa}]$ & $\begin{array}{c}\text { hd }[\mathrm{mm}] \\
1 / 5\end{array}$ & $\mathrm{Pd}[\mathrm{Pa}]$ & $w \quad[\mathrm{~m} / \mathrm{s}]$ \\
\hline
\end{tabular}




\section{INERTIAL PARTICULATE SEPARATOR FOR REDUCTION OF LES EMISSIONS IN KRAKOW}

\author{
S. Ronald Wysk \\ LSR Technologies, Inc. \\ Acton, MA U.S.A. \\ Jan Surowka \\ Polish Foundation for Energy Emiciency \\ Katowice, Poland
}

\section{Introduction}

Environmental clean-up and pollution control are considered foremost national priorities in Poland. More than four decades of centralized planning has produced serious contamination of air, water, and soil throughout the country and a resulting deterioration of public health As a result, life expectancy is lower today than it was 20 years ago. Also, incidents of serious disease in adults and young children there have been on the rise. It is therefore, imperative that corrective action be taken.

The government of Poland has begun to implement strong environmental controls to reverse this condition. The target of these controls is the Polish coal industry, which currently comprises over $78 \%$ of primary energy production (65\% hard coal and $13 \%$ lignite). The coal utilization, especially in low grade coals, is highly inefficient. For example, Poland uses almost three times as much energy as Western Europe per unit of gross domestic product (GDP). In many cases, coal combustors have no pollution controls. Moreover, most have relatively low stacks and release emissions relatively close to the ground, further aggravating the problem. The result is that concentrations of airborne dust have been found to be many times higher than the maximum safe level.

The City of Krakow, one of the world's greal cultural centers, has a serious problem with airbome pollutants. These emissions are discharged from stacks burning coal, mainly unwashed. This paper discusses one of the projects initiated by the U.S.Department of Energy for environmental cleanup in Krakow. This particular project involves an efficient control technology for mitigation of particulate emissions. The technology is referred to as the Core Separator, and it has been under development by LSR Technologies, Inc. in the U.S.A.

\section{Environmental Conditions in Krakow}

During a visit to Poland a few years ago, former President Bush stated, "Today Krakow is under siege by pollutants. Its priceless monumenis are being destroyed."
The destruction is caused primarily by airborne pollutants emanating from the combustion of hard coal and coke in so called Low Emission Sources(LES). Fossil fuels are used heavily for heating purposes during the winter season. The 750000 population in Krakow relies heavily on hard coal as the heating source. About $35 \%$ of the heating needs is provided by some 2900 local boilers, often with low efficiency cyclones for particulate removal and no sulfur abatement technologies. These boilers consume yearly an estimated 370000 tonnes of coal and coke. As a result, the combination of coal combustion and the city's location in a valley having a temperature inversion, quite often a heavy suspended smog is visible over Krakow.

A major portion of heating needs is provided by district heating supplied with heat from local power plants, Leg and Skawina. These plants have high stacks that dilute and distribute pollutants over large areas. The primary cause of low ambient air quality in Krakow is from suspended particles and $\mathrm{SO}_{2}$ emissions. $\mathrm{SO}_{2}$ pollution is generated to a large extent (some $47 \%$ ) from the neighboring Upper Silesian Industrial Region, while the balance comes from Krakow industry and power sectors (some $18 \%$ ) and Low Emission Sources (35\%). The picture is, however, quite different with particulate matler. Low Emission Sources are almost entirely responsible for suspended particulate matter in the ambient air in Krakow.

By definition "suspended particles" are referred to as particles of dust with a size less than $10 \mu \mathrm{m}$ in diameter that do not fall to the ground from the force of gravity. These particles are in the respirable range, i.e., they have potential for accumulating in the lungs of humans causing respiratory disease.

Krakow air is continuously measured by a network of Automatic Ambient Air Monitoring Stations. The instantancous/real time concentrations of $\mathrm{SO}_{2}, \mathrm{CO}$, suspended dust, and $\mathrm{NO}_{2}$ in the ambient air are monitored continuously. The 30 -minute $\left(D_{30}\right)$ and daily $\left(D_{24}\right)$ average concentrations for each pollutant are plotted and tabulated. From this, the actual pollutant measurements can be compared with permissible values. According to Polish Law, Krakow is located in a "protected area." For designated protected areas, the permissible concentrations of the main air pollutants are given in Table 1 . 
Table 1 Allowable Concentrations- Pollutants in Ambient Air Protected ìreas of Poland

\begin{tabular}{|c|c|c|}
\hline Pollutant & $\begin{array}{c}\text { 30-Minutc } \\
\text { Concentration } \\
\mathrm{D}_{30} \mu \mathrm{g} / \mathrm{m}^{3}\end{array}$ & $\begin{array}{c}\text { Daily Average } \\
\text { Concentration } \\
\mathrm{D}_{24} \mu \mathrm{g} / \mathrm{m}^{3}\end{array}$ \\
\hline $\mathrm{SO}_{2}$ & 600 & 200 \\
\hline $\mathrm{NO}_{2}$ & 500 & 150 \\
\hline $\mathrm{CO}$ & 5000 & 1000 \\
\hline $\begin{array}{c}\text { Suspended } \\
\text { Particles }\end{array}$ & 250 & 120 \\
\hline $\mathrm{O}_{3}$ & 100 & 30 \\
\hline
\end{tabular}

It is of particular interest to compare measurements of suspended particulate concentrations in both the winter and summer seasons. Figures 1 and 2 show measurements taken at one monitoring station ir 3 bruary 1993 and in July/August 1993. In these figures, it is immediately apparent that: (1) concentrations are significantly higher in winter during the heating season, and (2) concentrations in wintertime very often exceed the permissible values from Table 1.

The same correlation can be observed in other air pollutants from coal combustion such as sulphur dioxide and carbon monoxide. The conclusion in each case is unmistakable, that Low Emission Sources used during the heating season are responsibic for this situation.

\section{Abatement Options for Dust Emissions}

In order to improve ambient air quality in Krakow, the discharge of emissions during the lieating season must be reduced. There are several ways to limit particulate emissions from LES. Conversion of coal/coke boilers to natural gas and connection of some heated areas to the district heating network are a couple of examples. Also in this category are improvements in energy saving measures in buildings, which would reduce sol consumption. In the long run though, it is unlikely that coal combustion in local boilerhouses in Krakow will be entirely eliminated. The Ordinance of the Polish Ministry of Environmental Protection of February 12, 1990 on Protection of Air Against Pollution gives allowable emissions for combustion sources. The values are quite stringent $(600 \mathrm{~g} / \mathrm{GJ}$ of fuel input for uravelling grate boilers fired with hard coal), and much lower for coke and other firing systems. The deadline to comply with these limits was set for the beginning of 1998 . In addition, the local voivod environmental standards will likely be even more stringent than that of the Polish Ministry. Existing pollution control equipment (mainly cyclones) is not likely to meet future regulations for dust mitigation in Krakow. Utilization of smokeless fuel or bag filters are possible options, but both are rather costly. The novel Core Separator technology developed by LSR Technologies can moet these regulations for either new or existing boilers. This technology will be described in more detail in the following section.

Monthly Suspended Dust Concentrations

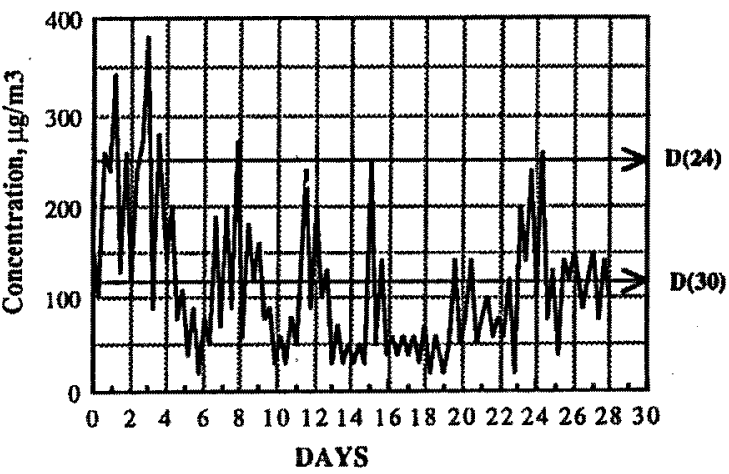

Fig.1 Transient Concentrations - Suspended Air, $\mu \mathrm{g} / \mathrm{m3}$ Krakow February 1993

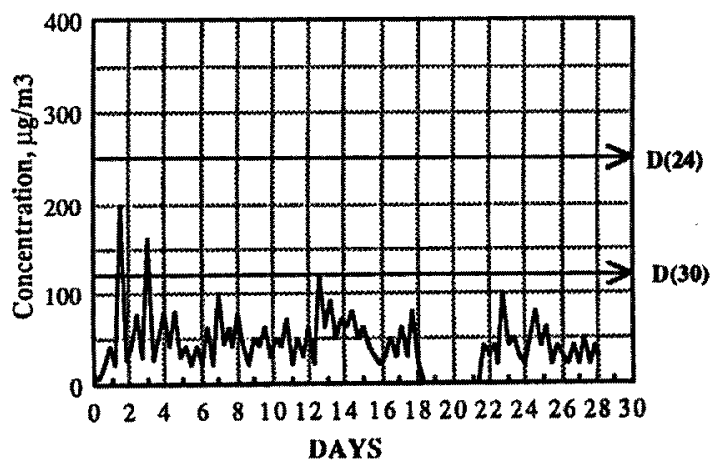

Fig. 2 Transient Concentrations - Suspended Air, $\mu \mathrm{g} / \mathrm{m} 3$ Krakow July/August 1993 


\section{Principle of Operation}

The Core Separator is one of very few advances made in the field of particulate control in recent years. The lechnology was developed through research sponsored by the U.S. Department of Energy and Environmental Protection Agency. A number of these units have been placed in operation in the U.S. All of the units now in service are performing very difficult separations, i.e., those involving dust particles with small aerodynamic diameters. More recently, license agreements have been completed with firms in the U.K. and Australia.

Historically, mechanical separators have been incfrective in removing dust particles with diameters below 10 microns. In comparison, the Core Separator is able to remove a high percentage of particles even at $2-3$ microns in diameter. This is roughly equivalent to the performance of a medium-efficiency clectrostatic precipitator (ESP). Figure 3, which was created by Industrial Filter \& Pump Mrg. Co., illustrates the relative performance of several particulate control devices including cyclones, barrier filters, ESPS and wet scrubbers. The Core Separaior performance is also superimposed on this figure. As illustrated, its performance is comparable to a medium-efficiency ESP or a high-energy venturi scrubber. Yet, the Core Separator still has the traditional advanlages of mechanical collectors such as simplicity, reliability, compactness, and low maintenance.

A simplificd schematic of the Core Separator system is shown in Figure 4 . The system includes two conventional components, a cyclone collector for extracting solids and a fan for flow recirculation. The Core Separator is actually a multitude of cylindrical units. Each unit has a single inlet for the stream to be treated and two outlels, one for the cleaned gas stream and the other containing a highly concentrated recirculation stream. The dust-laden recirculation stream is fed to the cyclone and then returns again by means of the fan. The processes of separation and collection are accomplished separately in different components. The Core Separator cleans the inlet stream and detains dust particles in the system. Since its efficiency is quite high, the dust particles cannot leave the system. They recirculate again and again until collected in the cyclone.

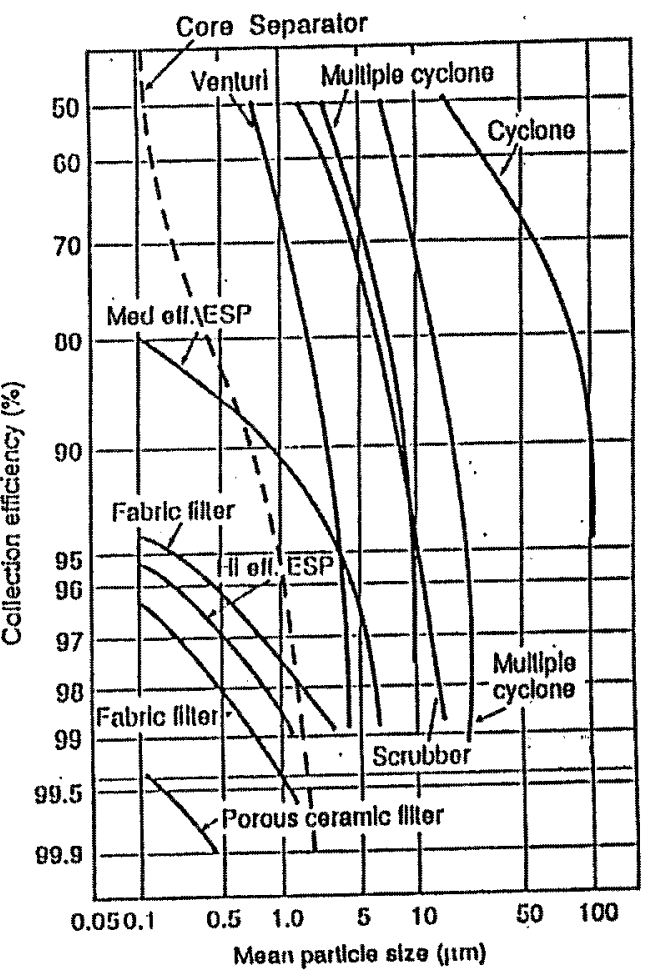

Fig.3 Particle Collector Performance (Printed with permission of Industrial Filter \& Pump Mfg. Co.) 


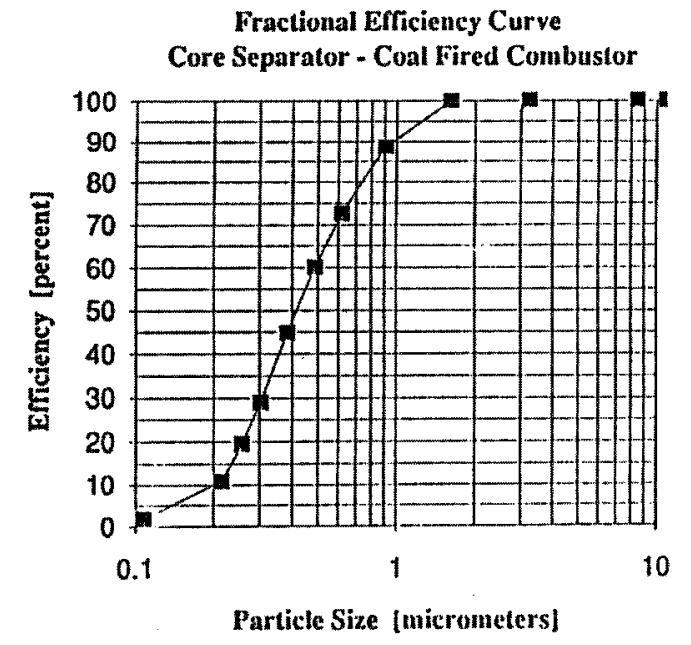

Currently, particulate control devices can be grouped into four(4) different categories: electrostatic precipitators, fabric filters, wet scrubbers, and incclianical collectors. The Core Separator is actually an advanced high performance mechanical collector. However, for the sake of comparison, it will be considered as a separate calcgory.

In Table 2, many features used in the purchasing decision for this equipment are compared. The features of the Core Separator are highly dirferentiated from other methods of particulate control as shown in this table. Mechanical collectors are currently used to remove coarse particles ( $>10$ microns in diameter). They are preferred in this application since they require low capital and operating expenditures. However, mechanical collectors are inefficient in the removal of small particles $(<10$ microns), sometimes referred to as "respirable particulates".
These particles are typically separated in a final stage by electrostatic precipitators, fabric filters, or in some cases, wet scrubbers. Each of these are high cost devices. As shown in Table 2, the Core Separator compares quite favorably against other devices in terms of fine particle performance. Also, it has most other attributes of mechanical collectors, making it highly desirable in dust collection applications.

The Core Separator has been under devclopment since 1989. During its research, numerous laboratory and field prototypes were built and tested. As noted earlier, the Riley Stoker Corporation installed a Core Separator unit to remove flyash from their PC-fired Combustor Test Facility. Test results conducted by Rilcy Research showed the particulate removal efficiency of the Core Separator to range between 95 and $98 \%$ over a series of several controlled tests.

Several Core Separator units have also been sold on a commercial basis in the U.S. and abroad. These units range in size from 850 to $11,900 \mathrm{NM}^{3} / \mathrm{h}(500-7,000$ ACFM) and each perform difficult separations, i.e., those removing dust particles with small aerodynamic diameters. The boiler houses in Krakow are of a comparable scale to the Core Separator units currently in operation. Therefore, the only significant development issues and technology unknowns are as follows:

(1) Performance with Polish Coals

(2) Pcrformance with Crushed Coal Fecd Systems

Through this project and with the assistance of the Department of Energy, six demonstration units will be placed in operation in the City of Krakow during 19941995. These units will demonstrate performance of this tcchnology with different Polish coals and firing systems.

Table 2- Characteristics of Particulate Control Devioes

\begin{tabular}{|c|c|c|c|c|c|}
\hline FEATURE & $\begin{array}{l}\text { ELECTROSTATIC } \\
\text { PRECIMTATORS }\end{array}$ & $\begin{array}{l}\text { FABRIC } \\
\text { FILTERS } \\
\end{array}$ & $\begin{array}{c}\text { CYCLONE } \\
\text { COLLECTOKS }\end{array}$ & $\begin{array}{c}\text { WET } \\
\text { SCRUBnERS }\end{array}$ & 40 \\
\hline COLLECTION EFFICIENCY & HIGH & HIGH & Low & HIGH & HIGH \\
\hline CAPABILITY FOR HIGH SOLIDS LOADING & No & No & YES & NO & YES \\
\hline PRESSURE DROP & VERY LOW & LOW.MED. & LOW-MED. & MED.HIGH & LOW-MED. \\
\hline CAPITAL COST & VERY HIIGII & $\mathrm{HCH}$ & Low & HIGII & LOW-MED. \\
\hline OPERATING COST & HIGH & HICH & Low & MED.HILH & Low \\
\hline HIGH TEMP.PRESS.CAPABILITY & YES & No & YES & NO & YES \\
\hline SPACE REQUIREMENTS & BIGH & HIGH & Low & MEDIUM & Low \\
\hline DIFFICULTY WTTH CERTAIN SUISTANCES & SOME & SOME & NONE & NONE & NONE \\
\hline EXPLOSION,FIRE, OR VOLTAGE HAZARIIS & YES & YES & No & No & No \\
\hline SPECIAL MAINTENANCE REQUIREMENTS & YES & YES & No & No & No \\
\hline OZONE PRODUCED & YES & No & No & No & No \\
\hline WASTEWATER TREA & No & No & No & YES & No \\
\hline
\end{tabular}




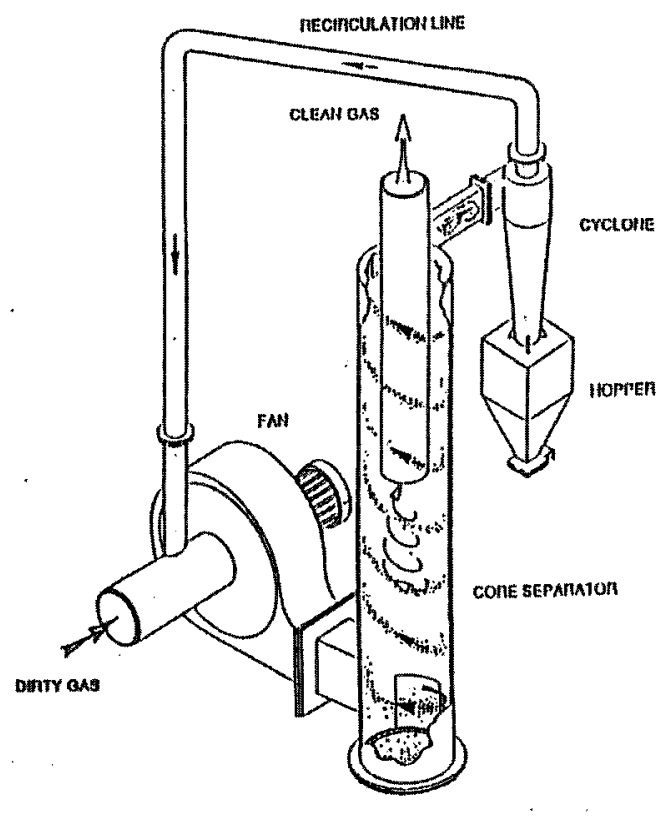

Fig.4 Simplified Arrangement - Core Separator

Two factors govern the performance of Core Separalor systems: (1) a high separation efficiency of the Core Separator component, and (2) an interaction between individual components. To achieve high separation efficiency, a proper blecd llow value (ratio of the recirculation flow to the total flow) is requircd. By controlling bleed flow in the Core Separator, the tangential and radial velocitics can be controlled independently to maintain them in the sicsirable rangc.

High efficiency in the Core Separator is due to low particle reentrainment. In this regard, the system is designed in such a way as to avoid formation of toroidal vortices. The Core Separator component functions as a scparator, but not as a solids collector. This permits the avoldance of a flow U-turn within the device. It has a cylindrical shape, and surfaces promoting formation of vortices are moved away from the clean flow outlet. It should be pointed out that all these factors work together, and taken individually cannot prevent vorticity.
The separation efriciency of the Core Separator actually predetermines the efficiency of the system even if the collector efficiency if relatively low. The following formula can be used to calculate partial collection efficiency when the collector is situated downstream of the Core Sejurator.

$$
E_{a y t}=\frac{E_{a} \times E_{c y c}}{1-E_{c s}\left(1-E_{c y c}\right)}
$$

When the collector is situated upstream of the Core Separator,

$$
E_{x y s}=\frac{E_{c y c}}{1-E_{c t}\left(1-E_{c y c}\right)}
$$

Here $\mathrm{E}_{\mathrm{cs}}, \mathrm{E}_{\mathrm{cyc}}$ and $\mathrm{E}_{\mathrm{sys}}$ relate to the Core Separator, collcctor and Core Separator system partial separation efficiencies, resjectively.

The Core Separalor System can actually be arrauged in a varicty of configurations depending on process conditions, required performance, inlct dust concentration, abrasiveness of solids, etc. A single fan arrangement is the lowest cost design and can be used in most coal-fired boiler applications.

The Core Separator has been tested on the effluent stream from a pulverized coal-fired combustor. The site selected for this work was the Pilot Scale Combustor Test Facility owncd and operated by the Riley Stoker Corporation, a major U.S. boiler manufacturer. Riley Research performed many tosts to evaluate Core Separator performance in semoving fine particulate matter in the combustor off-gas. A high volatile Eastern Bituminous coal from West Virginia was used to fuel the Combustor Test Facility and generate a typical flue gas condition (ic., 150-200 deg. C). This testing showed that particle retention under controlled test conditions ranged from 95 to $98 \%$. This performance is actually higher than that of some ESP units under similar conditions. The cut point diameter $\left(d_{50}\right)$ in these tests was consistently found to be below $0.5 \mu \mathrm{m}$, and the particle outlet concentration from the Core Separator was in some cases less than 100 $\mathrm{mg} / \mathrm{M}^{3}$. A fractional separation efriciency curve was produced with data taken by Riley Research is shown in Figure 5. 
Emissions Reduction Potential and Impact on Heating Cost

The City of Krakow has about 1300 boiler houses providing heat for industrial, commercial, and residential use. The boiler houses contain about 2250 boilers, some with no emission controls at all. Many boilers are equipped with cyclone collectors, which remove roughly $80 \%$ of the total particulate emissions. High cfficiency collectors such as bagfilter units and electrostatic precipitators are practically non-existent due to their high cost and maintenance requirements.

The cost of emission reduction options requires careful analysis, and it is unlikely that any one option is best in all cases. In this section, attention will focus on ways to modernize boiler houses through the addition of particulate control equipment. The choices include:

- Addition of Cyclone Collectors

- Addition of Bagfilier Units

- Addition of Core Separator Systems

A cost analysis was performed based on data for particulate control equipment sold in the U.S. Table 3 provides a cost comparison of cyclones, pulse-jet bagfilters, reverse-air bagfilters, and the Core Separalor. Cost data for the Core Separator was based on historical costs, whereas data for cyclones and bagfilters were based on recently completed studies by the Electric Power Research Institute (EPRI). The capacities shown in this table are typical of boiler capacities throughout the City of Krakow.

It is also interesting to compare the cost and respective benefit of each of these alternatives. As shown in Table 4, conventional cyclones provide the lowest cost per ton of pollutant removal. However, this criterion is not normally used in the U.S. or EC nations, since (1) cyclones cannot meet most regulatory standards, and (2) the incremental cost of higher efficiency increases sharply. For this reason, the penctration of the pollutant into the atmosphere is more meaningful. Such a comparison reveals that the Core Separator costs a litule more than twice that of an equivalent sized cyclone, but allows only about $1 / 5$ of the total penetration of solids to the atmosphere. The Core Separator also has the ability to meet future emission standards in Poland, which may not te widhin reach of cyclones.
The addition of any emission control cquipment will involve some parasitic losses which must be factored into the total heating cost. For the Core Separator, the draft loss through the system is reflected in the power for the recirculation fan which is ultimately part of the operating cost. It has been demonstrated that the operating cost of the Core Separator is less than $1.0 \%$ of the boiler thermal input. And, unlike ESPs and fabric filters, maintenance costs are almost non-existent.

The Core Separator is very well suited to the LES sources of particulate cmissions in Krakow. It is unique in that it has the following altributes:

(1) Cost-effectiveness even at boiler capacitics below $500 \mathrm{kw}$

(2) Efficient in removing respirable $\left(\mathrm{PM}_{10}\right)$ particles

In recent years, particulate emissions have been the largest component of the air pollution control market, claiming well over $60 \%$ of annual expenditures. In addition to the 1300 boiler houses in the City of Krakow, the region also has many other industries requiring fine particle control equipment. The following industries require such equipment:

$\begin{array}{ll}\text { CombustorFlyash } & \text { Hazardous Waste } \\ \text { Smelters } & \text { Incineration } \\ \text { Sinter Dusts } & \text { Sludge Incincration } \\ \text { Crushers } & \text { Waste Heat Boilers } \\ \text { Iron Ore } & \text { Saw Dust } \\ \text { Gypsum } & \text { Roasting } \\ \text { Fiberglass Dust } & \text { Catalyst Recovery } \\ \text { Pulp \& Paper } & \text { Paints \& Pigments } \\ \text { Pharmaceuticals } & \text { Coal Preparation } \\ \text { Asphalt Plants } & \text { Fertilizer Dusts } \\ \text { Fumaces } & \text { Cement Kilns } \\ \text { Solid Waste Recycling } & \text { Plastics Processing } \\ \text { Cereal/Grain } & \text { Lime/Limostone Dust } \\ \text { Glass Mclting } & \text { Stone Dusts }\end{array}$

Thermal Driers 
Table 3 Total Installed Cost - Particulate Control Devices

\begin{tabular}{|c|c|c|c|c|c|}
\hline \multicolumn{2}{|c|}{ Size or Capacity } & \multicolumn{4}{|c|}{ Device Type } \\
\hline $\begin{array}{c}\text { Gas Flow } \\
\mathrm{M} 3 / \mathrm{h}\end{array}$ & $\begin{array}{c}\text { Thermal Inpu! } \\
\mathrm{KW}\end{array}$ & $\begin{array}{c}\text { Cyclone } \\
\$ /(\mathrm{M} 3 / \mathrm{h})[\$ / \mathrm{KW}]\end{array}$ & $\begin{array}{l}\text { Pulse Jet Baghouse } \\
\$ /(\mathrm{M} 3 / \mathrm{M})[\$ / \mathrm{KW}]\end{array}$ & $\begin{array}{l}\text { Reverse Air Baghouse } \\
\$ /(\mathrm{M} 3 / \mathrm{h})[\$ / \mathrm{KW}]\end{array}$ & 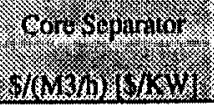 \\
\hline 2,000 & 402 & $0.99[4.90]$ & $14.52[72.16]$ & $22.47[1111.69]$ & $2.47[12.28]$ \\
\hline 5,000 & 1007 & $0.90[4.47]$ & $11.69[58.06]$ & $18.10[89.86]$ & $2.36[11.71]$ \\
\hline 10,000 & 2,012 & $0.84[4.18]$ & $9.93[49.36]$ & $15.37[76.39]$ & $2.28[11.32]$ \\
\hline 15,000 & 3,018 & $0.79[3.92]$ & $8.43[41.90]$ & $13.05[64.85]$ & $2.20[10.93]$ \\
\hline 25,000 & 5,030 & $0.76[3.77]$ & $7.66[38.07]$ & $11.85[58.91]$ & $2.16[10.73]$ \\
\hline
\end{tabular}

Basis: (1) Boiler Heat Rate $3 ! 50 \mathrm{Kcal} / \mathrm{KWH}$

(2) Baghouse Data "Sloat, D.G., et al 1991 EPRI Particulate Control Symposium

(3) Cyclone Data "Vatavuk, W.M., Chemical Enginecring, May 1990

(4) Core Separator Data from Historic Costs

Table 4

Cost/Benefit Comparison - Particulate Control Equipment

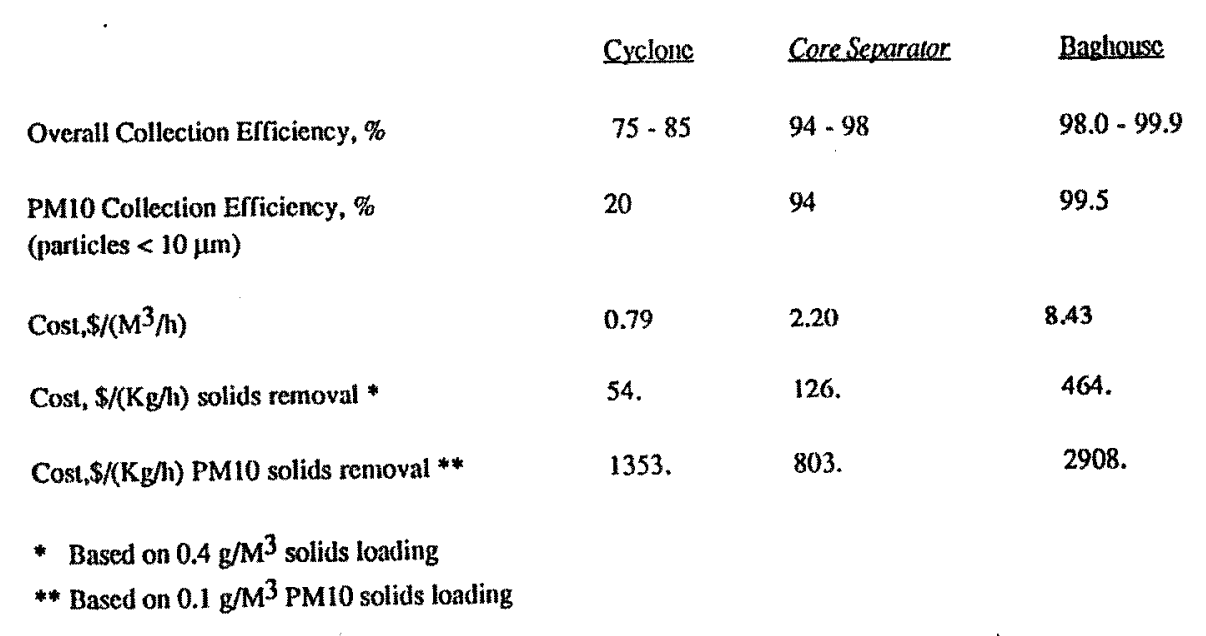




\section{Conclusion}

The U.S. and Polish Bilateral Steering Committee with the assistance of DOE contractors bave identified specific methods to improve air quality and reduce emissions throughout the city. These include:

- Extensions to the district heating system, which could eliminate many small uncontrolled boilers

- Conversion of hand-fired boilers to natural gas

- Elimination of home stoves in selected parts of the city

- Use of improved home stove designs

- Modernization of boiler houses to reduce emissions

This project addresses modernization of boiler houses through the application of ncw technology recently developed in the U.S. For particulate emissions. The technology is well-suited to the industrial size boilers located in Southern Poland and is capable of removing dust particles below 10 microns in diameter, the so called PM-10 emissions. Its performance is almost as good as ESPs and fabric filters, but without the attendant cost and maintenance. In small boiler applications such as those in Central Europe, it may be the Best Available Control Technology (BACT).

\section{Acknowledgement}

The authors would like to thank Mr. Douglas Gyorke for his guidance in preparing this paper and the Department of Energy for supporting this important project.

\section{References}

Informacja $\mathrm{nr} 2 / 93$ i $\mathrm{nr} 7-8 / 93$ o poziomic zanieczyszczenia powietrza w lutym i lipcu/sicrpniu 1993

w Krakowie. Publication of Environmental Protection Office at Krakow Voivodship.

Ordinance of the Ministry of Environmental Protection Natural Resources and Forestry of 12th February 1990 on Protection of Air Against Pollution. Poland.

Priorytetowe Kicrunki Eliminowania Zanieczyszczen Powietrza Atmosferycznego Spowodowanych zrodlami Niskiej Emisji Na Terenie Krakowa. Krakow Luty 1991. Krakow Development Office Publication by Janusz Bardcl, Jan Bieda and others.
Personal Communication with Janusz Bardel from Krakow Development Office, 1994.

Zievers, James F., Zievers Elizabeth C. and Eggerstedt, Paul, "Porous Ceramics for Gas Filuration," Ceramic Bulletin, Vol. 70, No. 1. 1991.

Pierce, Barbara L. and Butcher, Thomas A., "Krakow Clean Fossil Fuels and Energy Efriciency Project," Ninth Annual Coal Preparation, Utilization, and Environmental Control Contractors Conference, U.S. Dept. of Energy, July 19-22, 1993.

Smolensky, L.A., Easom, B.H. and Wysk S.R., "A Core Separator System for Fine Particulate Removal," Eighth Amnual Coal Preparation. Utilization, and Environmental Control Contractors Conference, U.S. Dept. of Energy, July 27-30, 1992.

Smolensky, L.A., Wysk, S.R. and Murison, A., "Novel Particulate Control for Industrial Gas Cleaning," Filtration and Separation, January/February 1993 